\title{
Development of a Fissile Particle for HTGR Fuel Recycle
}

\author{
F. J. Homan \\ E. L. Long, J r. \\ T. B. Lindemer \\ R. L. Beatty \\ T. N. Tiegs
}

\section{MASTER}

\section{OAK RIDGE NATIONAL LABORATORY}

OPERATED BY UNION CARBIDE CORPORATION FOR THE ENERGY RESEARCH AND DEVELOPMENT ADMINISTRATION 


\section{DISCLAIMER}

This report was prepared as an account of work sponsored by an agency of the United States Government. Neither the United States Government nor any agency Thereof, nor any of their employees, makes any warranty, express or implied, or assumes any legal liability or responsibility for the accuracy, completeness, or usefulness of any information, apparatus, product, or process disclosed, or represents that its use would not infringe privately owned rights. Reference herein to any specific commercial product, process, or service by trade name, trademark, manufacturer, or otherwise does not necessarily constitute or imply its endorsement, recommendation, or favoring by the United States Government or any agency thereof. The views and opinions of authors expressed herein do not necessarily state or reflect those of the United States Government or any agency thereof. 


\section{DISCLAIMER}

Portions of this document may be illegible in electronic image products. Images are produced from the best available original document. 
Printed in the United States of America. Available from National Technical Information Service

U.S. Department of Commerce 5285 Port Royal Road, Springfield, Virginia 22161

Price: Printed Copy $\$ 4.50 ;$ | Microfiche $\$ 3.00$

This report was prepared as an account of work sponsored by the United States Government. Neither the United States nor the Energy Research and Development Administration/United States Nuclear Regulatory Commission, nor any of their employees, nor any of their contractors, subcontractors, or their employees, makes any warranty, express or implied, or assumes any legal liability or responsibility for the accuracy, completeness or usefulness of any information, apparatus, product or process disclosed, or represents that its use would not infringe privately owned rights. 
ORNL/TM-5602

Distribution

Category UC-77

Contract No. W-7405-eng-26
METALS AND CERAMICS DIVISION

HTGR BASE TECHNOLOGY PROGRAM

Fueled Graphite Development (189a OHOO2)

DEVELOPMENT OF A FISSILE PARTICLE FOR HTGR FUEL RECYCLE

F. J. Homan, E. L. Long, Jr., T. B. Lindemer,

R. L. Beatty, and T. N. Tiegs

Date Published: December 1976

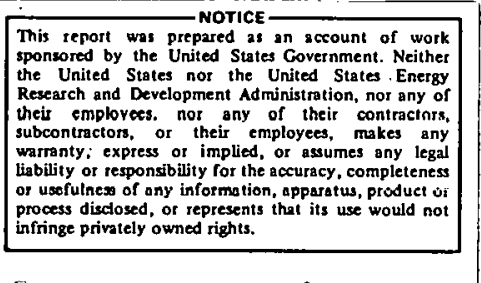

NOTICE This document contains information of a preliminary nature. It is subject to revision or correction and therefore does not represent a final report.

OAK RIDGE NATIONAL LABORATORY

Oak Ridge, T'ennessee 37830

operated by

UNION CARBIDE CORPORATION

for the

ENERGY RESEARCH AND DEVELOPMENT ADMINISTRATION 


\section{THIS PAGE}

\section{WAS INTENTIONALLY \\ LEFT BLANK}


CONTENTS

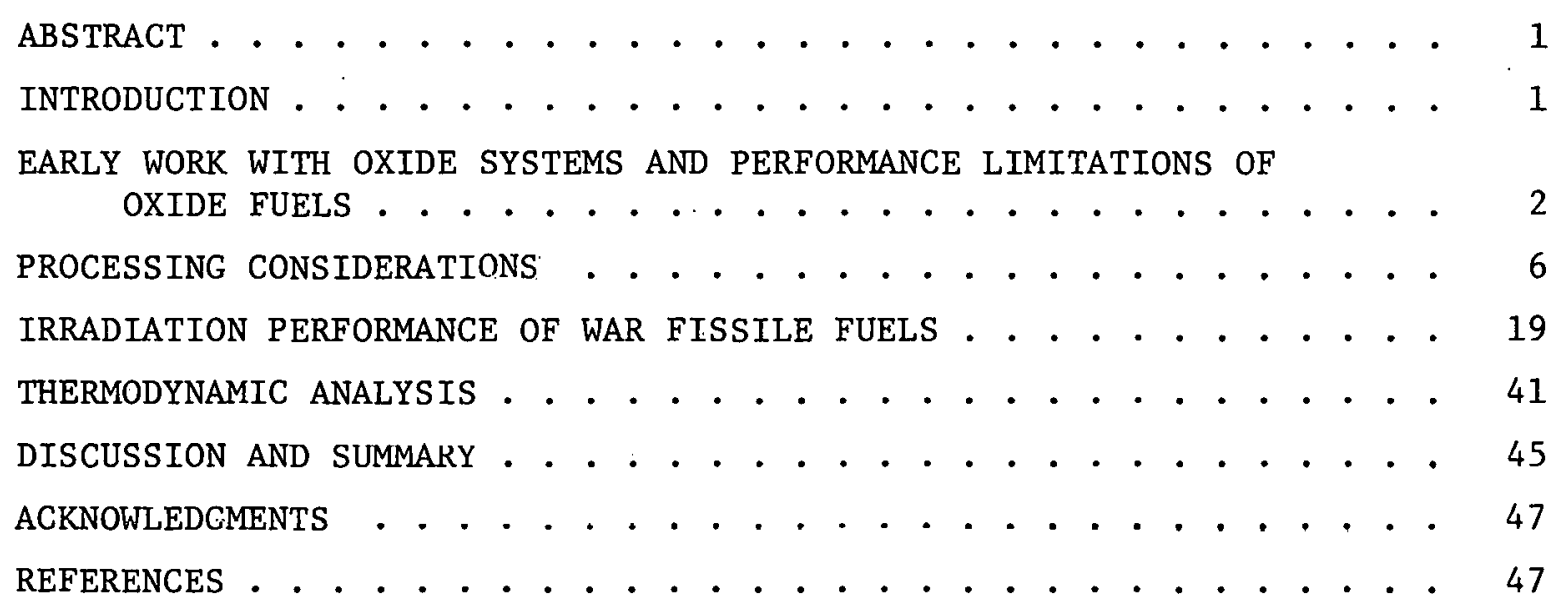




\title{
DEVELOPMENT OF A FISSILE PARTICLE FOR HTGR FUEL RECYCLE
}

\author{
F. J. Homan, E. L. Long, Jr., T. B. Lindemer, *
}

R. L. Beatty, and T. N. Tiegs

\begin{abstract}
Recycle fissile fuel particles for high-temperature gascooled reactors (HTGRs) have been under development since the mid-1960s. Irradiation performance on early $\mathrm{UO}_{2}$ and $\mathrm{Th}_{0 .}{ }_{8} \mathrm{U}_{0} .{ }_{2} \mathrm{O}_{2}$ kernels is described in this report, and the performance limitations associated with the dense oxide kernels are presented. The development of the new reference fuel kernel, the weak-acidresin-derived (WAR) $\mathrm{UO}_{2}-\mathrm{UC}_{2}$, is discussed in detail, including an extensive section on the irradiation performance of this fuel in HFIR removable beryllium capsules HRB-7 through -10 .

The conclusion is reached that the irradiation performance of the WAR fissile fuel kernel is better than that of any coated particle fuel yet tested. Further, the present fissile kernel is adequate for steam cycle HTGRs as well as for many advanced applications such as gas turbine and process heat HTGRs. It is emphasized that throughout this report "fuel" is used in the narrow sense to mean coated particles only, not fuel rods and.. fuel elements. Further, this report concentrates on kernel. development and does not discuss the development associated with the various coating layers on the recycle fissile fuel particle.
\end{abstract}

\section{INTRODUCTION}

Irradiation testing of coated particle fuels has been in progress at ORNL since the mid-1960s. ${ }^{1}$ Early work on recycle fuel development was concentrated on oxide systems, because the more difficult fabrication processes associated with the carbide systems are not easily adapted to the remote operation required for fabrication of recycle fuels.

The first candidate recycle fuel for the high-temperature gascooled reactor (HTGR) was $\mathrm{UO}_{2}$. Early irradiation testing of $\mathrm{UO}_{2}$ identified a severe problem with thermal migration of the $\mathrm{UO}_{2}$ kernel up the temperature gradient (amoeba), and through the coating layers. The candidate fertile fuel for recycle application has always been $\mathrm{ThO}_{2}$. The acceptable performance of. $\mathrm{ThO}_{2}$ relative to $\mathrm{UO}_{2}$ suggested

*Chemical Technology Division. 
dilution of the fissile particle with fertile material. Thus, Tho. ${ }_{8} \mathrm{U}_{0.2} \mathrm{O}_{2}$ became the reference recycle fuel and was extensively tested. The irradiation tests showed that the thermal stability of $\mathrm{Th}_{0} ._{8} \mathrm{U}_{0}{ }_{2} \mathrm{O}_{2}$ was marginal. Higher Th/U ratios were briefly considered for the recycle fissile particle, including $T h / U=8$, the maximum dilution possible as it is the overall $\mathrm{Th} / \mathrm{U}$ ratio in the recycle element. These fuels did not show any decrease in thermal migration rate over the reference $\mathrm{Th}_{0.8} \mathrm{U}_{0 .} \mathrm{O}_{2}$ fuel.

While the Tho, ${ }_{0} \mathrm{U}_{0}{ }_{2} \mathrm{O}_{2}$ kernels were being irradiation tested under the Thorium Utilization Program, an effort to develop alternate fissile fuels was in progress at ORNL under the HTGR Base Program. One fuel that appeared to have promise was an undiluted fissile fuel derived by loading weak-acid ion exchange resins with uranium from a solution. This weak-acid resin (WAR) fuel had been tested in several irradiation capsules and had performed we11. Besides the superior irradiation performance relative to the $\mathrm{Th}_{0 .}{ }_{8} \mathrm{U}_{0 .}{ }_{2} \mathrm{O}_{2}$ fuel, there appeared to be some cost advantages to an undiluted fissile fuel; consequently the WAR particle became the reference fissile recycle particle. Additional irradiation testing has confirmed its superiority and has suggested that the WAR fissile fuel may be adequate for use in advanced HTGR applications such as the gas turbine and process heat applications.

The potential cost advantages mentioned above are mainly due to the reduced amount of heavy metal that must be processed in the remotely operated equipment of the refabrication facility. Refabrication of mixed-oxide fuel with $\mathrm{Th} / \mathrm{U}=4$ would require five times as much heavy metal to be processed in the heavily shielded refabrication facility as would be required by an undiluted fissile particle (like the WAR fuel). The use of an undiluted fissile particle permits the fertile fuel to be processed in a contact facility with the coated fertile particles added to the refabrication stream at the blending step. Thus, the expensive remote kernel preparation and coating steps are required only for the fissile material. With the WAR fuel, many of the size and shape separation operations can be done with the unloaded resin in contact equipment with further cost savings. However, it should be emphasized that the WAR fuel was selected as the recycle reference fissile fuel on the basis of superior irradiation performance. The cost advantages are speculative, and require further evaluation.

\section{EARLY WORK WITH OXIDE SYSTEMS $\Lambda$ ND PERFORMANCE LIMITATIONS OF OXIDE FUELS}

The first candidate recycle fuel for the HTGR was $\mathrm{UO}_{2}$. Early irradiation testing of $\mathrm{UO}_{2}$ showed a severe problem with thermal migration of the $\mathrm{UO}_{2}$ kernel up the temperature gradient (also called the amoeba effect), and through the coating layers (Fig. 1). The temperature and temperature gradient ${ }^{1,2}$ to which these particles were exposed were nearly equivalent to those in the large high-temperature gas-cooled reactor core design (Fig. 2 and Table 1). 

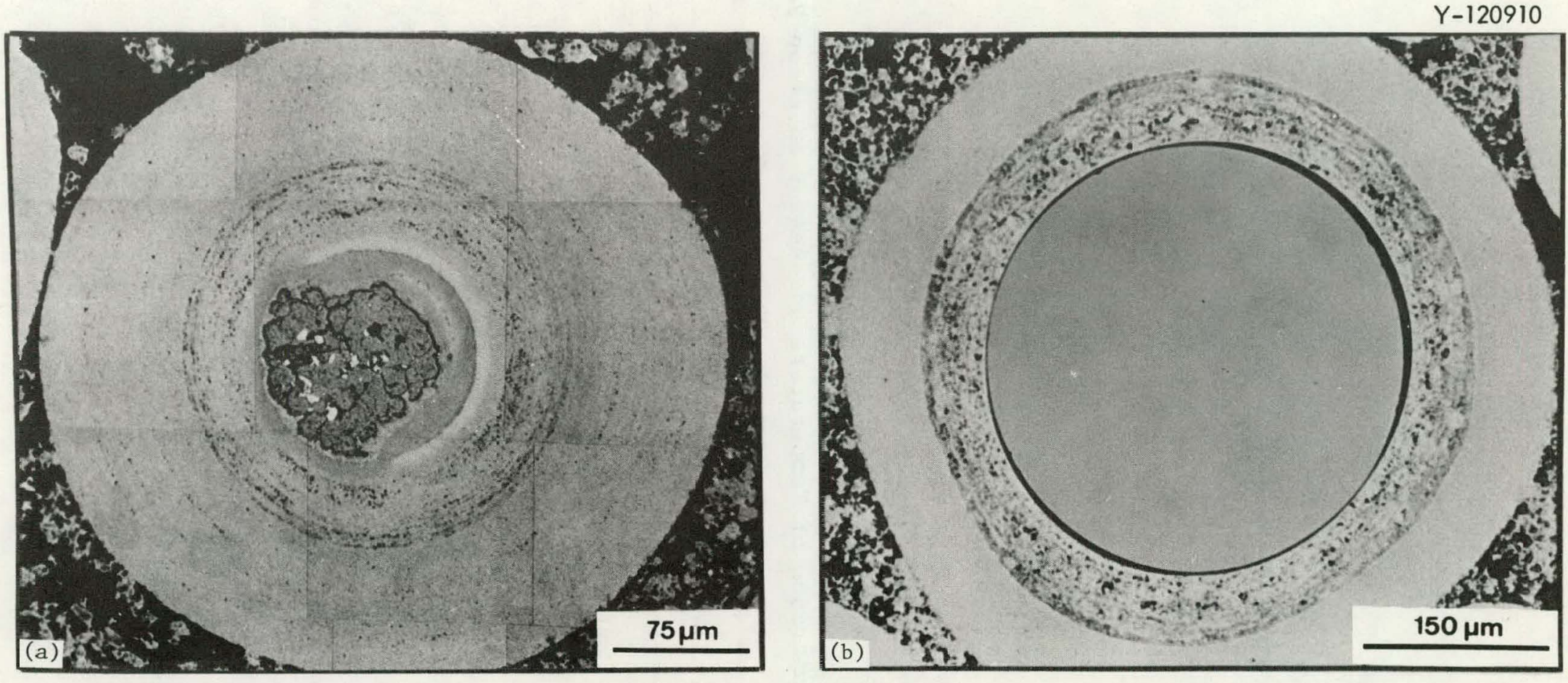

Fig. 1. Relative Thermal Stability of Fissile and Fertile Kernels from Irradiation Test H-1-2. Temperature, $950^{\circ} \mathrm{C}$; thermal gradient, $1000^{\circ} \mathrm{C} / \mathrm{cm}$; fast fluence, $5 \times 10^{21} \mathrm{n} / \mathrm{cm}^{2}$; time at power, 97 days. (a) $\mathrm{UO}_{2}$ (33\% FIMA). (b) $\mathrm{ThO}_{2} \quad(0.2 \%$ FIMA). 


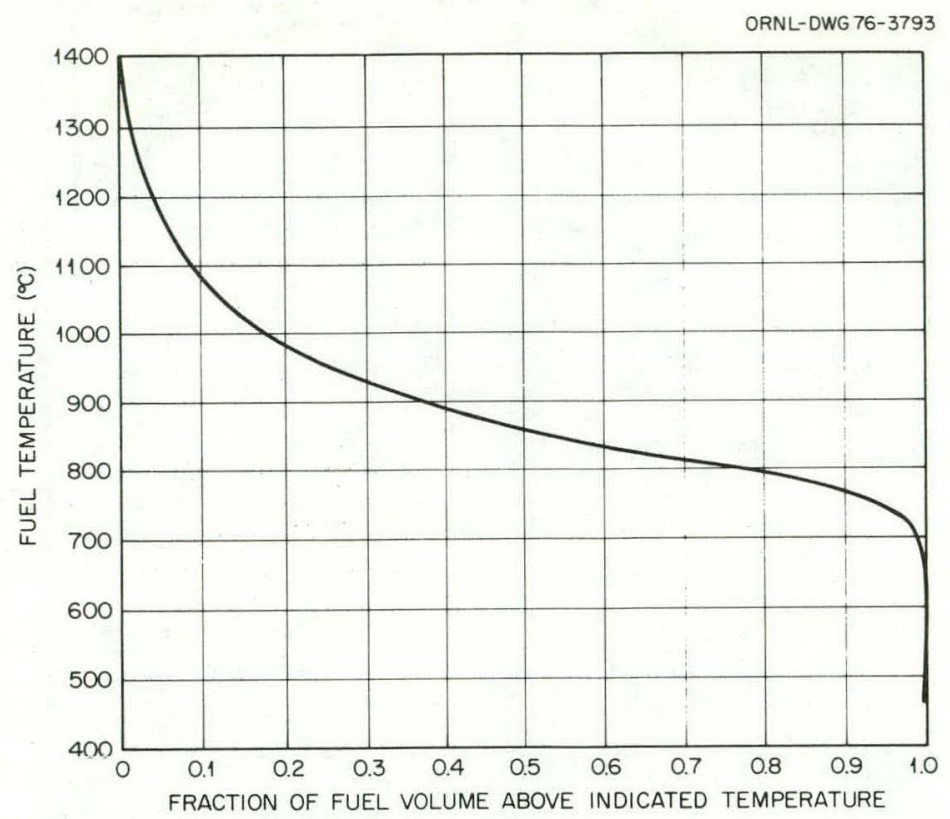

Fig. 2. Fraction of Fuel Operating Above a Given Temperature Under Normal Large HTGR Conditions.

Table 1. Comparison of Temperature and Heat Production Parameters

\begin{tabular}{|c|c|c|c|}
\hline \multirow{2}{*}{ Parameter } & \multicolumn{3}{|c|}{ Reactor } \\
\hline & Fort SL. Vrain & Summit Station & Fulton Station \\
\hline Thermal power, MW & 842 & 2000 & 3000 \\
\hline Power density, kW/1iter & 6.3 & 8.1 & 8.4 \\
\hline \multicolumn{4}{|c|}{ Fuel rod heat rate, $\mathrm{kW} / \mathrm{m}(\mathrm{kW} / \mathrm{ft})$} \\
\hline Average & $3.9(1.2)$ & $7.5(2.3)$ & $7.9(2.4)$ \\
\hline Maximum & $12.4(3.8)$ & $22.3(6.8)$ & $22.9(7.0)$ \\
\hline \multicolumn{4}{|c|}{ Heat flux at coolant holes, $\mathrm{W} / \mathrm{cm}^{2}$} \\
\hline Average & 14.2 & 20.5 & 20.5 \\
\hline Maximum & 44.2 & 57.4 & 58.4 \\
\hline \multicolumn{4}{|l|}{ Fuel temperatures, ${ }^{\circ} \mathrm{C}$} \\
\hline Volume average & 816 & 857 & 890 \\
\hline Maximum (short term) & 1260 & 1420 & 1410 \\
\hline Hot channe1 & & 1585 & 1571 \\
\hline \multicolumn{4}{|l|}{ Graphite temperatures, ${ }^{\circ} \mathrm{C}$} \\
\hline Average & 743 & 777 & 739 \\
\hline Maximum & 1038 & 1121 & 1142 \\
\hline \multicolumn{4}{|c|}{ Temperature gradients, ${ }^{\circ} \mathrm{C} / \mathrm{cm}^{a}$} \\
\hline Average & & 240 & 250 \\
\hline Maximum & & 670 & 700 \\
\hline
\end{tabular}

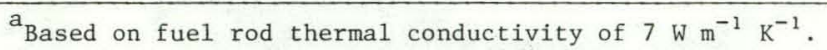


The relative thermal stability of $\mathrm{UO}_{2}$ and $\mathrm{ThO}_{2}$ may be compared (Fig. 1). The subject of thermal migration has been extensively studied and documented in the technical literature ${ }^{3,4}$ and will not be discussed in depth in this report. Only comparisons of the performance of candidate fissile particles for recycle application will be given. Figure 3 compares the average thermal stability of several kernels, among them $\mathrm{UO}_{2}$ and $\mathrm{ThO}_{2}$; the upper and 1ower $90 \%$ confidence limits for the data generally lie half an order of magnitude above and below the average. The crosshatched region and above represents unacceptable performance. This region was determined by calculating the kernel migration coefficients that would lead to migration of the kernel through the buffer layer during normal large HTGR operation. In Fig. 3 the $\mathrm{UO}_{2}$ curve intersects the crosshatched region in the temperature range of primary interest for the large HTGR; whereas the $\mathrm{ThO}_{2}$ curve is well below the crosshatched area for all temperatures of interest. The $\mathrm{UO}_{2}$ kernel was therefore rejected.

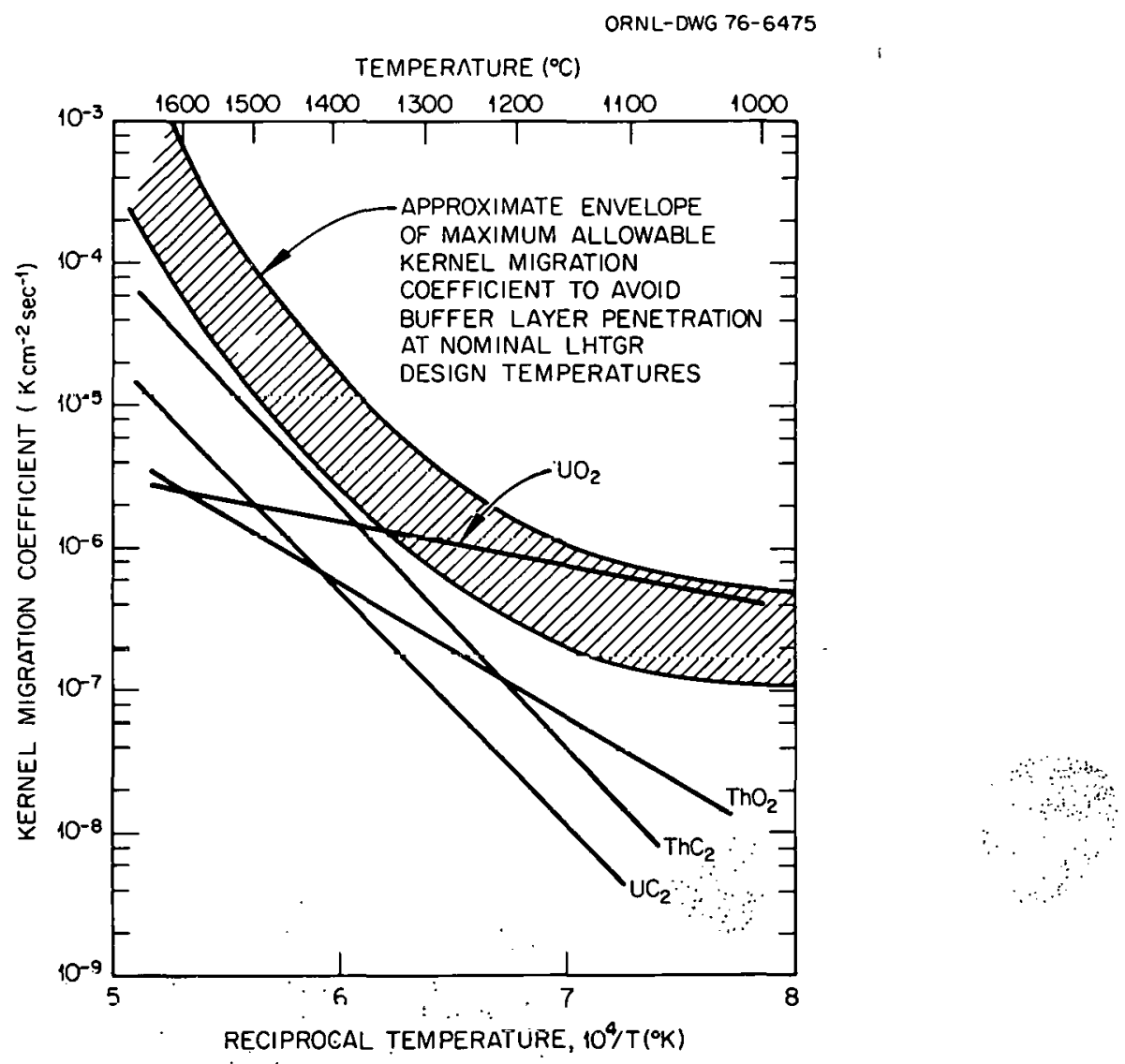

Fig. 3. Average Fuel Kernel Migration Coefficients vs Inverse Temperature Determined from In- and Out-of-Reactor Experiments on Fully Dense Kernels. Source: D. P. Harmon and C. B. Scott, Development and Irradiation Performance of LHTGR Fuel, GA-A131.73 (October 1975), p. 103.

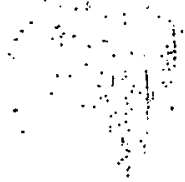


The favorable performance of $\mathrm{ThO}_{2}$ relative to $\mathrm{UO}_{2}$ suggested dilution of $\mathrm{UO}_{2}$ with enough $\mathrm{ThO}_{2}$ to stabilize it. Since the overall $\mathrm{Th} / \mathrm{U}$ ratio in a recycle fuel element is about 8 , there seemed to be considerable latitude. Mixed thorium-uranium oxide in the ratio of about 4 was simple to prepare, and the process was thought to be readily adaptable to the remote operation required in HTGR fuel refabrication. The Tho. ${ }_{8} \mathrm{U}_{0}{ }_{2} \mathrm{O}_{2}$ kernel was selected as the reference recycle fissile fuel ${ }^{5}$ to replace $\mathrm{UO}_{2}$, and an irradiation program tested the new reference fuel (Table 2).

Compositions from $\mathrm{Th} / \mathrm{U}=1$ to $\mathrm{Th} / \mathrm{U}=8$ were tested. Initial impressions at modest irradiation temperatures were encouraging (Fig. 4). ${ }^{6}$ Very little migration of the (Th, U) $\mathrm{O}_{2}$ occurred and, as before, the $\mathrm{ThO}_{2}$ was stable. Unfortunately, at higher operating temperatures the $(\mathrm{Th}, \mathrm{U}) \mathrm{O}_{2}$ was unstable; with the kernel frequently migrating through the coatings (Fig. 5). ${ }^{7}$ A significant amount of irradiation data on dense mixed-oxide kernels has been accumulated (Table 2). These data were treated in similar fashion to the $\mathrm{UO}_{2}$ and $\mathrm{ThO}_{2}$ data (Fig. 3). The results are given in Fig. 6. The average curve for $\mathrm{Th}_{0.8} \mathrm{U}_{0.2} \mathrm{O}_{2}$ falls just at the bottom of the crosshatched critical region, in the range $1100-1400^{\circ} \mathrm{C}$. However, when the $90 \%$ confidence intervals for the thermal migration data are plotted, the upper confidence interval curve extends well into the crosshatched region. This analysis led to the conclusion that this fuel had only marginal thermal stability, so an alternate reference fissile fuel was sought. Additional irradiation testing of other compositions showed little improvement over the reference $(\mathrm{Th} / \mathrm{U}=4)$ system (Fig. 7).8 The thermal stability of the $\mathrm{Th}_{0.89 \mathrm{U}_{0} .11 \mathrm{O}_{2}}$ fuel is about the same as that of the Tho. $8 \mathrm{U}_{0 .} \mathrm{O}_{2}$ fuel. ${ }^{3}$

The fissile particle sclected to replace the dense mixed oxide was an undiluted fissile kernel derived from loading uranium into ionexchange resins from an acid-deficient solution. This weak-acid-resinderived (WAR) fuel will be discussed in detail in the following sections.

\section{PROCESSING CONSIDERATIONS}

The weak-acid-resin-derived (WAR) fissile kernel was selected to replace the $\mathrm{Th}_{0}{ }_{8} \mathrm{U}_{0}{ }_{2} \mathrm{O}_{2}$ kernel as the reference recycle fuel in early 1974. A great deal of optimism existed at that time about the potential for this fuel and the flexibility associated with kernel processing. It was thought that kernel densities ranging from about 2.8 to $5.0 \mathrm{~g} / \mathrm{cm}^{3}$ would be possible, with compositions ranging from $\mathrm{UO}_{2}$ to $\mathrm{UC}_{2}$. The expected lower cost has already been discussed. Particle design advantages were also expected. The porosity of the kernel was thought to be sufficient to accommodate fuel swelling, thus reducing or eliminating the need for a buffer layer. 
Table 2. Summary of ORNL Experimental Data on Mixed (Th,U) Oxide Recycle Fuel Part 1. Rea1-Time Testing Under HTGR Conditions in Peach Bottom Reactor

\begin{tabular}{|c|c|c|c|c|c|c|c|c|}
\hline $\begin{array}{l}\text { Irradiation }(1,2) \\
\text { experiment } \\
\text { No. }\end{array}$ & $\begin{array}{l}\text { Batch No. } \\
\text { and } \\
\text { fuel type }\end{array}$ & $\begin{array}{l}\text { Th/v } \\
\text { rocio }\end{array}$ & $\begin{array}{l}\text { Fast fluence } \\
\mathrm{E}>0.28 \mathrm{MeV} \\
\left(\mathrm{n} / \mathrm{cm}^{2}\right)\end{array}$ & $\begin{array}{l}\text { Average } \\
\text { burnup } \\
\text { ( } \boldsymbol{X} \text { FIMA) }\end{array}$ & $\begin{array}{l}\text { Maximum } \\
\text { fuel } \\
\text { temperature } \\
\left({ }^{\circ} \mathrm{C}\right)\end{array}$ & $\begin{array}{l}\text { Des1gna } \\
(\mu \omega)\end{array}$ & $\begin{array}{l}\text { Densicy }{ }^{a} \\
\left(\mathrm{~g} / \mathrm{cm}^{3}\right)\end{array}$ & Remarks \\
\hline \multicolumn{9}{|l|}{ RTE-1 (FTE-11) } \\
\hline Body 1 & $\begin{array}{l}P R-56 \\
P R-66\end{array}$ & $\begin{array}{l}4: 1 \\
2: 1\end{array}$ & $3.3 \times 10^{21}$ & $\begin{array}{r}9.0 \\
14.7\end{array}$ & c & $\begin{array}{l}350 / 75 / 130 \\
350 / 90 / 130\end{array}$ & $\begin{array}{l}10.1 / 1.1 / 1.9 \\
10 / 1.17 / 1.86\end{array}$ & \multirow[t]{6}{*}{$\begin{array}{l}\text { Slug-1njected; carbonized in covered } \\
\text { graphite tray; to be examined. }\end{array}$} \\
\hline Body 2 & $\begin{array}{l}\mathrm{PR}-56 \\
\mathrm{PR}-66\end{array}$ & $\begin{array}{l}4: 1 \\
2: 1\end{array}$ & & $\begin{array}{r}9.0 \\
14.7\end{array}$ & & $\begin{array}{l}350 / 75 / 130 \\
350 / 90 / 230\end{array}$ & $\begin{array}{l}10.1 / 1.1 .1 .9 \\
10 / 1.17 / 1.86\end{array}$ & \\
\hline Body 3 & $\begin{array}{l}\text { PR-S6 } \\
\text { PR-67 }\end{array}$ & $\begin{array}{l}4: 1 \\
2: 1\end{array}$ & & $\begin{array}{r}9.0 \\
14.7\end{array}$ & & $\begin{array}{l}350 / 75 / 130 \\
350 / 90 / 140\end{array}$ & $\begin{array}{l}10.1 / 1.1 / 1.9 \\
10 / 1.17 / 1.85\end{array}$ & \\
\hline Body 4 & $\begin{array}{l}\mathrm{PR}-56 \\
\mathrm{PR}-67\end{array}$ & $\begin{array}{l}4: 1 \\
2: 1\end{array}$ & & $\begin{array}{r}9.0 \\
14.7\end{array}$ & & $\begin{array}{l}350 / 75 / 130 \\
350 / 90 / 140\end{array}$ & $\begin{array}{l}10.1 / 1.1 / 1.9 \\
10 / 1.17 / 1.85\end{array}$ & \\
\hline Body 5 & PR-66 & $2: 1$ & & 14.7 & & $350 / 90 / 130$ & $10 / 1.17 / 1.86$ & \\
\hline Body 6 & PR-66 & $2: 1$ & & 14.7 & 1 & $350 / 90 / 130$ & $10 / 1.17 / 1.86$ & \\
\hline \multicolumn{9}{|l|}{ RTE-2 } \\
\hline Body 2 & PR-66 & $2: 1$ & $3.6 \times 10^{21}$ & 13.3 & $1190^{\mathrm{d}}$ & $350 / 90 / 130$ & $10 / 1.17 / 1.86$ & $\begin{array}{l}\text { Slug-injected; carbonized in covered } \\
\text { graphite tray. Fuel examined from } \\
\text { highest temperature region and 1s } \\
\text { considered representative; no amoeba; } \\
\text { no 1ndication of fallure. }\end{array}$ \\
\hline Body 5 & PR-55 & $4: 1$ & $3.6 \times 10^{21}$ & 8.2 & $1300^{\mathrm{d}}$ & $350 / 70 / 80$ & $10.1 / 1.1 / 1.9$ & $\begin{array}{l}\text { Loose bed of particles; fuel examined } \\
\text { from h1ghest temperature region and } \\
\text { 1s considered representative; no } \\
\text { amoeba; no indicstion of faflure. }\end{array}$ \\
\hline \multicolumn{9}{|l|}{ RTE-4 } \\
\hline Body 3 & PR-54 & $4: 1$ & $2.0 \times 10^{21}$ & 5.0 & $1260^{d}$ & $350 / 70 / 70$ & $10.1 / 1.1 / 1.94$ & $\begin{array}{l}\text { Loose bed of particles; fuel examined } \\
\text { from h1ghest temperature region and } \\
\text { 1s considered repregentative; no } \\
\text { amoeba; no indications of fallure. }\end{array}$ \\
\hline Body 5 & PR-61 & $2: 1$ & $2.0 \times 10^{21}$ & 8.5 & $1230^{\mathrm{d}}$ & $350 / 75 / 120$ & $10.2 / 1.16 / 1.91$ & $\begin{array}{l}\text { Slug-1njected; carbonized in covered } \\
\text { graphite tray; fuel examined from } \\
\text { highest temperature reglon and is } \\
\text { considered representative; no } \\
\text { amoeba; no indication of fallure. }\end{array}$ \\
\hline \multicolumn{9}{|l|}{ RTE-S } \\
\hline Body 1 & $\begin{array}{l}\text { PR-57-1 } \\
\text { PR-61 }\end{array}$ & $\begin{array}{l}4: 1 \\
2: 1\end{array}$ & $4.6 \times 10^{21}$ & $\begin{array}{l}11.9 \\
18.4\end{array}$ & c & $\begin{array}{l}350 / 75 / 135 \\
350 / 75 / 120\end{array}$ & $\begin{array}{l}10.1 / 1.1 / 1.9 \\
10.2 / 1.16 / 1.9\end{array}$ & \multirow[t]{6}{*}{$\begin{array}{l}\text { slug-injected; carbontized in covered } \\
\text { araphite tray; to be examined. }\end{array}$} \\
\hline Body 2 & $\begin{array}{l}\mathrm{PR}-57-1 \\
\mathrm{PR}-61\end{array}$ & $\begin{array}{l}4: 1 \\
2: 1\end{array}$ & & $\begin{array}{l}11.9 \\
18.4\end{array}$ & & $\begin{array}{l}350 / 75 / 135 \\
350 / 75 / 120\end{array}$ & $\begin{array}{l}10.1 / 1.1 / 1.9 \\
10.2 / 1.16 / 1.9\end{array}$ & \\
\hline Body 3 & $\begin{array}{l}\text { PR-57-1 } \\
\text { PR-61 }\end{array}$ & $\begin{array}{l}4: 1 \\
2: 1\end{array}$ & & $\begin{array}{l}11.9 \\
18.4\end{array}$ & & $\begin{array}{l}350 / 75 / 135 \\
350 / 75 / 120\end{array}$ & $\begin{array}{l}10.1 / 1.1 / 1.9 \\
10.2 / 1.16 / 1.9\end{array}$ & \\
\hline Body 4 & $\begin{array}{l}P R-57-1 \\
P P-61\end{array}$ & $\begin{array}{l}4: 1 \\
2: 1\end{array}$ & & $\begin{array}{l}11.9 \\
18.4\end{array}$ & & $\begin{array}{l}350 / 75 / 135 \\
350 / 75 / 120\end{array}$ & $\begin{array}{l}10.1 / 1.1 / 1.9 \\
10.2 / 1.16 / 1.9\end{array}$ & \\
\hline Body 5 & $P R-60$ & $2: 1$ & & 18.4 & & $350 / 75 / 120$ & $10.2 / 1.16 / 1.9$ & \\
\hline Body 6 & PR- 60 & $2: 1$ & & 18.4 & 1 & $350 / 75 / 120$ & $10.2 / 1.16 / 1.9$ & \\
\hline \multicolumn{9}{|l|}{ RTE-6 } \\
\hline Body 3 & $P R-60$ & $2: 1$ & $4.6 \times 10^{21}$ & $18 \overline{8} .2$ & c & $350 / 75 / 120$ & $10.2 / 1.16 / 1 . y$ & $\begin{array}{l}\text { Slug-injected;carbonlzed iñ coveyed } \\
\text { graphite tray; fuel exnoined from } \\
\text { highest temperature region and is } \\
\text { considered repreaentat1ve; no amoeba; } \\
\text { no indication of fallure. }\end{array}$ \\
\hline \multicolumn{9}{|l|}{ RTE-8 } \\
\hline Body 4 & PR- 60 & $2: 1$ & $4.6 \times 10^{21}$ & 18.1 & c & $350 / 75 / 120$ & $10.2 / 1.16 / 1.9$ & $\begin{array}{l}\text { Slug-injected; carbonized in covered } \\
\text { graphite tray. }\end{array}$ \\
\hline \multicolumn{9}{|l|}{ RTE-7 } \\
\hline Body 1 & PR-60 & $2: 1$ & $1.3 \times 10^{21}$ & 5.5 & $880^{d}$ & $350 / 75 / 120$ & $10.2 / 1.16 / 1.9$ & \multirow{6}{*}{$\begin{array}{l}\text { Slug-injected; carbonized in covered } \\
\text { graphite tray; fuel examined from highegr } \\
\text { temperature rcsion and to conoldered } \\
\text { representative; no amoeba; no indications } \\
\text { of fallure. }\end{array}$} \\
\hline Body 3 & $D_{R}=60$ & $2 \cdot 1$ & & 5.5 & $1130^{\mathrm{d}}$ & $350 / 75 / 120$ & $10.2 / 1.16 / 1.9$ & \\
\hline Body 3 & PR-60 & $2: 1$ & & 5.5 & $1230^{\mathrm{d}}$ & $350 / 75 / 120$ & $10.2 / 1.16 / 1.9$ & \\
\hline Body 4 & $P R-60$ & $2: 1$ & & 5.5 & $1230^{\mathrm{d}}$ & $350 / 75 / 120$ & $10.2 / 1.16 / 1.9$ & \\
\hline Budy' & $\begin{array}{l}\text { PR- } 57-1 \\
P R-57-6 \\
P R-61\end{array}$ & $\begin{array}{l}4: 1 \\
4: 1 \\
2: 1\end{array}$ & . & $\begin{array}{l}3.7 \\
3.2 \\
5.5\end{array}$ & $\begin{array}{l}115 n^{\mathrm{d}} \\
1150^{\mathrm{d}} \\
1150^{\mathrm{d}}\end{array}$ & $\begin{array}{l}350 / 7.5 / 1.35 \\
350 / 75 / 135 \\
350 / 75 / 120\end{array}$ & $\begin{array}{l}10.1 / 1.1 / 1.9 \\
10.1 / 1.1 / 1.9 \\
10.2 / 1.16 / 1.9\end{array}$ & \\
\hline Body 6 & $\begin{array}{l}\mathrm{PR}-57-1 \\
\mathrm{PR}-61\end{array}$ & $\begin{array}{l}4: 1 \\
2: 1\end{array}$ & & $\begin{array}{l}3.2 \\
5.5\end{array}$ & $\begin{array}{l}1050^{d} \\
1050^{d}\end{array}$ & $\begin{array}{l}350 / 75 / 135 \\
350 / 75 / 120\end{array}$ & $\begin{array}{l}10.1 / 1.1 / 1.9 \\
10.2 / 1.16 / 1.9\end{array}$ & \\
\hline
\end{tabular}


Table 2 - Part 2. Accelerated Testing in Research Reactors

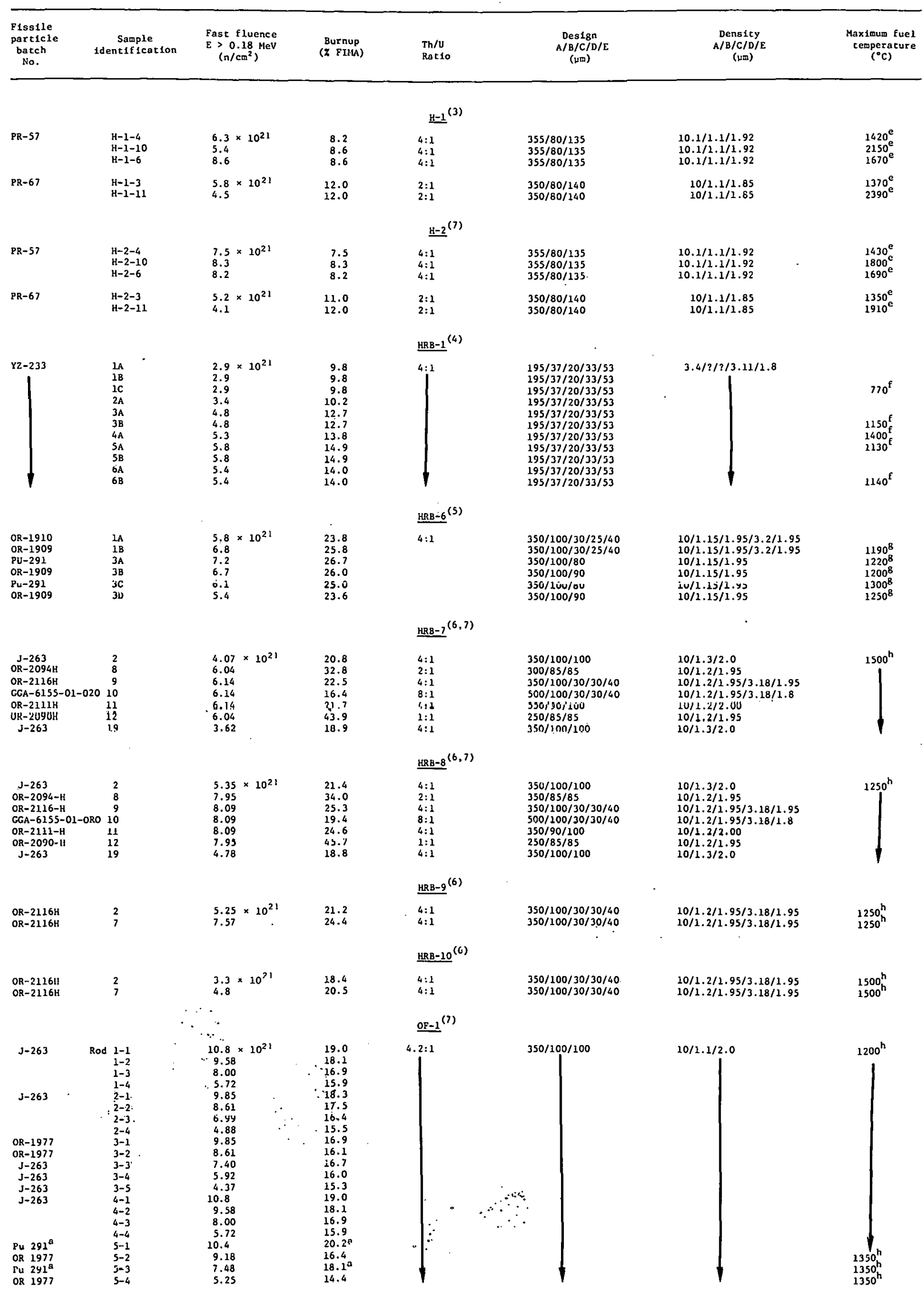


Table 2 - Part 2a.

\begin{tabular}{lll}
\hline $\begin{array}{c}\text { Fissile } \\
\text { particle } \\
\text { batch } \\
\text { No. }\end{array}$ & $\begin{array}{c}\text { Sample } \\
\text { 1dentification }\end{array}$ & Renarks \\
\hline
\end{tabular}

\section{$\underline{H-1}$}

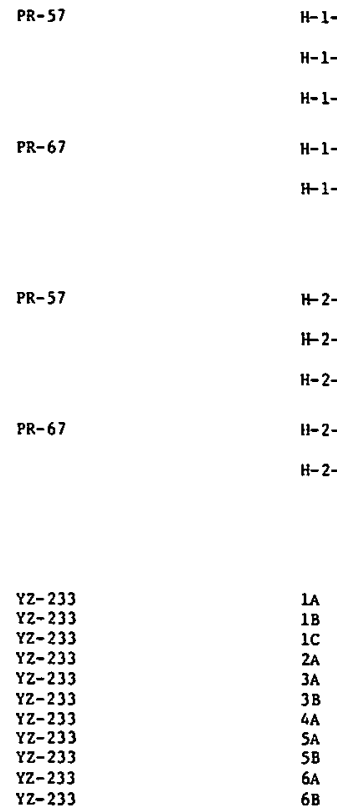

Only fallures noted in single plane of polish viewed were due to fabrication defects. very high temperatures during fourth cycle; extensive damage at center of rod.

Loose particles. Amoeba related failures.

Only slight evidence of amoeba; no falled coatings.

Rod debonded Into large fragments; damaged particles on surface of rod.

$\underline{\mathrm{H}-2}$

Not examined; sent to Chemical Technology Division for reprocessing studies. Center badly damaged due to very high temperature during last cycle.

Loose particles. Not examined.

Fuel rod debonded; no falled particles observed during visual examination.

Cuter surfaces of particles near the surface of rod chemically attacked; amoeba apparent; kernel migrated through buffer and into LTI.

$\underline{\text { HRB-1 }}$

Slug-infected rods; thin two-component sacrifictal layer on outer surface of particles caused debonding of rods with low-density matr1x (1A, 2B, 1C, 2A, 4A, 4B). Metallography showed no falled particles or amoeba.

$\underline{\text { FRB-6 }}$

OR-1910

OR-1909 1 B

Pu-291* $3 A$

OR-1909 3B

$P u-291^{*} \quad 3 C$

OR-1909 3D

$\mathrm{J}-263$

UK-2U்'4H

OR-2116H

CCN-615S-01-020 10

OR-2111H 11

OR-2090H

J-26: 19

$\begin{array}{lr}\mathrm{J}-263 & 2 \\ \text { OR-2094-H } & 8 \\ \text { OR-2116-H } & 9 \\ \text { GCA-615S-01-020 } & 10 \\ \text { OR-2111-H } & 11 \\ \text { OR-2090-H } & 12 \\ J-263 & 19\end{array}$

Extruded rod: no fallures: no amoobs: Intermitcont plastic flow through recoll zono. Excruded rod; no fallures; slight amoebs $(2-3 \mathrm{um})$; Intermittent plastic flow through recoll zone. Slug-injected; carbonized in packed $\mathrm{Al}_{2} \mathrm{O}_{3}$; > $50 \mathrm{z}$ falled; amoebs $(20 \mathrm{\mu m})$; fallures attributed to def ective coarings.

Slug-injecced; carbonized in packed $\mathrm{Al}_{2} \mathrm{O}_{3}$; no fallures; amoeba $(20 \mathrm{um})$.

Slug-1nfected; carbonized in packed $\mathrm{Al}_{2} \mathrm{O}_{3}$; visual examination only; no broken particles. Slug-injected; carbonized in packed $\mathrm{Al}_{2} \mathrm{O}_{3}$; visual exanination only; no broken particlee.

\section{$\underline{10 R D}=7$}

Slug-infected; carbonlzed in packed $\mathrm{Al}_{2} \mathrm{O}_{3} ;$ no fallures; amoeba ( $\leq 40 \mathrm{um}$ ). Slug-Injected; carbonlzed In packed $\mathrm{Al}_{2} \mathrm{O}_{3}$; no fallures; amoeba ( $\underline{80} \mathrm{um}$ ) Slug-infected; carbonlzed in packed $\mathrm{Al}_{2} \mathrm{O}_{3}$; no fallures; amoeba ( $\left.\leq 25 \mathrm{um}\right)$

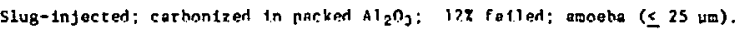
Slug-infected; carbonized in packed $\mathrm{Al}_{2} \mathrm{O}_{3}$; no fallures; ampeba $(\leq 75 \mathrm{um})$ slug-infected; carbonized 1n packed $\mathrm{Al}_{2} \mathrm{O}_{3} ;$ no fallures; amoeba ( $\leq 55 \mathrm{um}$ ). Slug-infected; carbonized in packed $A 1, O_{3} ;$ no fallures; anoeba ( $\left.\leq 30 \mathrm{um}\right)$.

\section{HRB-8}

Slug-injected; carbonlzed in packed $\mathrm{Al}_{2} \mathrm{O}_{3}$; no tallures; amoeba (L $13 \mathrm{um}$ ). Slug-injected; carbonized in packed $\mathrm{Al}_{2} \mathrm{O}_{3} ;$ no fallures; amoeba ( $\leq 20 \mathrm{um}$ ). Slug-injected; carbonized in packed $\mathrm{Al}_{2} \mathrm{O}_{3} ;$ no fallures; amoeba (S 25 uD). slug-injected; carbonized in packed $\mathrm{Al}_{2} \mathrm{O}_{3} ;$ no fallures; amoeba ( $\leq 85 \mu \mathrm{m}$ ). slug-injected; carbonized in packed $\mathrm{Al}_{2} \mathrm{O}_{3}$; no fallures; amoeba ( $20 \mathrm{um}$ ). slug-injected; carbonized in packed $\mathrm{Al}_{2} \mathrm{O}_{3} ; 132$ falled; amoeba ( $\leq 55 \mathrm{um}$ ). slug-injected; carbonized in packed $\mathrm{Al}_{2} \mathrm{O}_{3}$ : no fallures; amoeba (s $20 \mathrm{um}$ ). 
Table 2 - Part 2a. (Continued)

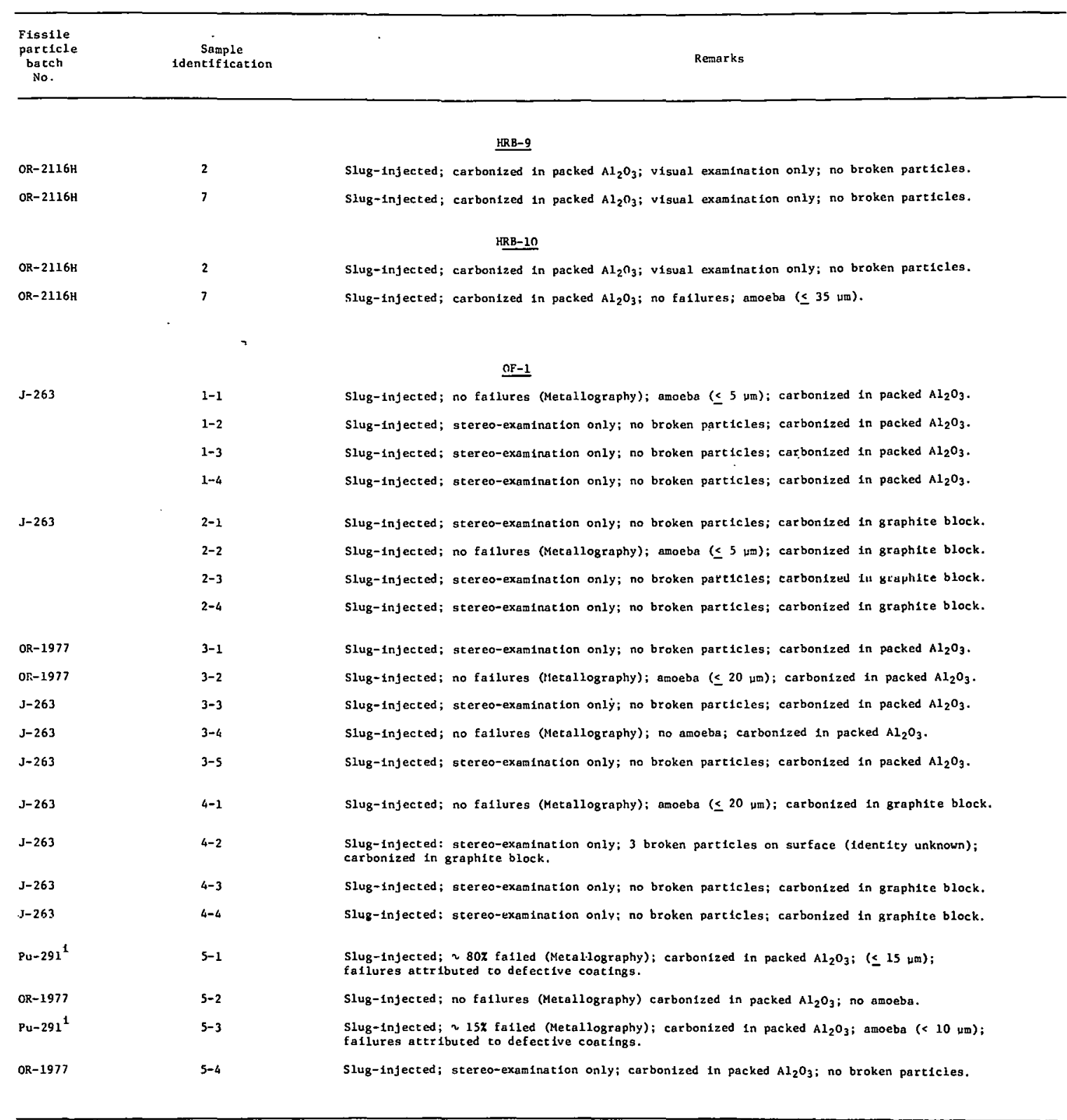

$a_{A}$ - kernel; B - buffer; $C=I P y C ; D=S i C ; E=$ OPyC.

Approximately 11,000 to 18,000 E1ssile particles per rod In RTE fuel rods, depanding on particle diameter and density. Forty-eight fuel rods per body.

cThermal analysis to be completed by July 1976.

Araximum fuel temperature in fuel body. These are estimated temperacures based on as-fabricated dimensions. Detalled analyses incorporating irradiation-induced dimensional changes are being performed.

These temperatures represent the maximum calculated for the fuel rod centerilne during the 1rradiation. This experiment was complicated by a nonintentional inversion of the capsule during the last of four irradiation cycles. (See ref. 4 for additional details on fuel operating temperatures.)

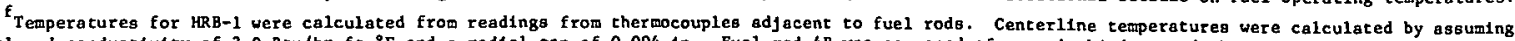
a fuel rod conductivity of $3.0 \mathrm{Btu} / \mathrm{hr}-\mathrm{f} t-^{\circ} \mathrm{F}$ and a rad1al gap of $0.004 \mathrm{in}$. Fuel rod $4 \mathrm{~B}$ was composed of a resin b1nder, and the matr1x debonded rather badly during 1rradiation. Therefore, the thermal conductivity of the fuel rod may have been as low as $1.5 \mathrm{Btu} / \mathrm{hr}-\mathrm{ft} \mathrm{-}^{\circ} \mathrm{F}$ (a value absociated with loose beds

particle). Th1s change in the bed conductivit
B From detailed thermal analysis (ref. 5).

Maximum design fuel temperacures.

$1_{\text {Fueled with }}{ }^{23} \mathrm{u}$.

References $\mathrm{l}_{\mathrm{E}}$. L. Long, Jr, et al., Fabrication of ORNL Fual Irradiated in the Peach Bottom Reactor and Postirradiation Escarination of Recycle Tost
Elements 7 and 4, ORNL-MM-4477 (September 1974).

2R. P. Mor1ssette and K. P. Steward, Recycle Test Element Program Design, Fahrication, and Assenbly, GA-10109 (September 1971).

${ }^{3}$ R. A. Olstad et al., An Irradiation Test of Candidate HTGR Recycle Fuels in the H${ }^{1}$ and H-2 Capsules, ORNL-TM-4397 (July 1974).

4.J. L. Scott et al., An Irradiation Test of Bonded HTGR Coated Particle Fuele in an Instrumented Capoule in HFIR, ORNL-TM-3640 (March 1972).

$5_{\mathrm{F}}$. J. Homen et a1.. Irradiation Performance of HTGR Fuel Rodi in HPIR Experiment HRB-6, ORNL-TM-5011 (December 1975).

${ }_{\mathrm{K}}$. H. Valentinc et al., Irradiation Ferformance of HTGR Fuil Rods in HFIR Experiments in HRB-7 and -8 , in preparation.

7HTGR Base Program Progr. Rep. Jan. 1, 1974 to June 30, 1975, ORNL-5108, In preparation. 

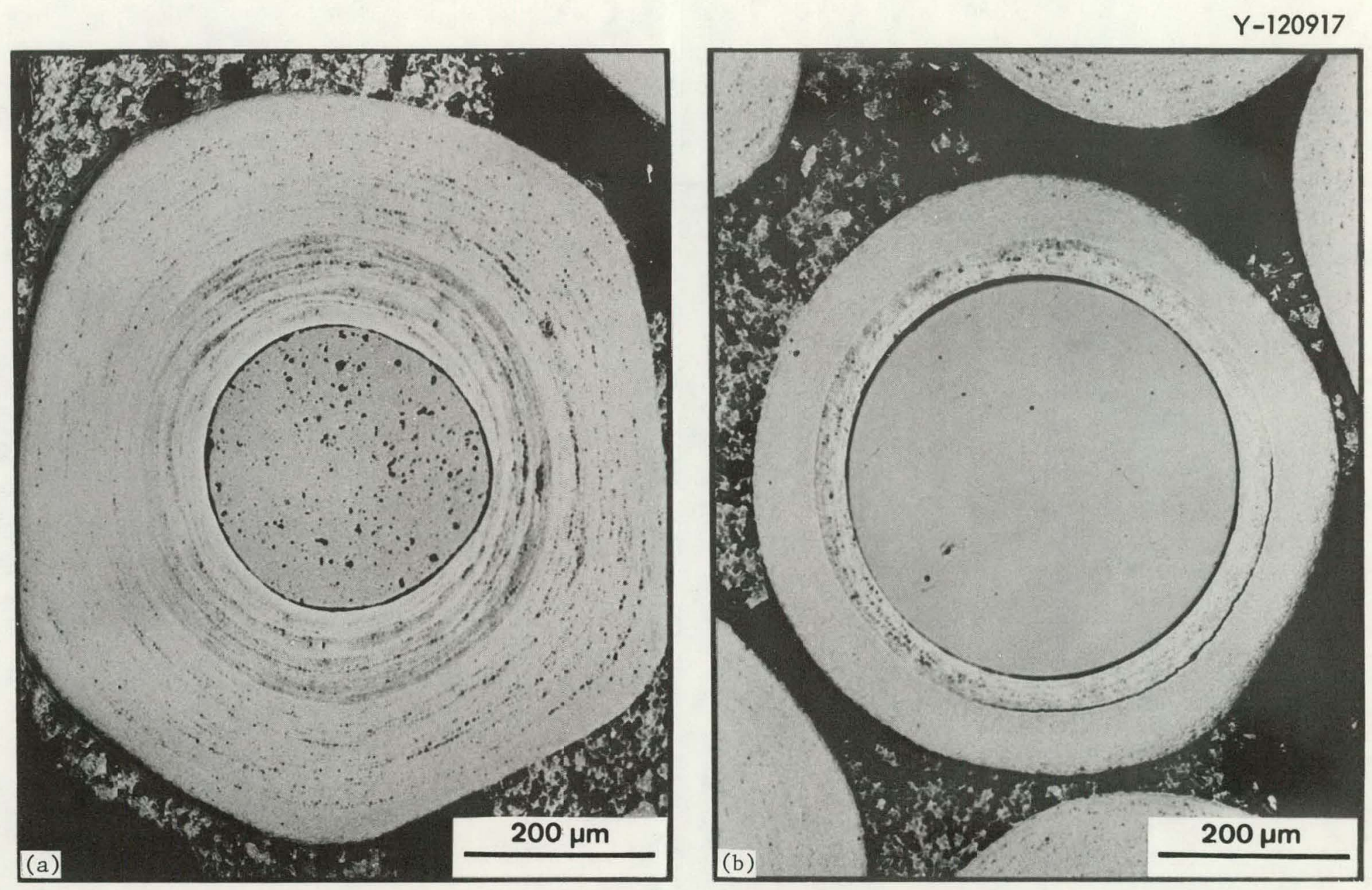

Fig. 4. Relative Thermal Stability of Fissile and Fertile Particles in Irradiation Test $\mathrm{H}-1-4$. Temperature, $1050^{\circ} \mathrm{C}$; thermal gradient, $1200^{\circ} \mathrm{C} / \mathrm{cm}$; fast fluence, $6.3 \times 10^{21} \mathrm{n} / \mathrm{cm}^{2}$; time at power, 134 days.
(a) $(4.1 \mathrm{Th}, \mathrm{U}) \mathrm{O}_{2}$ (8.2\% FIMA).
(b) $\mathrm{ThO}_{2}$ (0.4\% FIMA). 
$Y-120709$

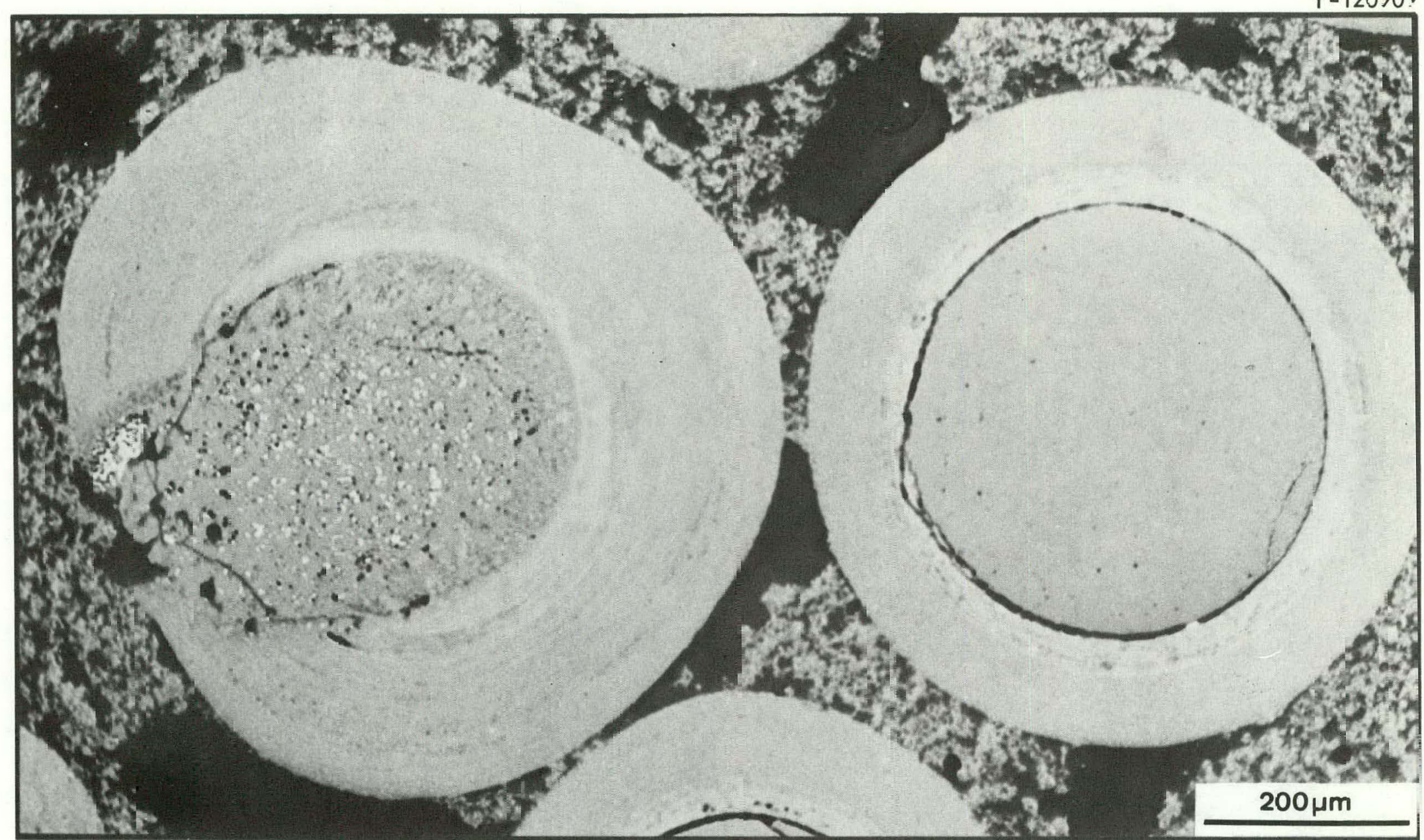

Fij. 5. Relative Thermal Stability $c \equiv$ Fissile and Fertile Kernels in Irradiation Test E-2-10. Temperature: $1350^{\circ} \mathrm{C}$; thermal gradient, $17 \mathrm{C0} 0^{\circ} \mathrm{C} / \mathrm{cm}$; fast fluence, $5 \times 10^{21} \mathrm{n} / \mathrm{cm}^{2}$; time at full power, 37 days. Left: (4Th, U) $\mathrm{O}_{2}\left(8.3 \%\right.$ FIMA). Right: Th' ${ }_{2}(0.3 \% \exists T M A)$. 
TEMPERATURE $\left({ }^{\circ} \mathrm{C}\right)$

ORNL-DWG 74-3925R

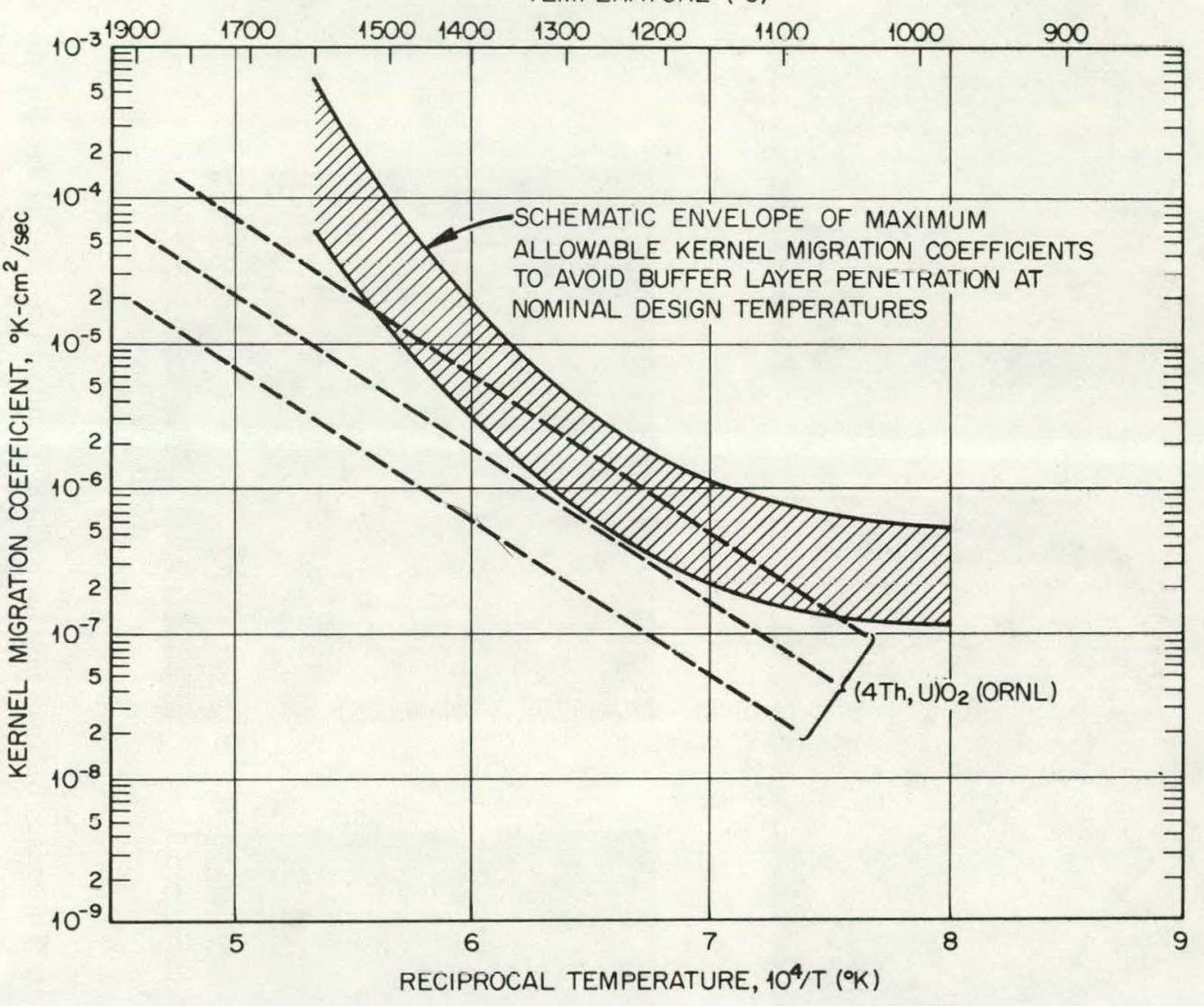

Fig. 6. Average Kernel Migration Coefficients for $(4 \mathrm{Th}, \mathrm{U}) \mathrm{O}_{2}$. 


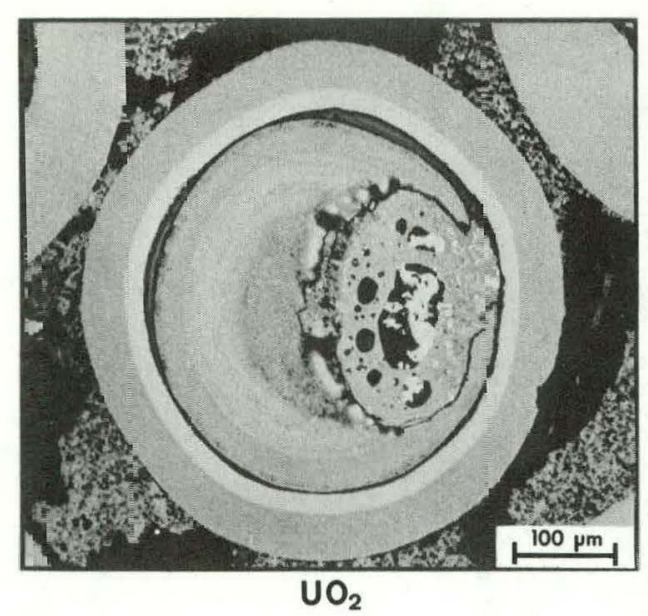

R-65778

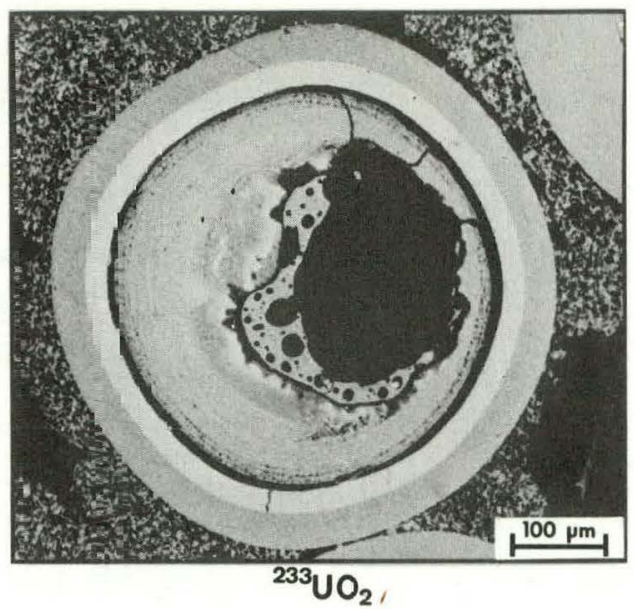

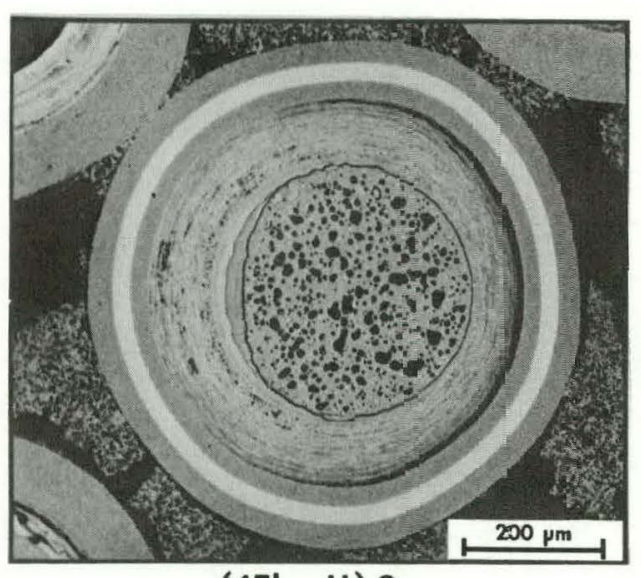

$(4 \mathrm{Th}, \mathrm{U}) \mathrm{O}_{2}$

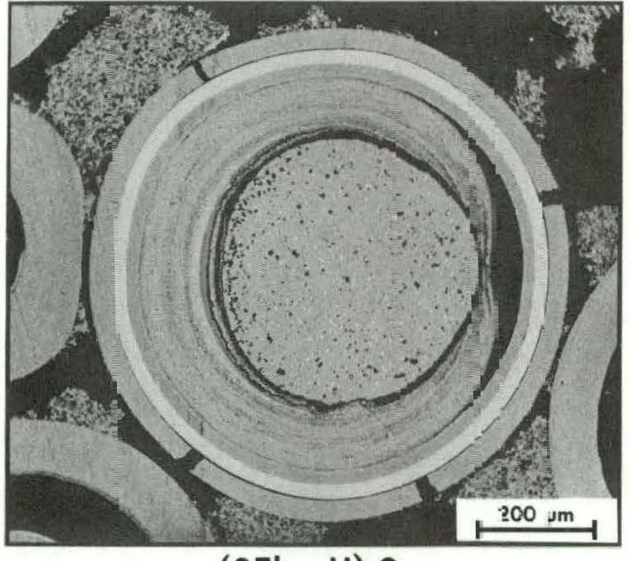

$(8 \mathrm{Th}, \mathrm{U}) \mathrm{O}_{2}$

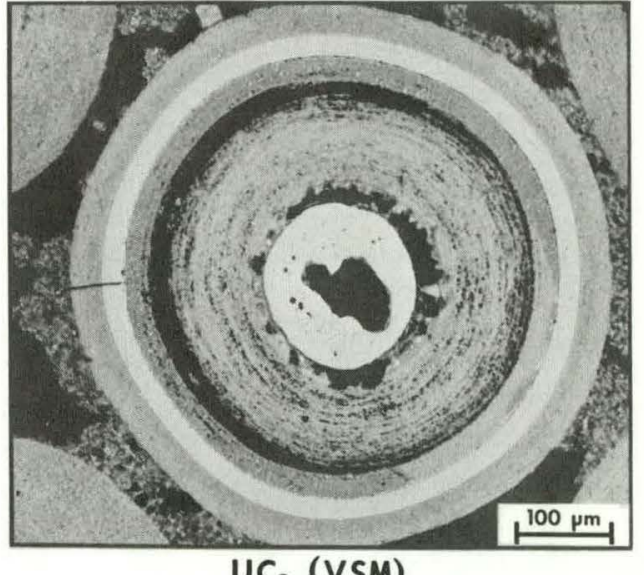

$\mathrm{UC}_{2}$ (VSM)

Fig. 7. Relative Thermal Stability of HTGR Candilate Recycle Oxide vs Reference UC Fissile $^{2}$ Fis Particles. $\quad 4-6 \times 10^{21} \mathrm{n} / \mathrm{cm}^{2}(>0.18 \mathrm{MeV}) ; 80 \%$ FIMA; $1530{ }^{\circ} \mathrm{C}$ design centerline temperature. 
It should be emphasized that while only limited irradiation data existed on WAR fuel in early 1974 a considerable amount of data existed on resin-based fuel systems. This data included evaluation of several ion-exchange resins; various uranium-loading schemes; effects of varying carbonization cycles; control of conversion or reduction to carbide; and atmospheric requirements for handling, coating, and irradiation testing. ${ }^{9-14}$ Recent development effort has been concentrated on WAR fuel employing acrylic acid-divinylbenzene copolymers, Amberlite IRC-72, manufactured by Rohm and Haas, and Duolite C-464, manufactured by Diamond Shamrock. Resin particles in $\mathrm{Na}^{+}$form are obtained without upgrading for size or shape. The bulk of the particles are spherical, but are distributed over a broad range of sizes. The material is wetscreened to obtain the size fraction required, about 600 to $800 \mu \mathrm{m}$ in the wet $\mathrm{Na}^{+}$form, dried, and shape separated on vibrating trays to remove the nonspherical fraction. Yield of sized spheres is about $20 \%$ of as-received resin. This ability to thoroughly upgrade unfueled particles by a contact process before loading the uranium is a major advantage of the resin process for fuel recycle since all operations involving recycle fuel must be done remotely. The sized microspheres are then remoistened and converted to $\mathrm{H}^{+}$form for loading of uranium.

Of the many possible schemes for loading uranium, all studied extensively at ORNL employ $\mathrm{H}^{+}$form resin and thus require acid-deficient loading liquors. The currently favored process uses uranyl nitrate. with acid deficiency maintained by amine extraction. ${ }^{3}$ Reaction equilibrium is maintained to favor the replacement of $\mathrm{H}^{+}$pairs by $\mathrm{UO}_{2}^{2+}$ ions to achieve essentially $100 \%$ loading of resin capacity. After the resin is fully loaded it is washed and dried at $110^{\circ} \mathrm{C}$.

Fabrication of fuel kernels from dried resin involves carbonization of the resin structure followed by conversion or reduction to adjust the oxygen content. Product properties are sensitive to control in both steps. Both carbonization and conversion are carried out in an argon-fluidized bed, which allows the necessary control of temperature, heating rate, and atmosphere. Varying the carbonization cycle, specifically the rate of heating between 350 and $450^{\circ} \mathrm{C}$, has a critical effect on density and carbon content of the final product. Critical carbonization reactions of the resin are nearly complete at $450^{\circ} \mathrm{C}$, and the residual carbon yield increases strongly with decreasing rate of heating to that point; heating rate above $450^{\circ} \mathrm{C}$ is relatively unimportant. Weight loss, volume shrinkage, and the carbon-to-uranium ratio $(\mathrm{C} / \mathrm{U})$ of the carbonized product vary with heating rate through the critical range between 350 and $450^{\circ} \mathrm{S}$ for the Amberlite resin (Fig 8). Thus, considerable flexibility is available to tailor properties of the product since uranium-lnaded WAR can be heated through the critical range at rates as high as $300^{\circ} \mathrm{C} / \mathrm{min}$ without destroying microsphere integrity. The carbonized material, after heating to $1200^{\circ} \mathrm{C}$, can have densities ranging from about 2.8 to $3.8 \mathrm{~g} / \mathrm{cm}^{3}$ and $\mathrm{C} / \mathrm{U}$ ranging from about 4 to 6 , depending on carbonization rate. Slow carbonization results in more porosity as well as more retained carbon to give lower 

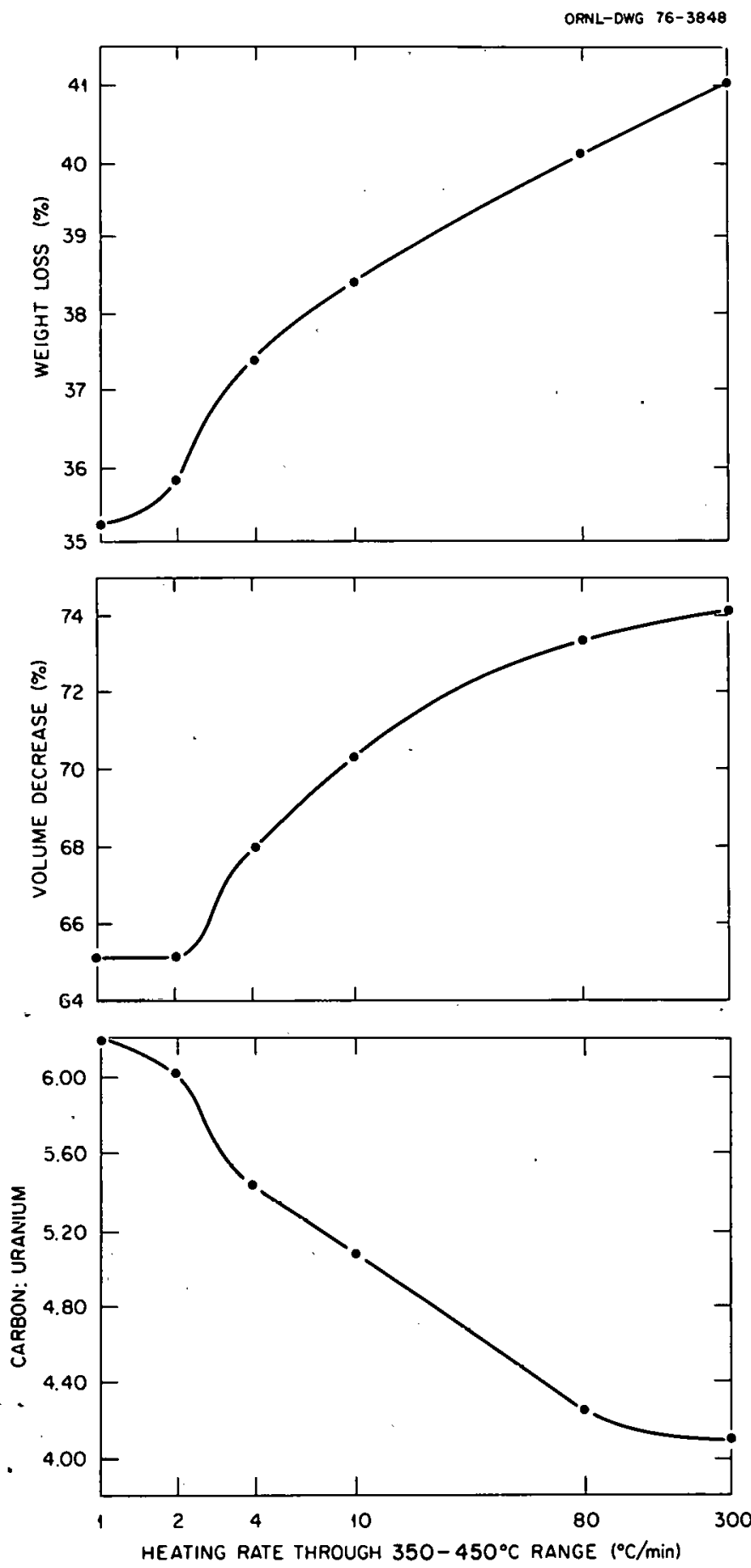

Fig. 8. Effect of Critical Range $\left(350-450^{\circ} \mathrm{C}\right)$ Heating Rate on Carbonization of Uranium-Loaded Weak-Acid Resin (Amberlite IRC-72.) Carbonized to $1200^{\circ} \mathrm{C}$. 
density. After carbonization, the material formula may be written as $\mathrm{UO}_{2}+n \mathrm{C}$, where $n$ varies from 4 to 6 . The fuel phase is poorly crystalline $\mathrm{UO}_{2}$ finely dispersed in a porous glassy carbon matrix. The kernels may be coated at this point if oxide fuel is desired.

If carbide or mixed oxide-carbide fuel is desired, conversion is effected by heating in the argon-fluidized bed. Residual carbon from the resin is sufficient for complete carbothermic reduction, and again the process is very flexible in allowing control of product properties. The fluidized bed offers excellent control of reduction rate as long as the microspheres are well fluidized and do not sinter appreciably. Since the carbonized material has an extensive system of interconnected porosity, reduction rate is limited, not by solid-state diffusion, but by rate of carbon monoxide removal. The carbon monoxide partial pressure in the bed is fixed at approximately the equilibrium $P_{C O}$ for the reaction:

$$
\mathrm{UO}_{2}+4 \mathrm{C} \rightarrow \mathrm{UC}_{2}+2 \mathrm{CO},
$$

or

$$
\mathrm{UO}_{2}+3 \mathrm{C} \rightarrow \mathrm{UC}+2 \mathrm{CO} \text {. }
$$

The difference in equilibrium $P_{C O}$ for the above reactions is not significant relative to experimental error in temperature control. The reaction rate can be calculated from

$$
f_{\mathrm{CO}}=P_{\mathrm{Co}} f_{\mathrm{Ar}} /\left(P_{\text {total }}-P_{\mathrm{CO}}\right)
$$

where

$$
\begin{aligned}
f_{\mathrm{CO}} & =\text { evolving carbon monoxide flow rate, } \\
f_{\mathrm{Ar}} & =\text { flow rate of argon, } \\
P_{\text {total }} & =\text { atmospheric pressure, and } \\
P_{\mathrm{CO}} & =\text { equilibrium } P_{\mathrm{CO}} \text { for temperature employed. }
\end{aligned}
$$

For the $1500-1600^{\circ} \mathrm{C}$ range commonly used, where $P_{C O}$ is less than $4 \%$ of atmospheric pressure, the reaction rate can be adequately predicted from

$$
f_{\mathrm{CO}}=P_{\mathrm{COF}}{ }^{\mathrm{Ar}} / P_{\text {total }}
$$

Thus, reduction rate is predictably controlled by temperature and specific argon flow rate (Fig. 9) as long as interconnected porosity is retained. 15 Whether microspheres densify and lose this porosity depends sensitively on the C/U (i.e., early carbonization rate). If the C/U after carbonization is near 6 , the material does not densify on conversion to carbide, 


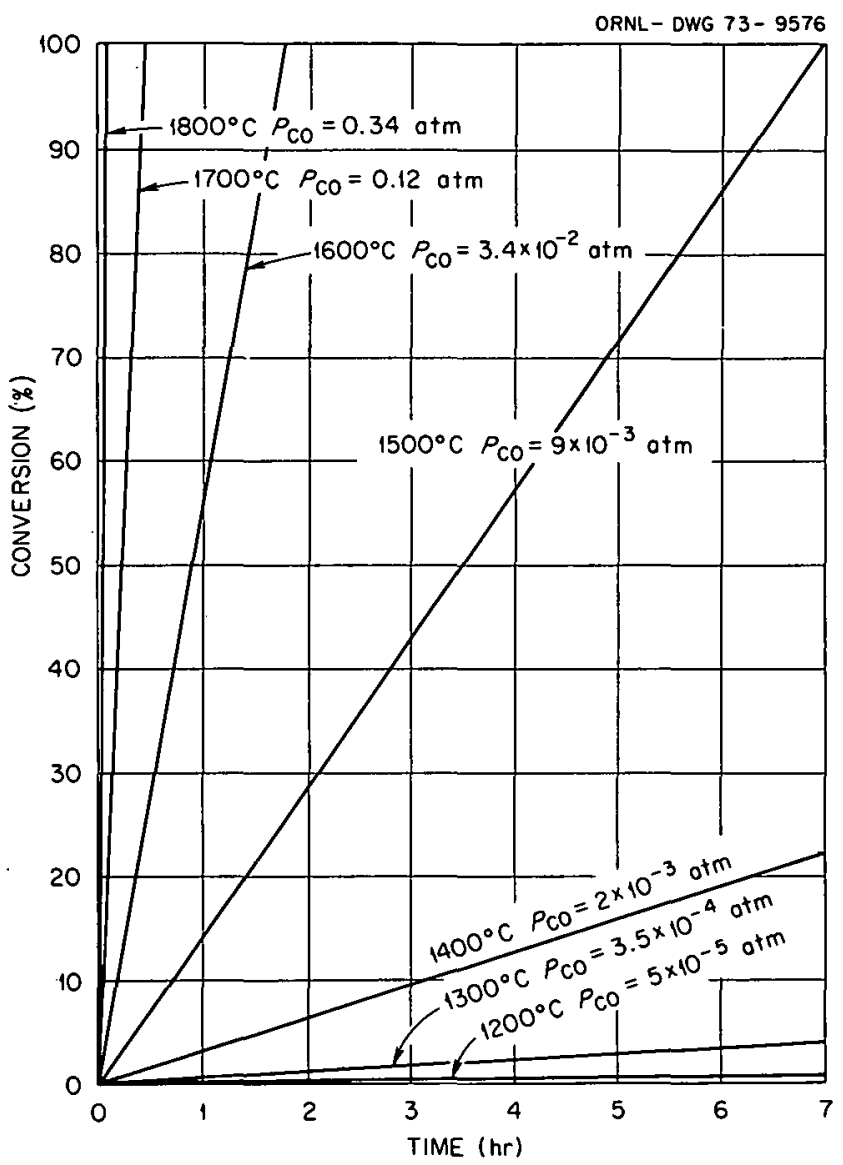

Fig. 9. Fluidized-Bed Conversion of Uranium-Loaded Weak-Acid Resin from Oxide to Carbide. (Assumed equilibrium $P_{\mathrm{CO}}$ for reaction $\mathrm{UO}_{2}+3 \mathrm{C} \rightarrow$ $\mathrm{UC}+2 \mathrm{CO}$. Normalized to $0.05 \mathrm{liter} / \mathrm{min}$ of owcep gas per g uf U.)

and the reduction rate is essentially linear with time to completion. On the other hand, if $\mathrm{C} / \mathrm{U}$ after carbonization is less than about 5.6, the microspheres begin to sinter after partial reduction so reduction rate is not readily predictable. Sintering, of course, does not preclude complete reduction, and dicarbide particles of density greater than $6.0 \mathrm{~g} / \mathrm{cm}^{3}$ can be produced this way. However, if a low-density $\left(-3.0 \mathrm{~g} / \mathrm{cm}^{3}\right)$ dicarbide or a controlled oxide-carbide composition is the desired product, the process must be suitably regulated throughout. To avoid particle densification at high temperatures, a heating rate of $2{ }^{\circ} \mathrm{C} / \mathrm{min}$ or slower is necessary through the $350-450^{\circ} \mathrm{C}$ range. Given this restriction the WAR process is ideally suited to production of any oxide-carbide composition. The significance of this process capability will be discussed later. At this stage the kernel consists of $\mathrm{UO}_{2}, \mathrm{UC}_{2}$, and free carbon and the material formula may be written as $\mathrm{UC}_{x} \mathrm{O}_{y}$, where $y$ varies from 0 to 2 and $x$ from about 2.5 to 6 . Major fuel phases present in partially converted $\mathrm{WAR}$ fuel are $\mathrm{UO}_{2}$ and $\mathrm{UC}_{2}$. A nonequilibrium minor phase, $\mathrm{UC}_{x} \mathrm{O}_{1-x}$, may be present in partially converted fuel, depending on the conversion process control exercised, but this phase will decompose to $\mathrm{UO}_{2}$ and $\mathrm{UC}_{2}$ in subsequent processing or in the reactor. 
IRRADIATION PERFORMANCE OF WAR FISSILE FUELS

The decision to switch from $\mathrm{Th}_{0.8} \mathrm{U}_{0 .} \mathrm{O}_{2}$ to WAR $\mathrm{UC}_{x} \mathrm{O}_{y}$ as the reference recycle fissile kernel was based on the performance of WAR fuel in the HRB-4 and -5 capsules (Table 3 ). ${ }^{16}$ Typical postirradiation metallography of the WAR fuel irradiated in those capsules is shown in Figs. 10 and 11. Extensive testing of WAR-derived fuels was conducted in HFIR capsules HRB-7 and -8 (ref. 17) and capsules HRB-9 and -10 (ref. 18). In these capsules direct comparisons were made between the performance of WAR fuels of various compositions, and dense mixed-oxide fuels, as well as with the reference HTGR fresh fuel (dense $\mathrm{UC}_{2}$ ).

Conclusions about WAR fuel performance from this accelerated testing are summarized:

1. The porous WAR kernels densify considerably under irradiation (Fig. 10). The density of the WAR kernels is typically about $3 \mathrm{~g} / \mathrm{cm}^{3}$ before irradiation, compared with densities greater than $10 \mathrm{~g} / \mathrm{cm}^{3}$ for the dense mixed-oxide kernels described earlier. Frequently the densified WAR kernels remain attached to one side of the coating layers (Fig. 10). There is no correlation between temperature gradient and the orientation of the densified kernel.

2. There is no evidence of amoeba with WAR kernels containing more than $15 \%$ carbide, with the remainder as oxide. However, WAR $\mathrm{UO}_{2}$ kernels have been observed (Fig. 12) to migrate up the temperature gradient, just as the dense oxide kernels described earlier. As indicated earlier, WAR kernels containing a carbide phase of more than $15 \% \mathrm{UC}_{2}$, tend to be attached to the coating layers on one side of the particle, but there is no correlation with temperature gradient, so this cannot be classified as amoeba. There may be some temptation by the reader to compare the appearance of the WAR particles (Figs. 10 and 11) with the $\mathrm{UO}_{2}$ kernel (Fig. 1); however, it is emphasized that the operating temperature for the $\mathrm{UO}_{2}$ kernel was only about $950^{\circ} \mathrm{C}$ compared to temperatures of about $1350^{\circ} \mathrm{C}$ for the WAR kernels. At these modest temperatures $\mathrm{UO}_{2}$ performs well, but neither $\mathrm{UO}_{2}$ or mixed oxide perform well in the $1350^{\circ} \mathrm{C}$ range (Fig. 5).

3. Some phase segregation is associated with WAR kernels containing $85 \%$ oxide ( $15 \%$ carbide) under irradiation (Figs. 13 and 14 ). So far this phase segregation has been observed only in the WAR $85 \%$ $\mathrm{UO}_{2}$ fuel.

4. There is considerable fission product attack on the silicon carblde cualings by fission products $L a, C e, P r$, and Nd in WAR U. 2 fuels. This same type of attack has been observed in dense $\mathrm{UC}_{2}$ fuels, irradiated in $\mathrm{HRB}$ capsules under accelerated conditions, and a1so in the Peach Bottom Reactor under real-time conditions. The presence of $\mathrm{UO}_{2}$ reduces the fission product attack of the silicon carbide layer, apparently by the formation of stable rare earth oxides, which are 
Table 3. Summary of ORNL Experimental Data on Irradiated Weak-Acid-Resin-Derived Recycle Fuel

\begin{tabular}{|c|c|c|c|c|c|c|c|c|c|}
\hline $\begin{array}{l}\text { Fissile } \\
\text { particle } \\
\text { batch } \\
\text { No. }\end{array}$ & $\begin{array}{l}\text { Number of } \\
\text { particles } \\
\text { Irradiated }\end{array}$ & $\begin{array}{c}\text { Sample } \\
\text { Identffication }\end{array}$ & $\begin{array}{l}\text { Fasc fluence } \\
\mathrm{E}>0.18 \mathrm{MeV} \\
\left(\mathrm{n} / \mathrm{cm}^{2}\right)\end{array}$ & $\underset{\text { (Z Furnup }}{\text { BuA) }}$ & Resin & $\begin{array}{l}\text { Conversion } \\
\quad(x)\end{array}$ & $\begin{array}{c}\text { Des180 } \\
\mathrm{A} / \mathrm{B} / \mathrm{C} / \mathrm{D} / \mathrm{F} \\
(\mu \mathrm{m})\end{array}$ & $\begin{array}{l}\text { Density }{ }^{b} \\
A / B / C / D / E \\
\left(g / \mathrm{cm}^{3}\right)\end{array}$ & $\begin{array}{c}\text { Maximum fuel }{ }^{\mathrm{C}} \\
\text { temperature } \\
\left({ }^{\circ} \mathrm{C}\right)\end{array}$ \\
\hline \multicolumn{10}{|c|}{$\underline{\mathrm{HRB}-5}^{(1)}$} \\
\hline $52 \mathrm{~A}$ & $\begin{array}{l}5750 \\
5840 \\
5900 \\
2950 \\
2950 \\
2950 \\
2950\end{array}$ & $\begin{array}{l}1 \mathrm{~A} \\
1 \mathrm{~B} \\
1 \mathrm{C} \\
3 \mathrm{~A} \\
3 \mathrm{~B} \\
3 \mathrm{C} \\
3 \mathrm{D}\end{array}$ & $\begin{array}{l}3.4 \times 10^{21} \\
4.0 \\
4.5 \\
4.2 \\
3.9 \\
3.6 \\
3.2\end{array}$ & $\begin{array}{l}13 \\
14 \\
16 \\
15 \\
14 \\
13 \\
12\end{array}$ & IRC-72 & 95 & $350 / 40 / 30 / 30 / 30$ & $6 / 1.1 / 1.9 / 3.18 / 1.85$ & 1250 \\
\hline \multicolumn{10}{|c|}{$\underline{\mathrm{HRB}-4}^{(1)}$} \\
\hline $52 \mathrm{~A}$ & $\begin{array}{l}5750 \\
5840 \\
5900 \\
2950 \\
2950 \\
2950 \\
2950\end{array}$ & $\begin{array}{l}1 \mathrm{~A} \\
1 \mathrm{~B} \\
1 \mathrm{C} \\
3 \mathrm{~A} \\
3 \mathrm{~B} \\
3 \mathrm{C} \\
3 \mathrm{D}\end{array}$ & $\begin{array}{r}7.8 \\
9.2 \\
10.3 \\
9.6 \\
8.9 \\
8.1 \\
7.2\end{array}$ & $\begin{array}{l}24 \\
27 \\
29 \\
27 \\
25 \\
23 \\
20\end{array}$ & $\mathrm{IRC}-72$ & 95 & $350 / 40 / 30 / 30 / 30$ & $\left.\right|^{6 / 1.1 / 1.9 / 3.18 / 1.85}$ & 1250 \\
\hline \multicolumn{10}{|c|}{$\underline{\text { HRB }-6}^{(2)}$} \\
\hline $\begin{array}{l}\text { Pu-295B } \\
\text { Pu-296 } \\
\text { Pu-297 }\end{array}$ & $\begin{array}{l}28 \\
25 \\
22\end{array}$ & $\begin{array}{l}1 \mathrm{C} 4 \\
1 \mathrm{C} 5 \\
1 \mathrm{C} 6\end{array}$ & $\begin{array}{l}7.7 \\
7.7 \\
7.7\end{array}$ & $\begin{array}{l}84 \\
84 \\
84\end{array}$ & $\begin{array}{l}\text { IRC-72 } \\
\text { IRC-72 } \\
\text { IRC-72 }\end{array}$ & $\begin{array}{l}? \\
95 \\
95\end{array}$ & $\begin{array}{l}400 / 35 / 25 / 30 / 25 \\
400 / 35 / 25 / 30 / 25 \\
400 / 35 / 25 / 30 / 25\end{array}$ & $\begin{array}{l}3.2 / 1.2 / 1.95 / 3.18 / 1.95 \\
3.8 / 1.2 / 1.95 / 3.18 / 1.95 \\
3.7 / 1.2 / 1.95 / 3.18 / 1.95\end{array}$ & $\stackrel{1250}{\dagger}$ \\
\hline \multicolumn{10}{|c|}{$\underline{H R B-7}^{(3)}$} \\
\hline $\begin{array}{l}\text { OR-2115H } \\
\text { OR-2121H } \\
\text { OR-2115H } \\
\text { OR-2121H }\end{array}$ & $\begin{array}{l}402 \\
407 \\
476 \\
511\end{array}$ & $\begin{array}{l}13 \\
14 \\
15 \\
16\end{array}$ & $\begin{array}{l}5.9 \\
5.6 \\
5.3 \\
4.9\end{array}$ & $\begin{array}{l}80.0 \\
79.9 \\
79.9 \\
79.9\end{array}$ & $\begin{array}{l}\text { IRC-72 } \\
\text { IRC-72 } \\
\text { IRC-72 } \\
\text { IRC-72 }\end{array}$ & $\begin{array}{l}14 \\
92 \\
14 \\
92\end{array}$ & $\begin{array}{l}400 / 40 / 30 / 30 / 40 \\
300 / 75 / 30 / 30 / 40 \\
400 / 40 / 100 \\
300 / 75 / 85\end{array}$ & $\begin{array}{l}3.2 / 1.2 / 1.95 / 3.18 / 1.95 \\
5.3 / 1.2 / 1.95 / 3.18 / 1.95 \\
3.2 / 1.2 / 1.95 \\
5.3 / 1.2 / 1.95\end{array}$ & 1500 \\
\hline \multicolumn{10}{|c|}{${\underline{\mathrm{HRB}-8^{(3)}}}^{(3)}$} \\
\hline $\begin{array}{l}\text { OR-2121H } \\
\text { OR-2115H } \\
\text { OR-2121H } \\
\text { OR-2115H }\end{array}$ & $\begin{array}{l}402 \\
407 \\
476 \\
511\end{array}$ & $\begin{array}{l}13 \\
14 \\
15 \\
16\end{array}$ & $\begin{array}{l}7.7 \\
7.4 \\
6.9 \\
6.4\end{array}$ & $\begin{array}{l}80.4 \\
80.3 \\
80.3 \\
80.3\end{array}$ & $\begin{array}{l}\text { IRC-72 } \\
\text { IRC-72 } \\
\text { IRC-72 } \\
\text { IRC-72 }\end{array}$ & $\begin{array}{l}14 \\
92 \\
14 \\
92\end{array}$ & $\begin{array}{l}400 / 40 / 30 / 30 / 40 \\
300 / 7 / 30 / 30 / 40 \\
400 / 40 / 100 \\
300 / 75 / 85\end{array}$ & $\begin{array}{l}3.2 / 1.2 / 1.95 / 3.18 / 1.95 \\
5.3 / 1.2 / 1.95 / 3.18 / 1.95 \\
3.2 / 1.2 / 1.95 \\
5.3 / 1.2 / 1.95\end{array}$ & 1250 \\
\hline \multicolumn{10}{|c|}{${\underline{\mathrm{HRB}-9^{(4)}}}^{(4)}$} \\
\hline $\begin{array}{l}O R-2208 H \\
O R-2121 H \\
O R-2218 H \\
O R-2208 H \\
O R-2115 H \\
O R-2207 H \\
O R-2207 H\end{array}$ & $\begin{array}{l}593 \\
433 \\
486 \\
490 \\
373 \\
486 \\
486\end{array}$ & $\begin{array}{l}1 \\
3 \\
4 \\
5 \\
8 \\
9 \\
10\end{array}$ & $\begin{array}{l}4.7 \\
5.8 \\
6.3 \\
6.8 \\
7.8 \\
7.9 \\
7.9\end{array}$ & $\begin{array}{l}79.1 \\
79.5 \\
79.4 \\
79.9 \\
80.1 \\
80.1 \\
80.1\end{array}$ & IRC-72 & $\begin{array}{r}100 \\
100 \\
0 \\
100 \\
15 \\
75 \\
75\end{array}$ & $\begin{array}{l}360 / 50 / 30 / 30 / 40 \\
300 / 75 / 30 / 30 / 40 \\
360 / 50 / 30 / 30 / 40 \\
360 / 50 / 30 / 30 / 40 \\
400 / 40 / 30 / 30 / 40 \\
360 / 50 / 30 / 30 / 40 \\
360 / 50 / 30 / 30 / 40\end{array}$ & $\begin{array}{l}3.0 / 1.2 / 1.95 / 3.18 / 1.95 \\
5.3 / 1.2 / 1.95 / 3.16 / 1.95 \\
3.7 / 1.2 / 1.95 / 3.18 / 2.00 \\
3.0 / 1.2 / 1.95 / 3.18 / 1.95 \\
3.2 / 1.2 / 1.95 / 3.18 / 1.95 \\
3.0 / 1.2 / 1.95 / 3.18 / 1.95 \\
3.0 / 1.2 / 1.95 / 3.18 / 1.95\end{array}$ & 1250 \\
\hline $\begin{array}{l}\text { UR-2LUAn } \\
\text { OR-2218H } \\
\text { OR-2 2111H } \\
\text { OR-21211 } \\
\text { OR-2207II } \\
\text { OR-2115H } \\
\text { OR-211H } \\
\text { OR-2219H } \\
\text { OR-2207H } \\
\text { OR-2219H }\end{array}$ & $\begin{array}{l}48 y \\
423 \\
520 \\
398 \\
310 \\
427 \\
566 \\
584 \\
616 \\
484\end{array}$ & $\begin{array}{l}11 \\
12 \\
13 \\
14 \\
15 \\
16 \\
17 \\
18 \\
19 \\
6\end{array}$ & $\begin{array}{l}7.9 \\
7.8 \\
7.6 \\
7.2 \\
6.8 \\
6.3 \\
5.8 \\
5.3 \\
4.7 \\
7.2\end{array}$ & $\begin{array}{l}80.1 \\
80.1 \\
80.0 \\
79.9 \\
79.9 \\
80.0 \\
79.5 \\
79.3 \\
79.1 \\
80.0\end{array}$ & 1 & $\begin{array}{r}100 \\
0 \\
50 \\
100 \\
75 \\
15 \\
50 \\
\text { NA } \\
75 \\
\text { NA }\end{array}$ & $\begin{array}{l}360 / 50 / 30 / 30 / 40 \\
360 / 30 / 30 / 30 / 40 \\
360 / 50 / 30 / 30 / 10 \\
350 / 75 / 30 / 30 / 40 \\
360 / 50 / 30 / 30 / 40 \\
400 / 40 / 30 / 30 / 40 \\
360 / 50 / 30 / 30 / 40 \\
360 / 50 / 30 / 30 / 40 \\
360 / 50 / 30 / 30 / 40 \\
360 / 50 / 30 / 3 n / 40\end{array}$ & $\begin{array}{l}3.0 / 1.2 / 1.95 / 3.13 / 1.95 \\
3.9 / 1.2 / 1.95 / 3.18 / 2.00 \\
3.1 / 1.2 / 1.95 / 3.18 / 2.00 \\
5.311 .2 / 1.95 / 3.18 / 1.93 \\
3.0 / 1.2 / 1.95 / 3.18 / 1.95 \\
3.2 / 1.2 / 1.95 / 3.18 / 1.95 \\
3.1 / 1.2 / 1.95 / 3.18 / 2.00 \\
3.0 / 1.2 / 1.95 / 3.18 / 2.00 \\
3.0 / 1.2 / 1.95 / 3.18 / 1.95 \\
3.0 / 1.2 / 1.95 / 3.10 / 2.00\end{array}$ & 1 \\
\hline \multicolumn{10}{|c|}{$\underline{\text { HRB }-10}^{(4)}$} \\
\hline $\begin{array}{l}\text { OR-2208H } \\
\text { OR-2121H } \\
\text { OR-2218H } \\
\text { OR-2208H } \\
\text { OR-2115H } \\
\text { OR-2207H } \\
\text { OR-2207H } \\
\text { OR-2208H } \\
\text { OR-2218H } \\
\text { OR-2211H } \\
\text { OR-2121H } \\
\text { OR-2207H } \\
\text { OR-2115H } \\
\text { OR-2211H } \\
\text { OR-2219H } \\
\text { OR-2207H } \\
\text { OR-2219H }\end{array}$ & $\begin{array}{l}593 \\
433 \\
486 \\
490 \\
373 \\
486 \\
486 \\
469 \\
423 \\
520 \\
398 \\
510 \\
427 \\
566 \\
584 \\
616 \\
484\end{array}$ & $\begin{array}{l}1 \\
3 \\
4 \\
5 \\
8 \\
9 \\
10 \\
11 \\
12 \\
13 \\
14 \\
15 \\
16 \\
17 \\
18 \\
19 \\
6\end{array}$ & $\begin{array}{l}3.0 \\
3.7 \\
4.0 \\
4.3 \\
4.9 \\
5.0 \\
5.0 \\
5.0 \\
4.9 \\
4.8 \\
4.6 \\
4.3 \\
4.0 \\
3.7 \\
3.3 \\
3.0 \\
4.6\end{array}$ & $\begin{array}{l}77.3 \\
78.5 \\
79.2 \\
79.2 \\
79.5 \\
79.6 \\
79.6 \\
79.6 \\
79.5 \\
79.4 \\
79.3 \\
79.2 \\
79.2 \\
78.5 \\
78.0 \\
77.3 \\
79.3\end{array}$ & IRC-72 & $\begin{array}{r}100 \\
100 \\
0 \\
100 \\
15 \\
75 \\
75 \\
100 \\
0 \\
50 \\
100 \\
75 \\
15 \\
50 \\
\text { NA } \\
75 \\
\text { NA }\end{array}$ & $\begin{array}{l}360 / 50 / 30 / 3 n / 40 \\
300 / 75 / 30 / 30 / 40 \\
360 / 50 / 30 / 30 / 40 \\
360 / 50 / 30 / 30 / 40 \\
400 / 40 / 30 / 30 / 40 \\
360 / 50 / 30 / 30 / 40 \\
360 / 50 / 30 / 30 / 40 \\
360 / 30 / 30 / 30 / 40 \\
360 / 50 / 30 / 30 / 40 \\
360 / 50 / 30 / 30 / 40 \\
300 / 75 / 30 / 30 / 40 \\
360 / 50 / 30 / 30 / 40 \\
400 / 40 / 30 / 30 / 40 \\
360 / 50 / 30 / 30 / 40 \\
360 / 50 / 30 / 30 / 40 \\
360 / / 50 / 30 / 30 / 40 \\
360 / 50 / 30 / 30 / 40\end{array}$ & $\begin{array}{l}3.0 / 1.2 / 1.95 / 3.18 / 1.93 \\
5.3 / 1.2 / 1.95 / 3.18 / 1.95 \\
3.7 / 1.2 / 1.95 / 3.18 / 2.00 \\
3.0 / 1.2 / 1.95 / 3.18 / 1.95 \\
3.2 / 1.2 / 1.95 / 3.18 / 1.95 \\
3.0 / 1.2 / 1.95 / 3.18 / 1.95 \\
3.0 / 1.2 / 1.95 / 3.18 / 1.95 \\
3.0 / 1.2 / 1.95 / 3.18 / 1.95 \\
3.7 / 1.2 / 1.95 / 3.18 / 2.00 \\
3.1 / 1.2 / 1.95 / 3.18 / 2.00 \\
5.3 / 1.2 / 1.95 / 3.18 / 1.95 \\
3.0 / 1.2 / 1.95 / 3.18 / 1.95 \\
3.2 / 1.2 / 1.95 / 3.18 / 1.95 \\
3.1 / 1.2 / 1.95 / 3.18 / 2.00 \\
3.0 / 1.2 / 1.95 / 318 / 2.00 \\
3.0 / 1.2 / 1.95 / 3.18 / 1.95 \\
3.0 / 1.2 / 1.95 / 3.18 / 2.00\end{array}$ & isuo \\
\hline \multicolumn{10}{|c|}{ OF-2 $\left(C_{e} 112_{2}\right)^{(4)}$} \\
\hline $\begin{array}{l}A-611^{d} \\
A-601^{d} \\
A-611^{d} \\
A-611^{d} \\
A-601^{d} \\
A-601^{d} \\
A-611^{d} \\
A-611^{d} \\
A-601^{d} \\
A-601^{d} \\
A-611^{d} \\
A-601^{d}\end{array}$ & $\begin{array}{l}4450 \\
4440 \\
2530 \\
2530 \\
1980 \\
1980 \\
4450 \\
4450 \\
2520 \\
2520 \\
1980 \\
1980\end{array}$ & $\begin{array}{r}A-1-1 \\
-2 \\
-3 \\
-4 \\
-5 \\
-6 \\
A-2-1 \\
-2 \\
-3 \\
-4 \\
-5 \\
-6\end{array}$ & $\begin{array}{l}\text { e } \\
\text { e } \\
\text { e } \\
\text { e } \\
\text { e } \\
\text { e } \\
\text { e } \\
\text { e } \\
\text { e } \\
\text { e } \\
\text { e } \\
\text { e }\end{array}$ & $\begin{array}{l}\mathbf{f} \\
\mathbf{f} \\
\mathbf{f} \\
\mathbf{f} \\
\mathbf{f} \\
\mathbf{f} \\
\mathbf{f} \\
\mathbf{f} \\
\mathbf{f} \\
\mathbf{f}\end{array}$ & IRC-72 & $\begin{array}{l}15 \\
75 \\
15 \\
15 \\
75 \\
75 \\
15 \\
15 \\
75 \\
75 \\
15 \\
75\end{array}$ & $\begin{array}{l}360 / 50 / 35 / 30 / 35 \\
360 / 50 / 35 / 30 / 35 \\
360 / 50 / 35 / 30 / 35 \\
360 / 50 / 35 / 30 / 35 \\
360 / 50 / 35 / 30 / 35 \\
360 / 50 / 35 / 30 / 35 \\
360 / 50 / 35 / 30 / 35 \\
360 / 50 / 35 / 30 / 35 \\
360 / 50 / 35 / 50 / 35 \\
360 / 50 / 35 / 50 / 35 \\
360 / 50 / 35 / 50 / 35 \\
360 / 50 / 35 / 50 / 35\end{array}$ & $\begin{array}{l}3.0 / 1.1 / 1.7 / 33.18 / 1.7 \\
3.0 / 1.1 / 1.7 />3.18 / 1.7 \\
3.0 / 1.1 / 1.7 />3.18 / 1.7 \\
3.0 / 1.1 / 1.7 />3.18 / 1.7 \\
3.0 / 1.1 / 1.7 />3.18 / 1.7 \\
3.0 / 1.1 / 1.7 />3.18 / 1.7 \\
3.0 / 1.1 / 1.7 />3.18 / 1.7 \\
3.0 / 1.1 / 1.7 />3.18 / 1.7 \\
3.0 / 1.1 / 1.7 />3.18 / 1.7 \\
3.0 / 1.1 / 1.7 />3.18 / 1.7 \\
3.0 / 1.1 / 1.7 />3.18 / 1.7 \\
3.0 / 1.1 / 1.7 />3.18 / 1.7\end{array}$ & 1150 \\
\hline
\end{tabular}


Table 3. (Continued)

\begin{tabular}{|c|c|c|c|c|c|c|c|c|c|}
\hline $\begin{array}{l}\text { Fiasile } \\
\text { particle } \\
\text { batch } \\
\text { No. }\end{array}$ & $\begin{array}{l}\text { Number of } \\
\text { particles } \\
\text { Irradia ced }\end{array}$ & $\begin{array}{c}\text { Sample } \\
\text { Identiflcation }\end{array}$ & $\begin{array}{l}\text { Fast fluence } \\
\mathrm{E}>0.18 \mathrm{MeV} \\
\left(\mathrm{n} / \mathrm{cm}^{2}\right)\end{array}$ & $\begin{array}{l}\text { Burnup } \\
\text { (Z FIMA) }\end{array}$ & Regin & $\begin{array}{l}\text { Conversion } \\
(\boldsymbol{z})\end{array}$ & $\begin{array}{c}\text { Degign }{ }^{b} \\
A / B / C / D / E \\
(\mu m)\end{array}$ & $\begin{array}{l}\text { Denattyb } \\
\mathrm{A} / \mathrm{B} / \mathrm{C} / \mathrm{D} / \mathrm{E} \\
\left(\mathrm{g} / \mathrm{Cm}^{3}\right)\end{array}$ & $\begin{array}{c}\text { Maximum fuel } \\
\text { temperature } \\
\left({ }^{\circ} \mathrm{C}\right)\end{array}$ \\
\hline$O R-2329 H$ & 1920 & $A-3-2$ & e & $\mathrm{f}$ & IRC-72 & 0 & $375 / 20 / 35 / 30 / 35$ & $3.2 /<1.3 / 1.95 / 3.18 / 2.0$ & 1150 \\
\hline $\mathrm{OR}-2329 \mathrm{H}$ & 1920 & $A-3-4$ & e & f & & 0 & $375 / 20 / 35 / 30 / 35$ & $3.2 /<1.3 / 1.95 / 3.18 / 2.0$ & 1 \\
\hline OR-2322H & 1080 & $A-3-5$ & e & $\mathbf{f}$ & & 15 & $360 / 50 / 35 / 30 / 35$ & $3.1 /<1.3 / 1.95 / 3.18 / 2.0$ & \\
\hline OR-2211H & 1100 & $A-3-6$ & e & $\mathbf{f}$ & & so & $375 / 50 / 35 / 30 / 35$ & $3.2 /<1.3 / 1.95 / 3.18 / 2.0$ & \\
\hline OR-2208H & 1040 & $A=3-7$ & e & $\mathrm{f}$ & & 100 & $360 / 50 / 35 / 30 / 35$ & $3.0<1.3 / 1.95 / 3.18 / 2.0$ & \\
\hline$O R-2322 \mathrm{H}$ & 850 & $A-3-9$ & e & $\mathrm{f}$ & & 15 & $375 / 50 / 35 / 30 / 35$ & $3.2<1.3 / 1.95 / 3.18 / 2.0$ & \\
\hline OR-2329H & 850 & $A-3-10$ & e & f & & 0 & $375 / 20 / 35 / 30 / 35$ & $3.2<1.3 / 1.95 / 3.18 / 2.0$ & \\
\hline OR-2208H & 820 & $A-3-11$ & e & $\dot{f}$ & & 100 & $360 / 50 / 35 / 30 / 35$ & $3.0 \times 1.3 / 1.95 / 3.18 / 2.0$ & \\
\hline OR-2121K & 1520 & $A-4-1$ & e & $\mathbf{f}$ & IRC-72 & 100 & $320 / 75 / 35 / 30 / 35$ & $5.0 /<1.3 / 1.95 />3.18 / 2.0$ & \\
\hline $\mathrm{OR}-2332 \mathrm{H}$ & 1940 & $A-4-2$ & e & $\mathrm{f}$ & 2ne & 0 & $375 / 50 / 35 / 30 / 35$ & $3.2 /<1.3 / 1.95 />3.18 / 2.0$ & \\
\hline OR-2121H & 1520 & $A-4-3$ & e & $\mathbf{f}$ & & 100 & $320 / 75 / 35 / 30 / 35$ & $5.0 /<1.3 / 1.95 />3.18 / 2.0$ & \\
\hline $\mathrm{OR}-2332 \mathrm{H}$ & 1940 & $A-4-4$ & e & f & & 0 & $375 / 50 / 35 / 30 / 35$ & $3.2 /<1.3 / 1.95 />3.18 / 2.0$ & \\
\hline $\mathrm{OR}-2218 \mathrm{H}$ & 960 & $A-4-5$ & e & $\mathbf{f}$ & & 0 & $360 / 50 / 35 / 30 / 35$ & & \\
\hline $\mathrm{OR}-232 \mathrm{OH}$ & 1100 & $A-4-6$ & e & $\mathrm{f}$ & & 25 & $375 / 50 / 35 / 30 / 35$ & $3.2 /<1.3 / 1.95 />3.18 / 2.0$ & \\
\hline $\mathrm{OR}-2207 \mathrm{H}$ & 1080 & $A-4-7$ & e & $\mathbf{f}$ & & 75 & $360 / 50 / 35 / 30 / 35$ & $3.0 /<1.3 / 1.95 />3.18 / 2.0$ & \\
\hline OR-2218H & 750 & $A-4-9$ & e & f & & 0 & $360 / 50 / 35 / 30 / 35$ & $3.7 /<1.3 / 1.95 />3.18 / 2.0$ & \\
\hline OR-2332H & 860 & $A-4-10$ & e & f & & 0 & $375 / 50 / 35 / 30 / 35$ & $3.2 /<1.3 / 1.95 />3.18 / 2.0$ & \\
\hline OR-2207H & 850 & $A-4-11$ & e & f & & 75 & $360 / 50 / 35 / 30 / 35$ & $3.0 /<1.3 / 1.95 />3.18 / 2.0$ & $\mathbf{T}$ \\
\hline$A-60 L^{d}$ & 1520 & $B-1-1$ & e & $\mathbf{f}$ & IRC-72 & 75 & $360 / 50 / 35 / 30 / 35$ & $3.0 / 1.1 / 1.8 />3.18 / 1.8$ & 1350 \\
\hline$A-601^{d}$ & 1520 & $B-1-2$ & e & f & 40 & 75 & 年 & & \\
\hline $\mathrm{A}-601^{\mathrm{d}}$ & 1290 & $B-1-3$ & e & $\mathbf{f}$ & & 75 & & & \\
\hline$A-611^{d}$ & 1290 & B-1-4 & e & f & & 15 & & & \\
\hline$A-611^{d}$ & 1290 & $B-1-5$ & e & f & & 15 & & & \\
\hline$A-611^{d}$ & 1290 & $B-1-6$ & e & $\mathbf{f}$ & & 15 & & & \\
\hline$A-601 d$ & 1520 & $B-2-1$ & e & f & & 75 & & & \\
\hline$A-611^{d}$ & 1520 & B-2-2 & e & $\mathbf{f}$ & & is & & & \\
\hline$A-611^{d}$ & 1290 & B-2-3 & e & $\mathbf{f}$ & & 15 & & & \\
\hline$A-601^{d}$ & 1290 & B-2-4 & e & f & & 75 & & & \\
\hline$A-601^{d}$ & 1290 & B-2-5 & e & $\mathbf{f}$ & & 75 & & $r$ & \\
\hline$A-611^{d}$ & 1290 & $D-2-6$ & e & $\mathbf{f}$ & & 1.5 & & & \\
\hline$O R-2329 \mathrm{H}$ & $66 n$ & $\mathrm{~B}-3-2$ & e & $\mathrm{f}$ & IRC-72 & 0 & $375 / 20 / 35 / 30 / 35$ & $3.2 /<1.3 / 1.95 / \times 3.18 / 2.0$ & \\
\hline $\mathrm{OR}-2322 \mathrm{H}$ & 650 & $B-3-3$ & e & f & $\pi$ & 15. & $375 / 50 / 35 / 30 / 35$ & $3.2 /<1.3 / 1.95 />3.18 / 2.0$ & \\
\hline OR-2211H & 660 & $B-3-4$ & e & $\mathbf{f}$ & & 50 & $360 / 50 / 35 / 30 / 35$ & $3.1 /<1.3 / 1.95 />3.18 / 2.0$ & \\
\hline $\mathrm{OR}-2208 \mathrm{H}$ & 530 & $B-3-5$ & e & f & & 100 & $360 / 50 / 35 / 30 / 35$ & $3.0 /<1.3 / 1.95 / \times 3.18 / 2.0$ & \\
\hline$O R-2329 \mathrm{H}$ & 560 & $B-3-7$ & e & $\mathbf{f}$ & & 0 & $375 / 20 / 35 / 30 / 35$ & $3.2 /<1.3 / 1.95 />3.18 / 2.0$ & \\
\hline$O R-2322 \mathrm{H}$ & 550 & B-3-8 & e & $\mathbf{f}$ & & 15 & $375 / 50 / 35 / 30 / 35$ & $3.2 /<1.3 / 1.95 />3.18 / 2.0$ & \\
\hline$O R=2218 H$ & 490 & $B-3-9$ & e & $\mathbf{f}$ & & 0 & $360 / 50 / 35 / 30 / 35$ & $3.7 /<1.3 / 1.95 />3.18 / 2.0$ & \\
\hline $\mathrm{OR}-2208 \mathrm{H}$ & 530 & $\mathrm{E}-3-10$ & e & $\mathbf{f}$ & & 100 & $360 / 50 / 35 / 30 / 35$ & $3.0 /<1.3 / 1.95 />3.18 .2 .0$ & \\
\hline OR-2329H & 560 & $2-3-11$ & e & $\mathbf{f}$ & & 0 & $375 / 20 / 35 / 30 / 35$ & $3.2 /<1.3 / 1.95 />3.18 / 2.0$ & \\
\hline $\mathrm{OR}-2322 \mathrm{H}$ & 550 & $B-3-12$ & e & f & & 15 & $375 / 50 / 35 / 30 / 35$ & $3.2 /<1.3 / 1.95 />3.18 / 2.0$ & \\
\hline $\mathrm{OR}-2332 \mathrm{H}$ & 660 & $B-4-2$ & e & f & IRC-72 & 0 & $375 / 50 / 35 / 30 / 35$ & $3.2 /<1.3 / 1.95 />3.18 / 2.0$ & \\
\hline $\mathrm{OR}-2218 \mathrm{H}$ & 580 & $B-4-3$ & e & $\mathbf{f}$ & $1 .$. & 0 & $360 / 50 / 35 / 30 / 35$ & $3.7 /<1.3 / 1.95 />3.18 / 2.0$ & \\
\hline $\mathrm{OR}-2320 \mathrm{~K}$ & 660 & $B-4-4$ & e & $\mathbf{f}$ & & 25 & $375 / 50 / 35 / 30 / 35$ & $3.2 /<1.3 / 1.95 />3.18 / 2.0$ & \\
\hline OR-2207H & 550 & $B-4-5$ & e & $\mathbf{f}$ & & 75 & $320 / 75 / 35 / 30 / 35$ & $5.0 /<1.3 / 1.95 />3.18 / 2.0$ & \\
\hline OR-2121H & 440 & $B-4-6$ & e & $\mathrm{f}$ & & 100 & $320 / 75 / 35 / 30 / 35$ & $5.0 /<1.3 / 1.95 />3.18 / 2.0$ & \\
\hline OR-2332H & 560 & $B-4-7$ & e & f & & 0 & $375 / 50 / 35 / 30 / 35$ & $3.2 /<1.3 / 1.95 />3.18 / 2.0$ & \\
\hline OR-2218H & 490 & $B-4-8$ & e & $\mathbf{f}$ & & 0 & $360 / 50 / 35 / 30 / 35$ & $3.7 /<1.3 / 1.95 />3.18 / 2.0$ & \\
\hline $\mathrm{OR}-232 \mathrm{OH}$ & 560 & B-4-9 & e & f & & 25 & $375 / 30 / 35 / 30 / 35$ & $3.2 / 4.3 / 1.95 / 33.10 / 2.0$ & \\
\hline OR-2207日 & 550 & $B-4-10$ & e & $\mathbf{f}$ & & 75 & $320 / 75 / 35 / 30 / 35$ & $5.0 /<1.3 / 1.95 />3.18 / 2.0$ & \\
\hline \multirow[t]{2}{*}{$\mathrm{OR}-2332 \mathrm{H}$} & 560 & $2-4-11$ & $\mathbf{e}$ & $f$ & & 0 & $375 / 50 / 35 / 30 / 35$ & $3.2 /<1.3 / 1.95 />3.18 / 2.0$ & \\
\hline & \multicolumn{9}{|c|}{ OF-2 (Ce11 L) ${ }^{(4)}$} \\
\hline$A-601$ d & 2500 & $c-1-1$ & e & c & IRC-72 & 75 & $360 / 50 / 35 / 30 / 35$ & $3.1 / 1.1 / 1.8 /: 3.18 / 1.8$ & \\
\hline A-601d & 2500 & $c-1-2$ & e & $\mathrm{f}$ & & 75 & (5) & & \\
\hline$A-611^{d}$ & 2970 & $c-1-3$ & e & f & & 15 & & & \\
\hline$A-60 I^{d}$ & 6790 & $c-1-4$ & e & $\mathbf{E}$ & & 75 & & & \\
\hline A-6158 & 2440 & $c-2-1$ & e & $\mathrm{E}$ & & 75 & & & \\
\hline$A-6 U 1^{2}$ & 2300 & 0.28 & $:$ & $f$ & & 75 & & & \\
\hline$A-615^{B}$ & 2900 & $c-2-3$ & e & $\mathrm{f}$ & & 75 & & & \\
\hline A-61.58 & 6648 & $c-2-4$ & e & $\mathrm{f}$ & & 75 & & & \\
\hline$A-611^{d}$ & $\angle S O 0^{\circ}$ & $c-3-1$ & e & $\mathrm{f}$ & & 15 & & & \\
\hline$A-611^{d}$ & 2500 & $c-3-2$ & c & $f$ & & 15 & & & \\
\hline $\mathrm{A}-600^{\mathrm{d}}$ & 2960 & $c-3-3$ & e & $\mathrm{f}$ & & 75 & & & \\
\hline$A-611^{d}$ & 6800 & $c-3-4$ & e & $\mathbf{f}$ & & 15 & & & \\
\hline$A-6158$ & 2440 & $c-4-1$ & e & f & & 75 & & & \\
\hline$A-611^{d}$ & 2500 & $c-4-2$ & e & f & & 15 & & & \\
\hline$A-601^{d}$ & 2960 & $c-4-3$ & e & $f$ & & 75 & & & 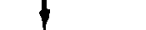 \\
\hline$A-601^{d}$ & 6790 & $c-4-4$ & e & $\mathrm{f}$ & & 75 & & & \\
\hline
\end{tabular}

apercent conversion $=\frac{2-x}{2} \cdot 100$, where $x=$ atomic fraction of oxygen in kernel; e.8., UCy00.5 $-75 z$ converted.

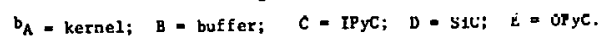

Maximum fuel design temperature.

d12.7 cm (5 1n.) diam frit.

epeak fast fluence 1111 be $8 \times 10^{21} \mathrm{n} / \mathrm{cm}^{2}$ at end of irradiation period.

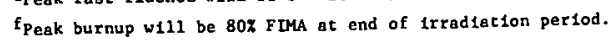

$812.7 \mathrm{~cm}(5 \mathrm{in.}) \mathrm{d} 1 \mathrm{am}$ cone.

'F. J. Homen et al., Irradiation Performance of HTCR Fuel Rode in HFIR Experiments HRB-4 and -5, ORNL-5115, In publ1cation.

2F. J. Homan et al., Iriuliulisil resfomanoo of HFrR Rual RodB in HFIR Experiment HRB-6, ORNL-TM-5011 (December 1975).

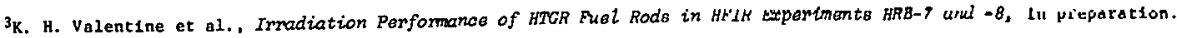

4 HTGR Base Techrology Program Anra. Progr. Rep. Jan. 1, 1974 through June 30, 1975, Sect. 6.5.3, in preparation. 
Table 3a. Results of Irradiation Tests on Weak-Acid-Resin-Derived Recyle Fuel

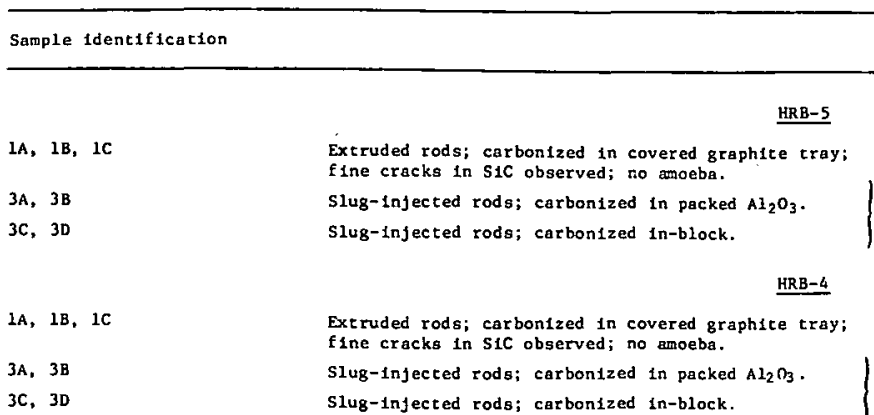

Renarks $\mathbf{a}^{2}$

104,165

$1 \mathrm{C} 6$

13

14

15

16

13

14
15

16

$1,3,4,5$

6

8

y

10

11

12

13

14

15

16

17

18

19 HRB-6

Matrix-particle interaction recognized as a potential problem with high pitch-coke ylelds. No amoeba. Kernel densification apparent. Slug-injected rods; carbonized in packed $\mathrm{Al}_{2} \mathrm{O}_{3}$

At tack of sic coating by Pd and rare-earth fisston products observed. Phase segregation in about $25 \%$ of the kernels.
Metallographic results ind fcate not all particles were 958 converted.

Loose particles in graphice tube; recovery of all particles not possible; majority fatled. Loose particles in graphlte tube; tube broke during 1rradiation; particles lost.

$\underline{\text { HRB } B-7}$

Slug-infected rod; no fallures (Metallography); buffer consumed; slight attack of SiC by rare earths. slug-infected rod; $\sim$ 50z falled (Metallography); ILTI graphit1zed by rare earths on cold side. Slug-injected rod; no fallures (Metallography); buffer consumed; phage segregation in kernel; no evidence of rare earth in coatings.

Slug-infected rod; no fallures (Metallography); unllateral movement of kernel through buffor; nn evidence of rare aarth in coatings.

\section{$\underline{\text { HRB-8 }}$}

Slug-injected rod; no failures (Metallography); buffer consumed; slight attack of SiC by rare earths. slug-injected rod; all falled (Metallography); ILTI graphitized by rare earths on cold side. Slug-injected rod; no fallures (Metallography); buffer consumed; phase segregation in kernel; no evidence of rare earth In coatings.

Slug-Infected rod; no fallures (Metallography); kernel densification apparent; buffer intact; no evidence of rare earth in coatings.

\section{$\underline{\text { HRB }-9}$}

Slug-1njected rod; stereo-exam only. No broken particles on surface.

Slug-injected rod: $220 z$ failed (Metallography): bufter in half of particles densifled and breached; cwo-phase kernel; Slug-injected rod; $220 z$ failed (Metallography): bufter in half of particles densified and breached
slight accumulation of rare earths on cold side; no graphitization of ILTI; slight accack of SiC.

slug-injected rod; no fallures (Metallography); buffer consumed; phase segregation in kernel.

Slug-injected rod; no fallures (lietallography); huffer intact; phase segregation in kernel: evidence of rare earth slug-injected rod; no fallures (Mretallography); huffer intact; phase segr
accumulation on euld slde; no graphitization of ILTf: no attack of sic

Warm-molded rud; iu caliures (Metallography); buffer intact; phase segregation in kernel; less evidence of rare earth accumulation in rod 9; no graphitization of ILTI; no attack of SiC.

Slug-injected rod; $275 x$ failed (fecallography); accumulation of rare earth on cold side; graphitization of ILTI; no attack of SiC; two-phase kernel.

Slug-1njected rod: no fallures (Metallography); amoebs through buffer; rare earths retalned in kernel; sllght attack of Sic on hot side $(2 \mu \mathrm{m})$.

slug-infected rod; no fallures (Metallography); buffer intact but densiffed around kerncl; phase segregatiun in kernel; accumilation of rare earths on coid side; no graphitization of ILT; no attack of SiC.

Slug-injected rod: $250 x$ Ealled (Metallography); phase segregation in kernel; accumulation of rare earths on cold side; graphitization of ILTI; attack of SiC $(25 \mathrm{um})$.

Slug-1njected rod; stereo-exam only; no fallures.

Slug-injected rod; no faflures (lletallography); buffer consumed; phase segregation in kernel.

Slug-injected rod; same remarks as for HRB-9, Rod 13 ( $50 \mathrm{Z}$ converted).

Slug-injected rod; stereo-exam only; no broken particles.

Slug-injected rod; stereo-exam only; no broken particles.

\section{IRB-10}

Slug-injected rod; not examined, due to reaction with thermocouple.

Slug-injected rod; stereo-exam only; no broken particles.

Slug-injected rod; stereo-exam only; no broken particles.

Slug-infected rod; $230 x$ falled (tetallography); accupulation of rare earths on cold side; graphitizarion of ILTI and buffer; attack of Sic with complete penetration.

Slug-injected rod; no failures (Metallography); buffer consumed; phase segregation in kernel.

Slug-injected rod; $28 \pi$ falled (Hetallography); phase segregartan in kernoli accumulatiun of rare earchs on cold side. slight graphit1zation of ILTI; no attack of S1C.

Harm-wolded rod; no fallures (Metallography); phase segregacion in kernel; accumulation of rare earths on cold side;
no graphitization of ILTI; slight attack of SiC. 
Table 3a. (Continued)

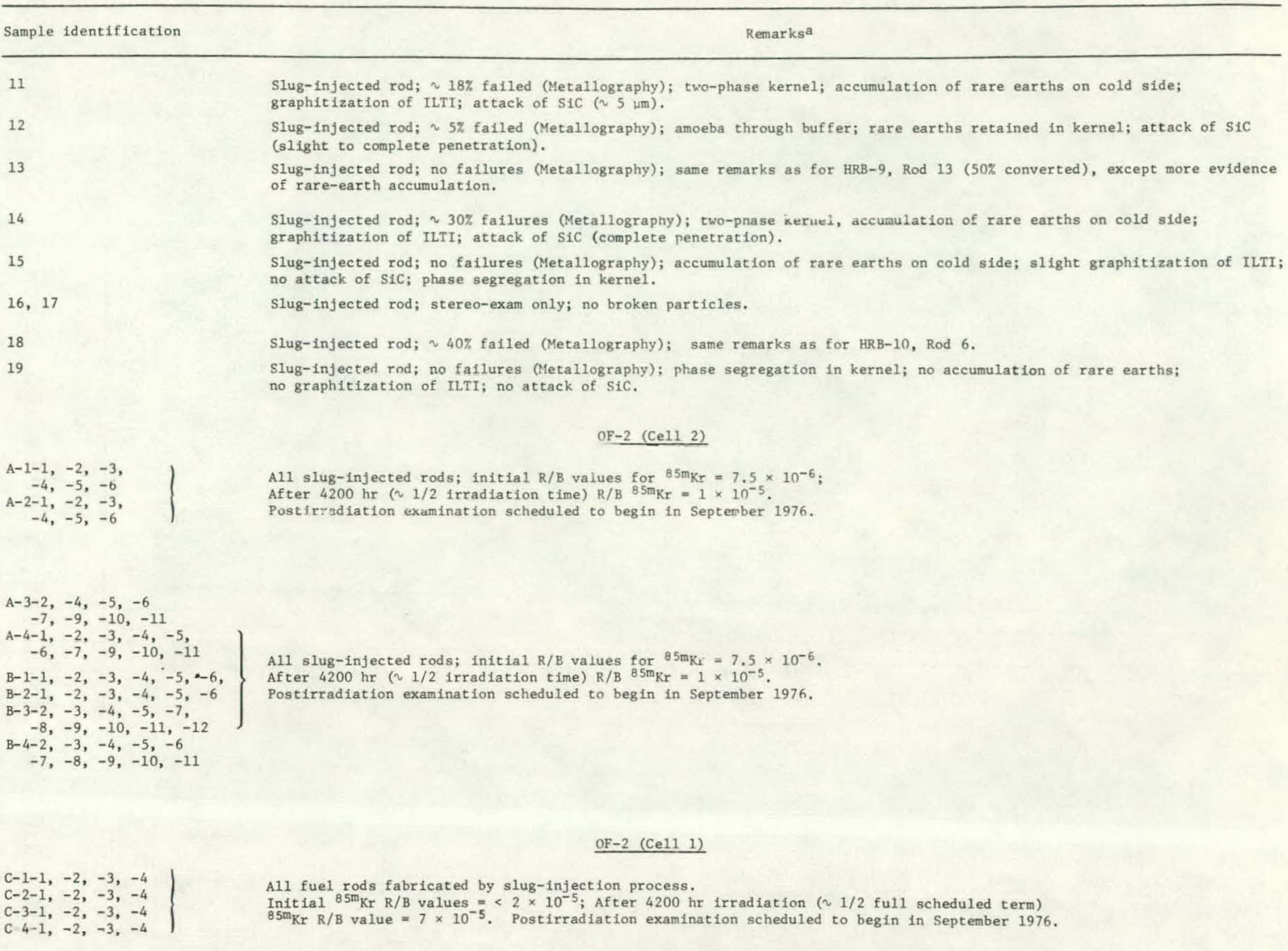

$a_{\text {References to }} \%$ falled particles" are based on failures observed in metallographic sections, and therefore are not statistically significant since normally $<20$ fissile particles are exposed in a random plane-of-polish. These results are, however, indicators of relative performance. 

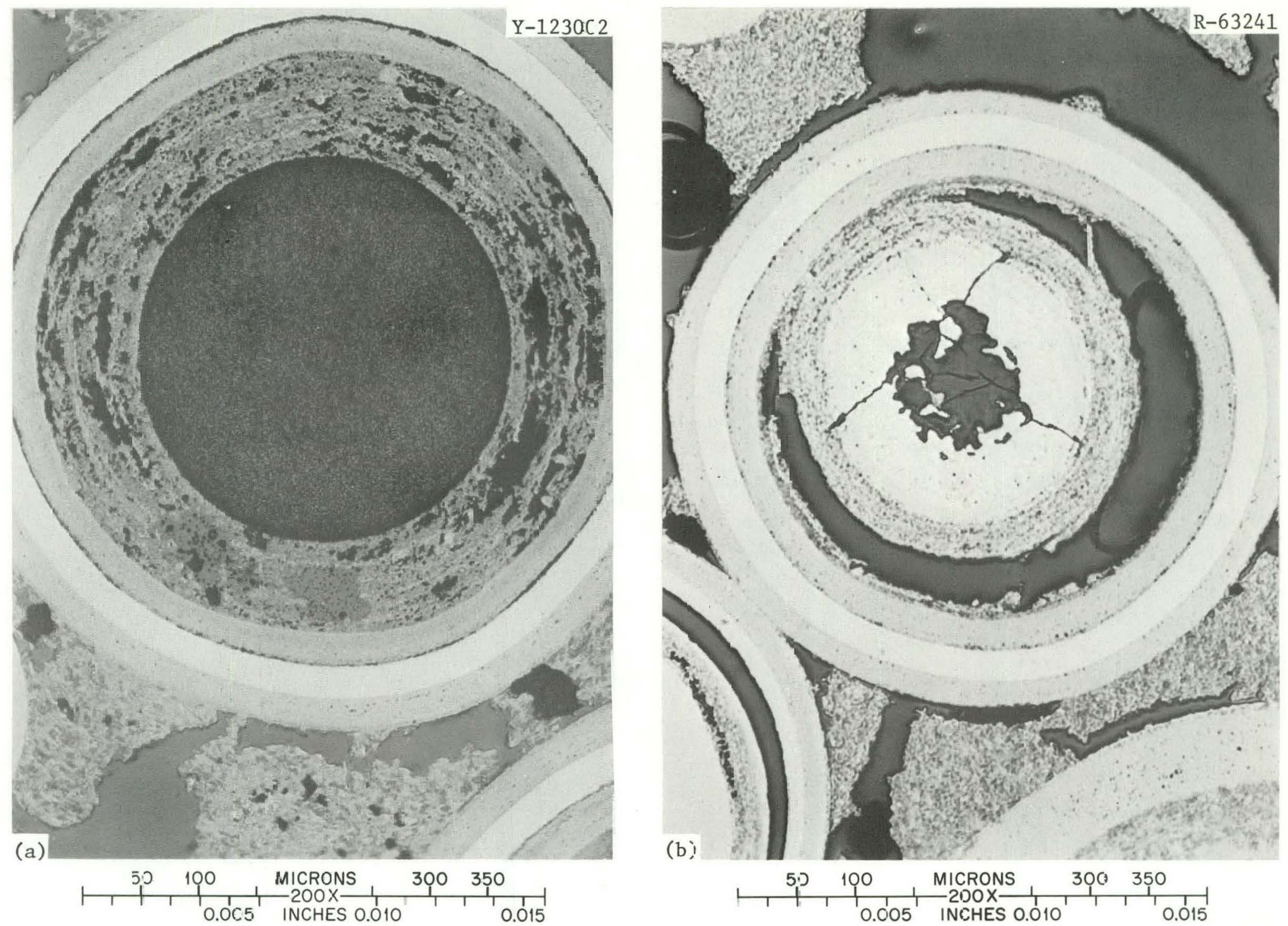

Fig. 10. Weak-Acid Resin Particles Used in Fuel Rods for Irradiation Testing. (a) Unirradiated. (b) Irradiated in $H R B-5, \operatorname{rod} 3 B$. 

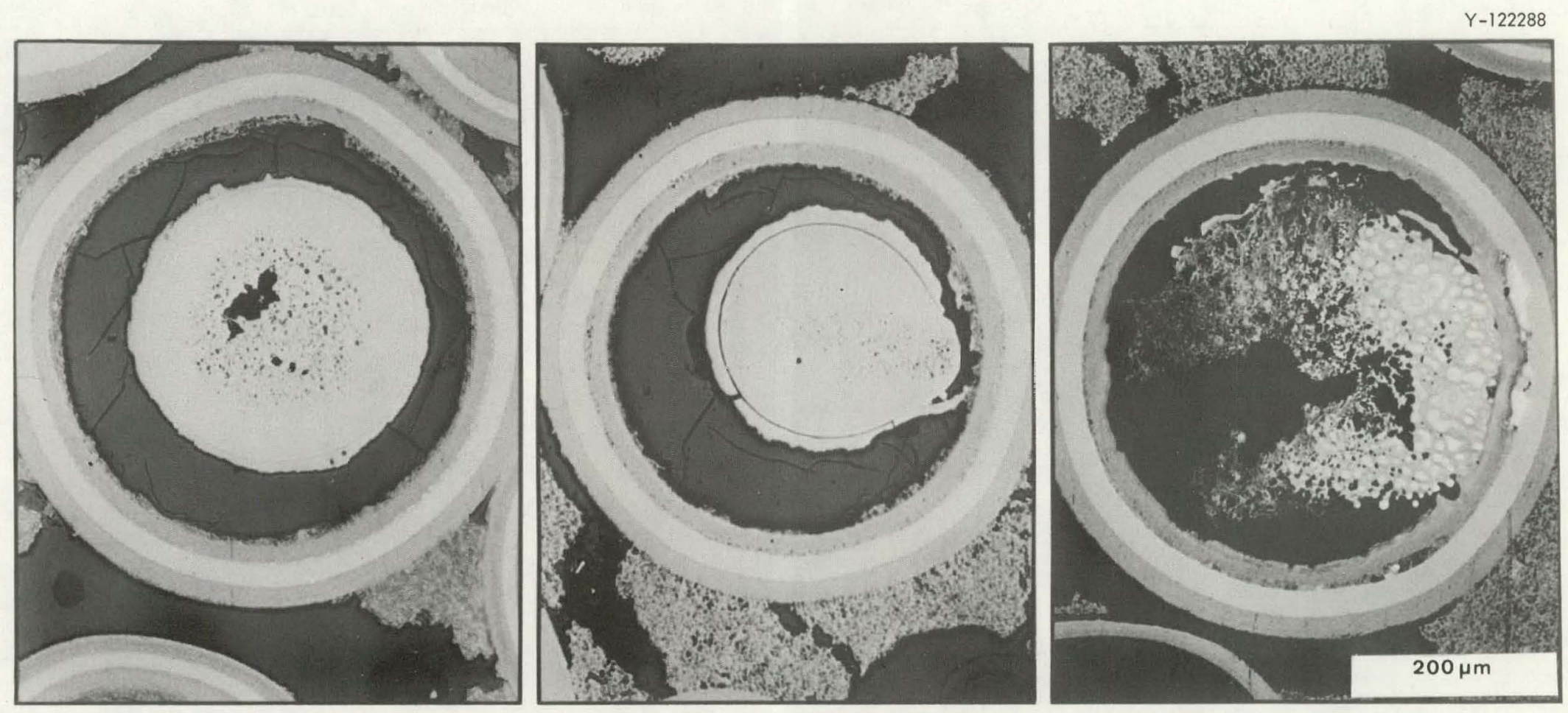

Fig. 11. Appearance of $\mathrm{NAR}^{\mathrm{U}} \mathrm{UC}_{2}$ Particles From HRB-4 Specimen 3B. Peak operating temperature, $1350^{\circ} \mathrm{C}$; burnup, $84 \%$ FIMA; fast neutron exposure, $8.9 \times 10^{21} \mathrm{n} / \mathrm{cm}^{2}(>0.18 \mathrm{MeV})$. 

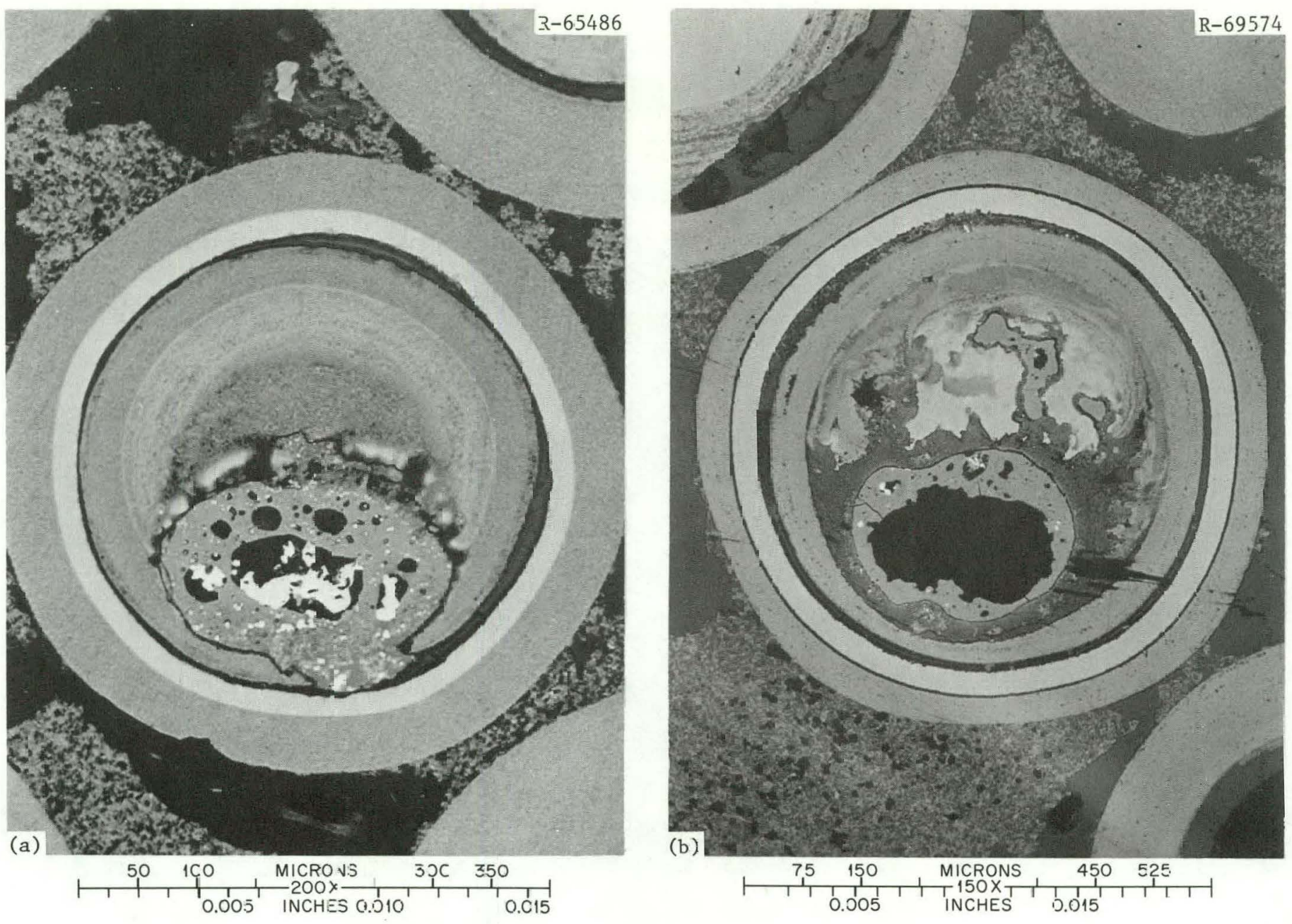

Fig. 12. Triso-Coated (a) Sol-Gel $\mathrm{UO}_{2}$ Irradiated in Rod 13 of Capsule $\mathrm{HRE}-10$ to $80 \%$ FIMA at $1300^{\circ} \mathrm{G}$ in a Temperature Gradient of $500^{\circ} \mathrm{C} / \mathrm{cm}$. (b) Weak-acid-resinderived $\mathrm{UO}_{2}$ irradiated in rod 7 of $\mathrm{HRB}-7$ to $30 \%$ FIMA at $1260^{\circ} \mathrm{C}$ in a temperature gradient of $700^{\circ} \mathrm{C} / \mathrm{cm}$. Both particles were locazed near the surface of the fuel rods and experiencel steep temperature gradients during irradiation. Note that the performance of the dense (abou= $10 \mathrm{~g} / \mathrm{cm}^{3}$ ) sol-gel kernels is about the same as the porous (about $3 \mathrm{~g} / \mathrm{cm}^{3}$ ) WAR kernels under very similar irradiation conditions. Both kernels experienced severe migration toward the hot side of the particle. 


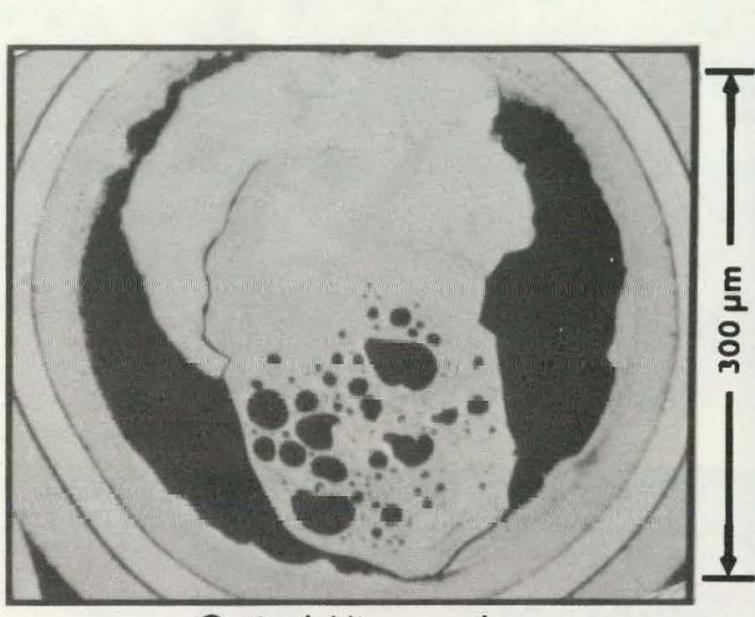

Optical Micrograph
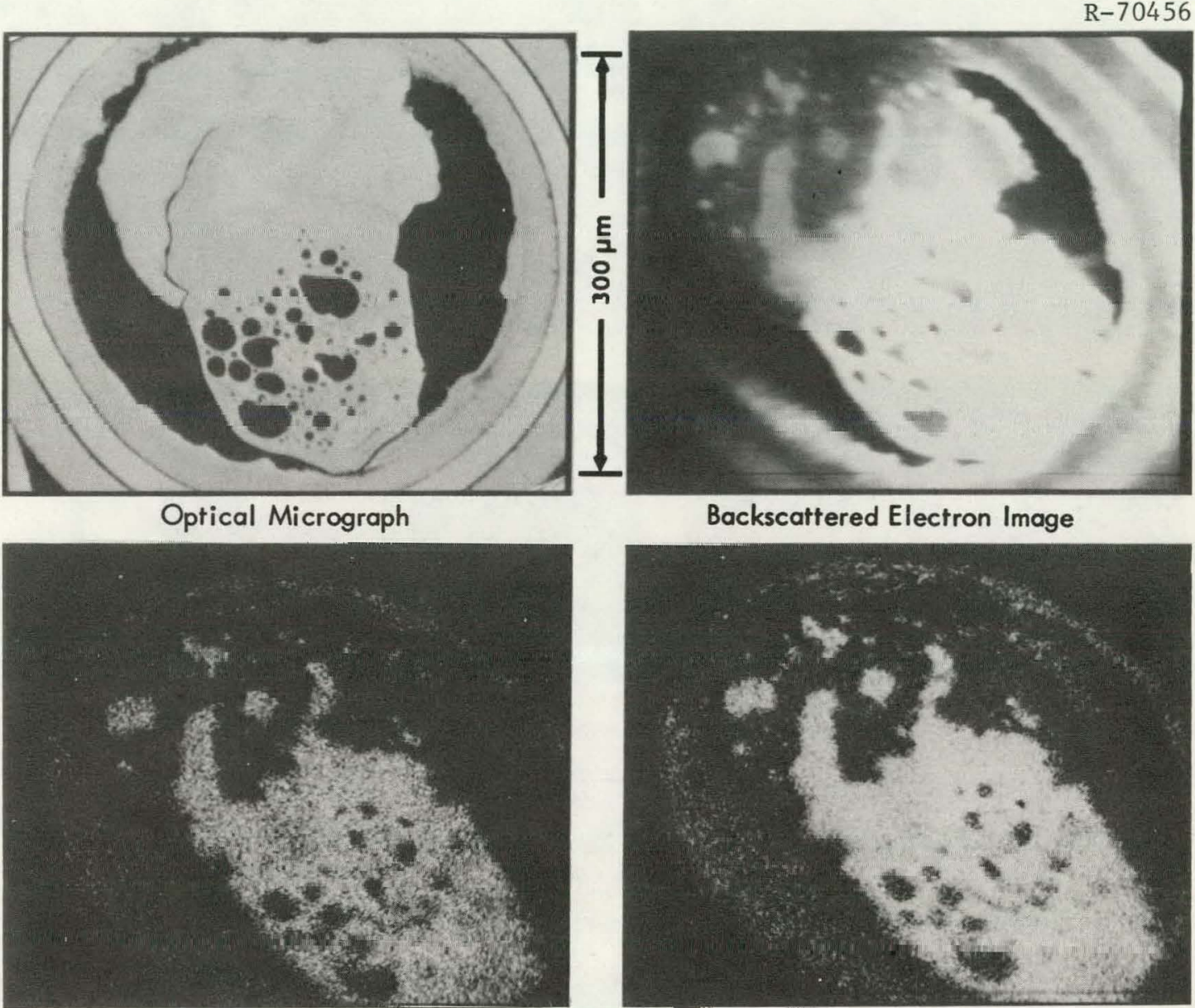

$U M \beta$

Backscattered Electron Image

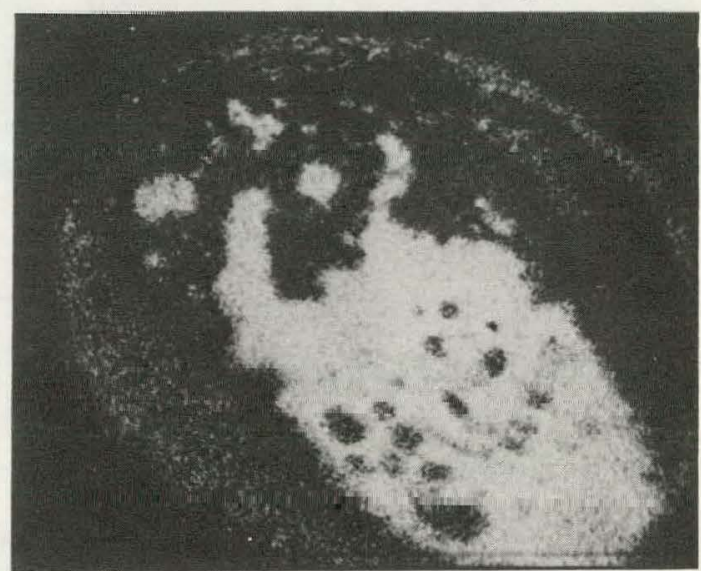

Nd La

Fig. 13. Distribution of Uranium and Rare-Earth Fission Products (Represented by Neodymium X-Ray Display) in a $15 \%$-Converted Weak-AcidResin-Derived Particle. There is no indication that the neodymium penetrated the inner pyrocarbon layer. The neodymium display is representative of cerium, praseodymium, and lanthanum. 


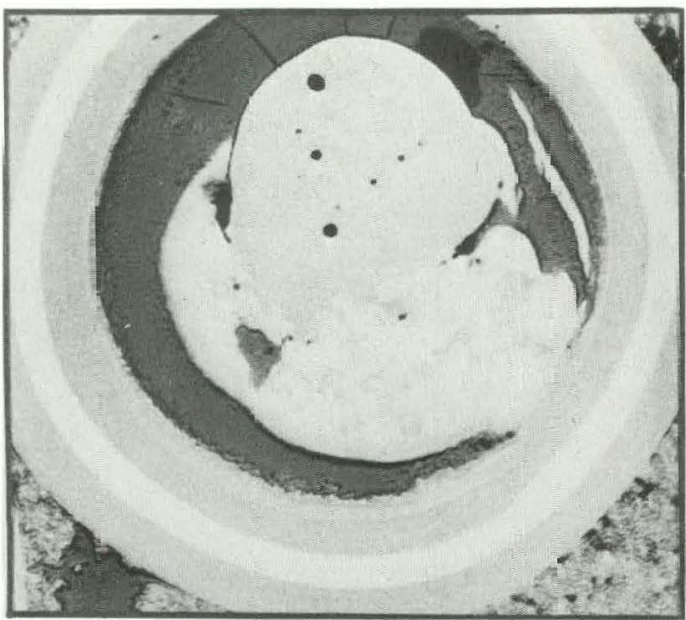

Optical Micrograph

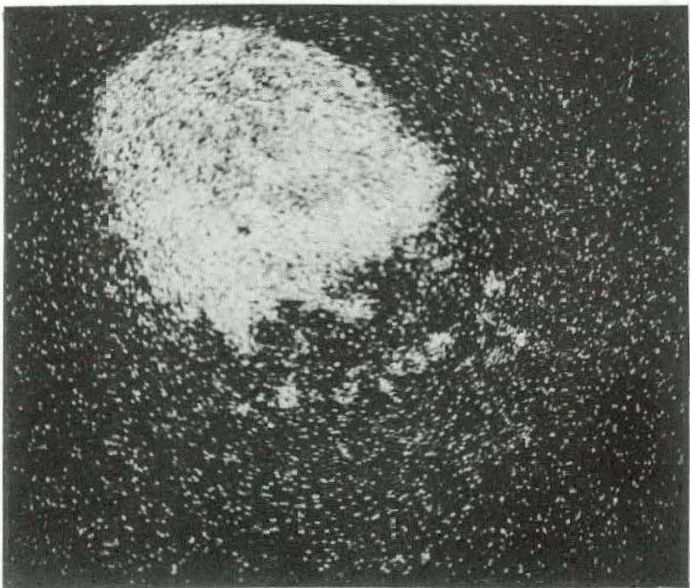

UMB

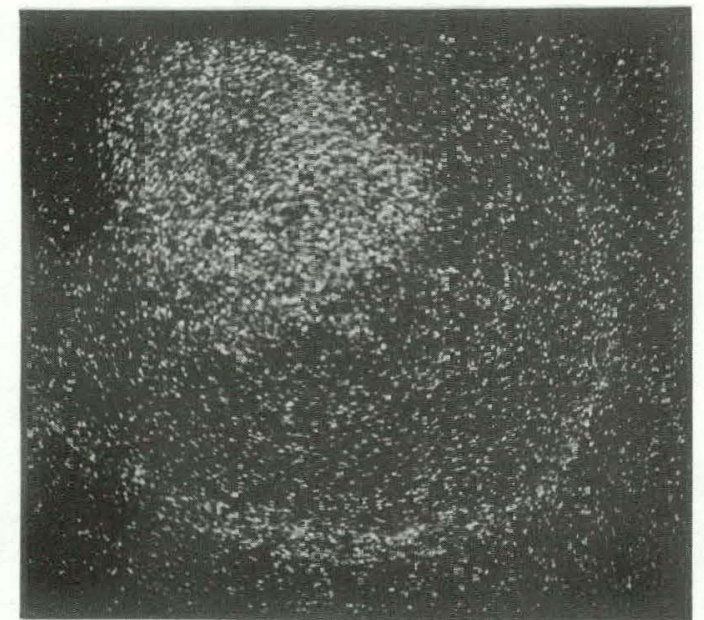

$L_{a} L_{\alpha}$

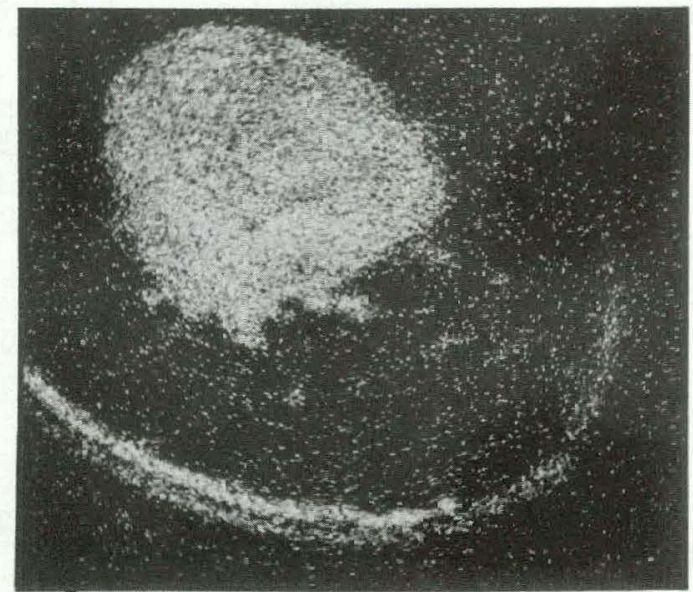

$C e-a$

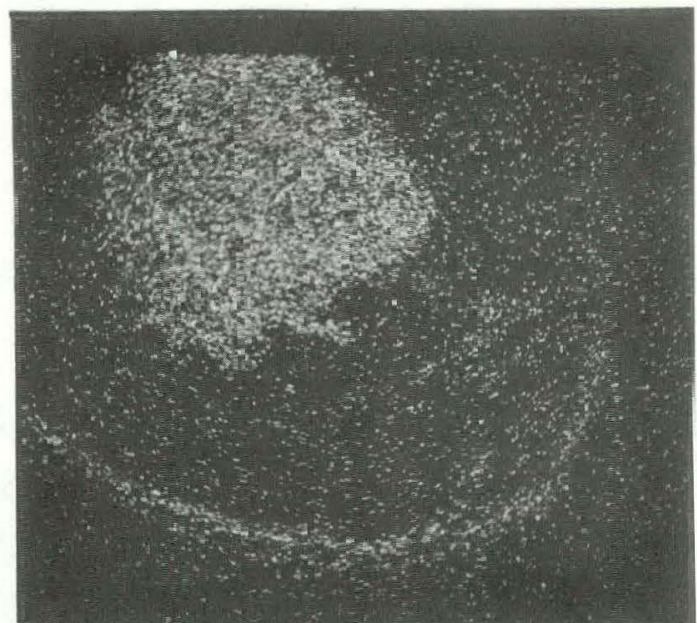

$\operatorname{Pr} L_{x}$

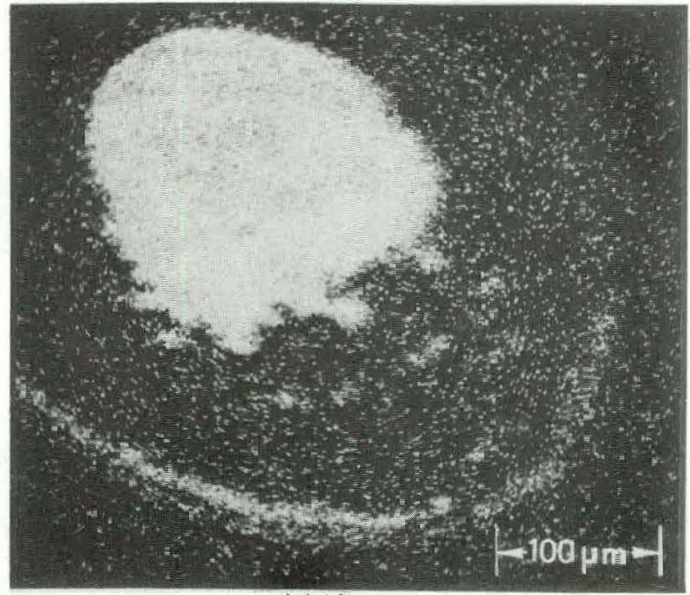

$\mathrm{NdL} \mathrm{L}_{\sigma}$

Fig. 14. Distributicn of Uranium and Rare-Earth Fission Products in a Triso-Coatec 15\%-Reduced WAR Particle Irradiated in HRB-8. 
retained in the kernel. Optical metallography and shielded microprobe displays of fuel irradiated in the HRB-4 capsule are shown in Fig. 15. This fuel was nominally $95 \% \mathrm{UC}_{2}$. A similar display for reference fresh fissile fuel $\left(\mathrm{UC}_{2}\right)$ irradiated under real-time conditions in the Peach Bottom Reactor is shown in Fig. 16. It is emphasized that the $\mathrm{UC}_{2}$ shown in Fig. 16 has been irradiated to less than $20 \%$ full burnup and fastneutron exposure expected for the large HTGR. ${ }^{19}$ Both WAR $\mathrm{UC}_{2}$ and dense $\mathrm{UC}_{2}$ performed similarly in fuel irradiated in $\mathrm{HRB}-7$ (Fig. 17). The polarized light portion of this figure reveals the areas of fission product attack as bright areas, indicating a high degree of optical activity.

5. There is a considerable temperature gradient effect on the fission product attack discussed above. Under high-temperature gradients the fission products are concentrated on the cold side of the particle, and failure of the silicon carbide layer is likely, as shown on the left side of Fig. 18. Under less severe temperature gradients, the fission products are less concentrated and do less damage. The particle shown on the right side of Fig. 18 operated at the center of the same fuel rod as the particle on the left. The temperature gradient is zero at the center of the rod, and even though the operating temperature was higher, less damage was done to the coatings by the fission products. The bottom portion of the figure, in polarized light, shows the fission products as light regions. The temperature gradient of $1000^{\circ} \mathrm{C} / \mathrm{cm}$ is about $30 \%$ higher than the maximum temperature gradient shown for a large HTGR in Table 1.

Fission product attack of the coatings appears to be the limiting performance feature of $\mathrm{WAR}_{\mathrm{UC}}$ fuels. Thermal migration appears to be limiting for $\mathrm{WAR}^{\mathrm{UO}_{2}}$. Intermediate compositions appear to do well compared with these extremes. In the HRB-7 through -10 experiments, WAR fissile fuels with conversion levels of $0,15,50,75$, and $100 \%$ were tested (Fig. 19). These WAR kernels had reference Triso* coatings and were fabricated into fuel rods using the slug-injection ${ }^{20}$ technique. As indicated earlier, the $\mathrm{WAR}^{\mathrm{UO}_{2}}$ kernel has migrated up the temperature gradient. The WAR $\mathrm{UC}_{2}$ particle shown has failed from fission product attack of the silicon carbide layer. Figure 20 shows an optical photomicrograph of a WAR $\mathrm{UC}_{2}$ particle irradiated in $\mathrm{HRB}-8$. Also shown are electron microprobe displays for the rare earth fission products La, $\mathrm{Pr}, \mathrm{Ce}$, and $\mathrm{Nd}$. The graphitization of the inner low-temperature isotropic layer and failure of the silicon carbide in the regions occupied by the fission products suggest that fission product interaction with the silicon carbide coating caused the failure.

*The reference Triso design calls for four coatings applied to the kernel. The first coating is called the buffer, and is a porous (about $50 \%$ dense) layer of pyrolytic carbon. The next coating is called the inner low-temperature isotropic (ILTI) layer, which is dense pyrolytic carbon (about $85 \%$ dense). The third layer is silicon carbide of near theoretical density. The fourth layer is the outer low-temperature isotropic (OLTI) layer, which is similar to the ILTI. These layers are applied to retain fission products. 


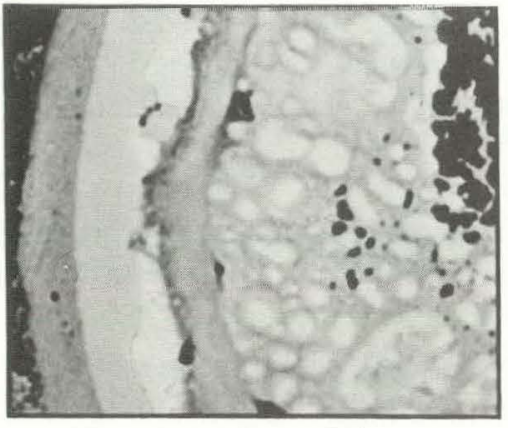

Optical Photograph

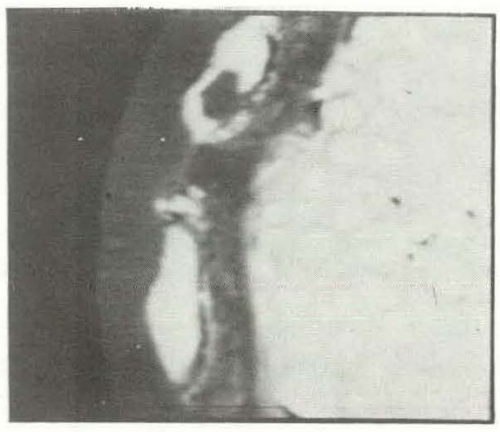

Backscattered Electrons

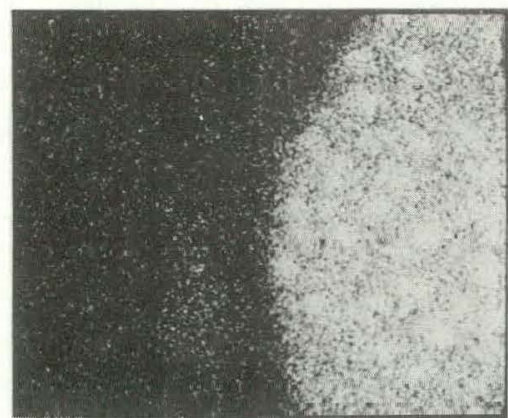

U Ma

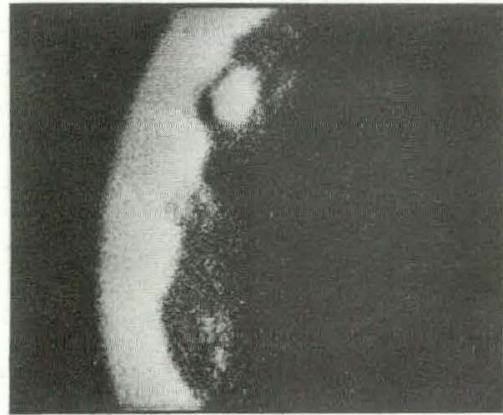

Si La

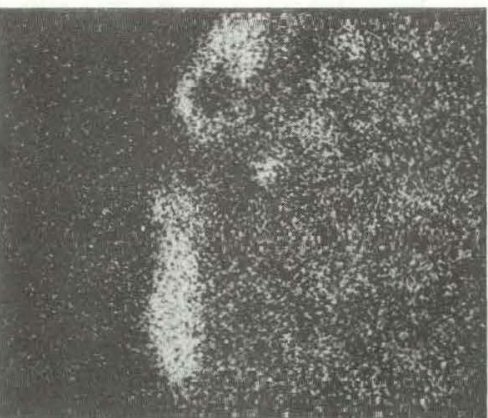

LaLa

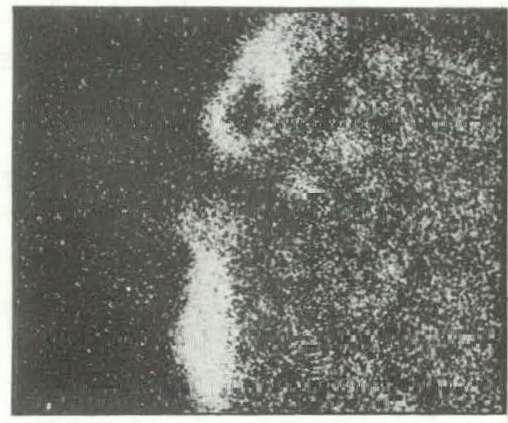

Ce La

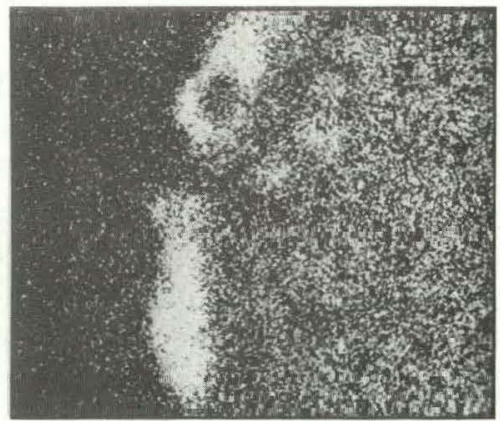

$\operatorname{Pr} L_{\alpha}$

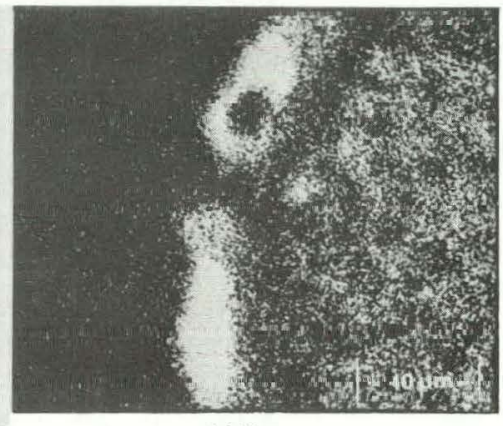

$\mathrm{NdLa}$

Fig. 15. Weak-Acid-Resin $\mathrm{UC}_{2}$ Particle from Capsule HRB-4. Peak operating temperature, about $1350^{\circ} \mathrm{C}$; burnup, about $84 \% \mathrm{FIMA}$; fast neutron exposure, about $8.9 \times 10^{21} \mathrm{n} / \mathrm{cm}^{2}(>0.18 \mathrm{MeV})$. 


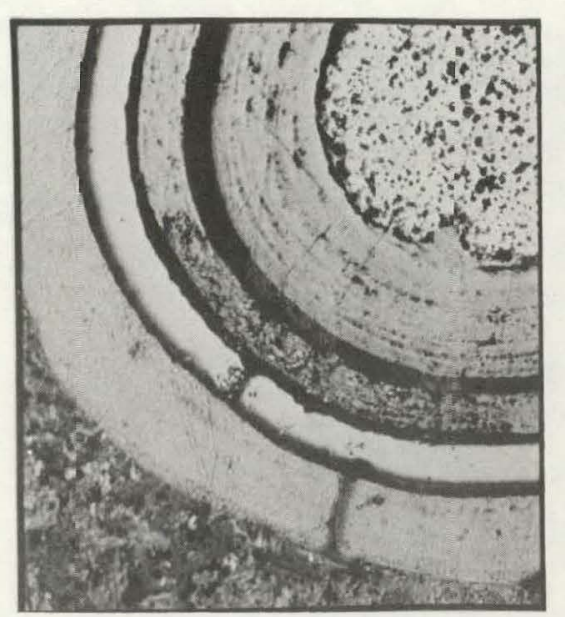

Optical Micrograph

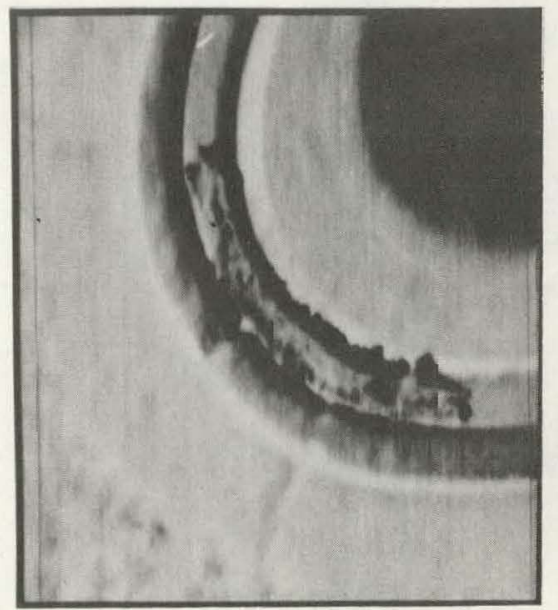

Backscattered Electrons

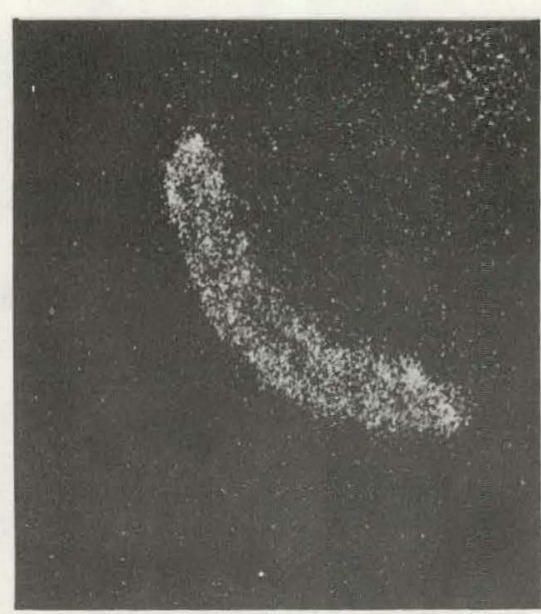

La $L_{\alpha}$

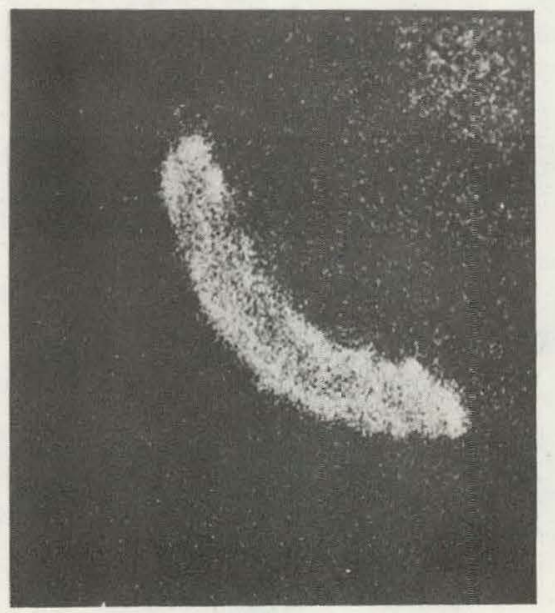

Ce La

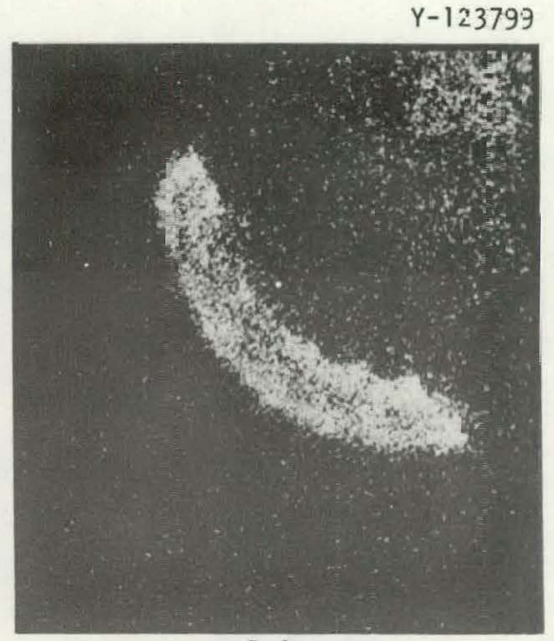

$\operatorname{Pr} L_{\alpha}$

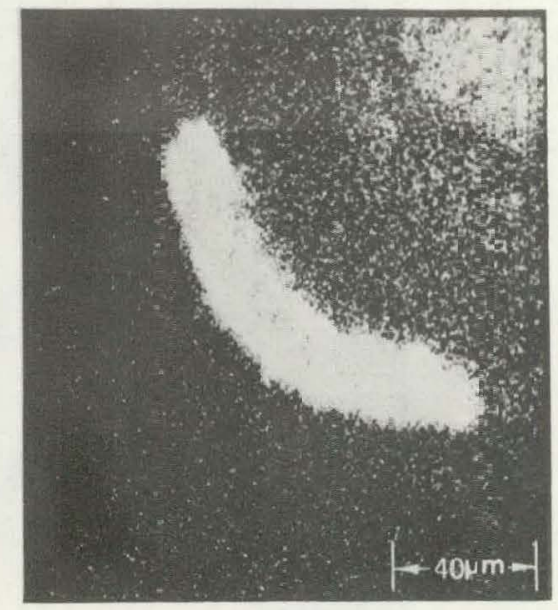

Nd La

Fig. 16. Rare-Earth Fission Product Attack cf Coating Layers has Caused Failure of This Triso-Coated Dense $\mathrm{UC}_{2}$ Particle from RTE-4. This particle was irradiated in the Peach Bottom Reactor to less than $20 \%$ of the burnup and nectron exposure anticipated in a commercial HTGR at an irradiation temperature of less than $1200^{\circ} \mathrm{C}$. 

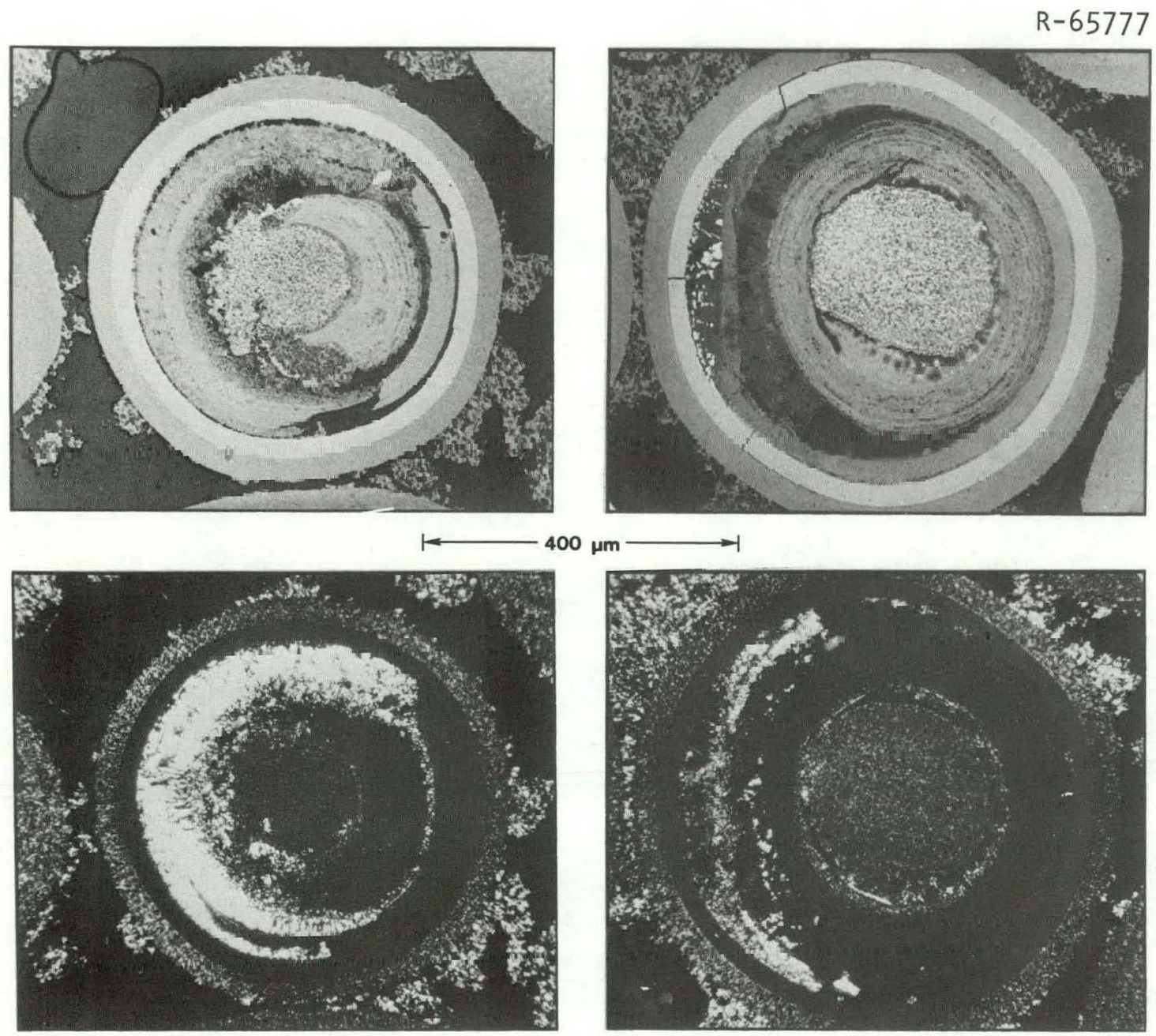

Fig. 17. Relative Performance of Dense Melted (VSM) $\mathrm{UC}_{2}$ and WAR $\mathrm{UC}_{2}$ in Irradiation Capsule HRB-7. Top: bright field. Bottom: polarized light. Left: dense $\mathrm{UC}_{2}$. Right: WAR $\mathrm{UC}_{2}$. 
IEMPERATURE: $1100^{\circ} \mathrm{C}$ THERMAL GRADIENT: $1000^{\circ} \mathrm{C} / \mathrm{cm}$
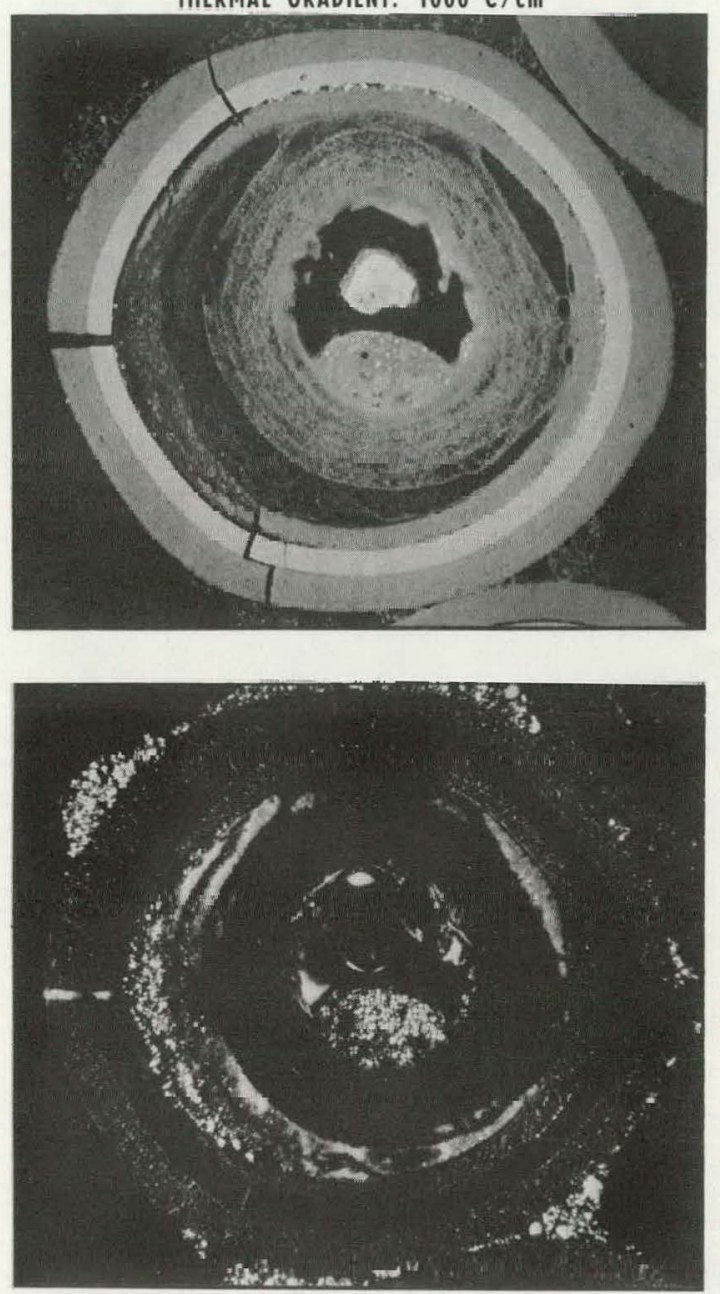

Fig. 18. Effect of Thermal Gradient on Distribution of Rare-Earth Fission Products in a Triso-Coated $100 \%$-Converted WAR $\mathrm{UC}_{2}$ Kernel. Top: bright field. Bottom: polarized light.
TEMPERATURE: $1250^{\circ} \mathrm{C}$

$R-70446$ THERMAL GRADIENT: $0^{\circ} \mathrm{C} / \mathrm{cm}$

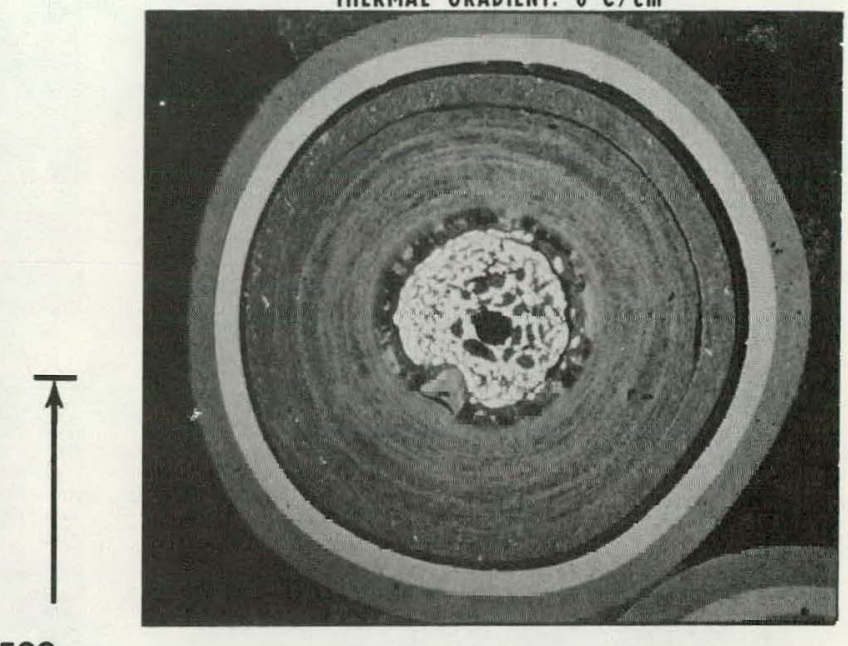

$500 \mu \mathrm{m}$
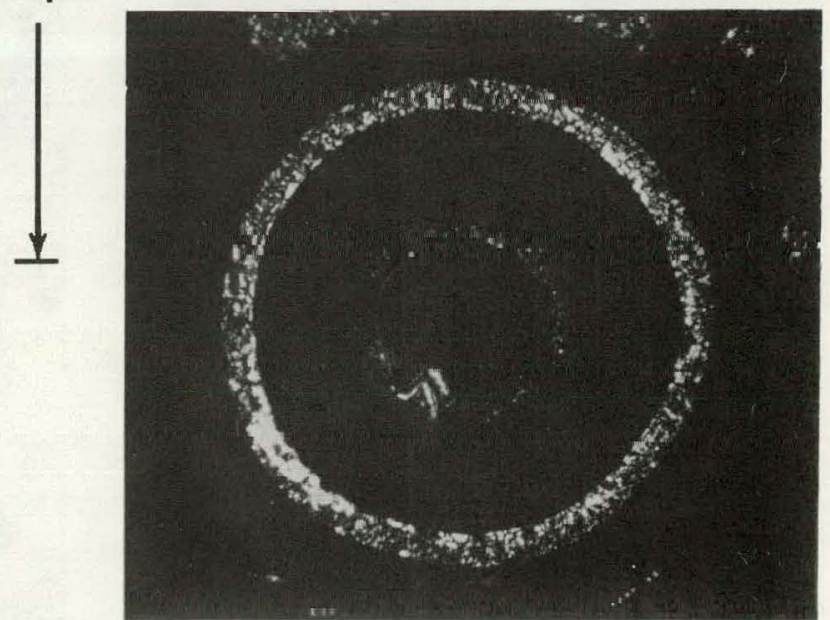


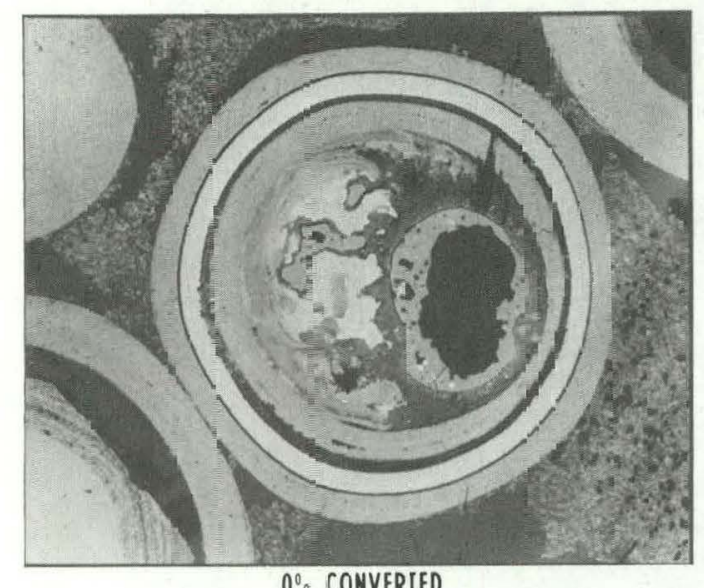

$O^{\circ}$ a CONVERIED

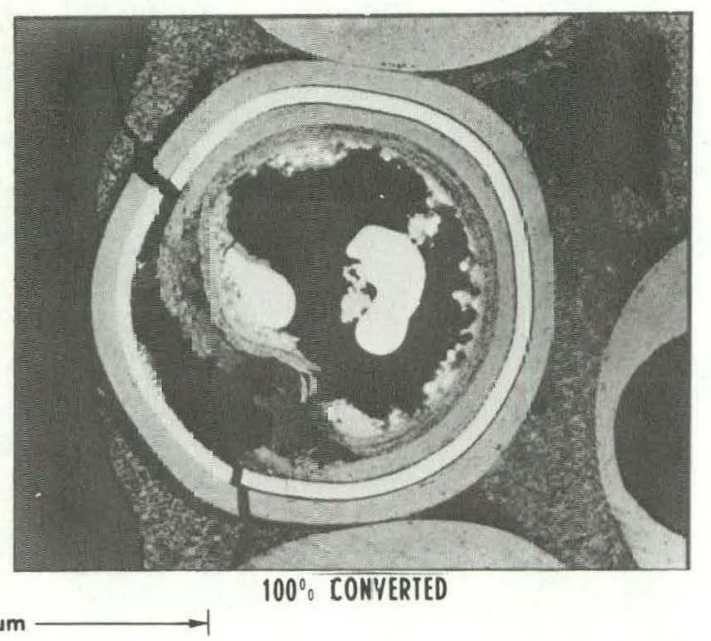

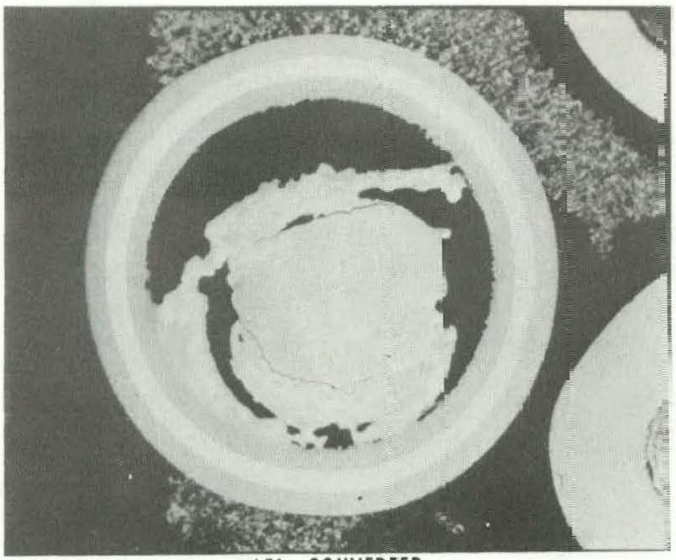

$15^{\circ}$ CONVERIED
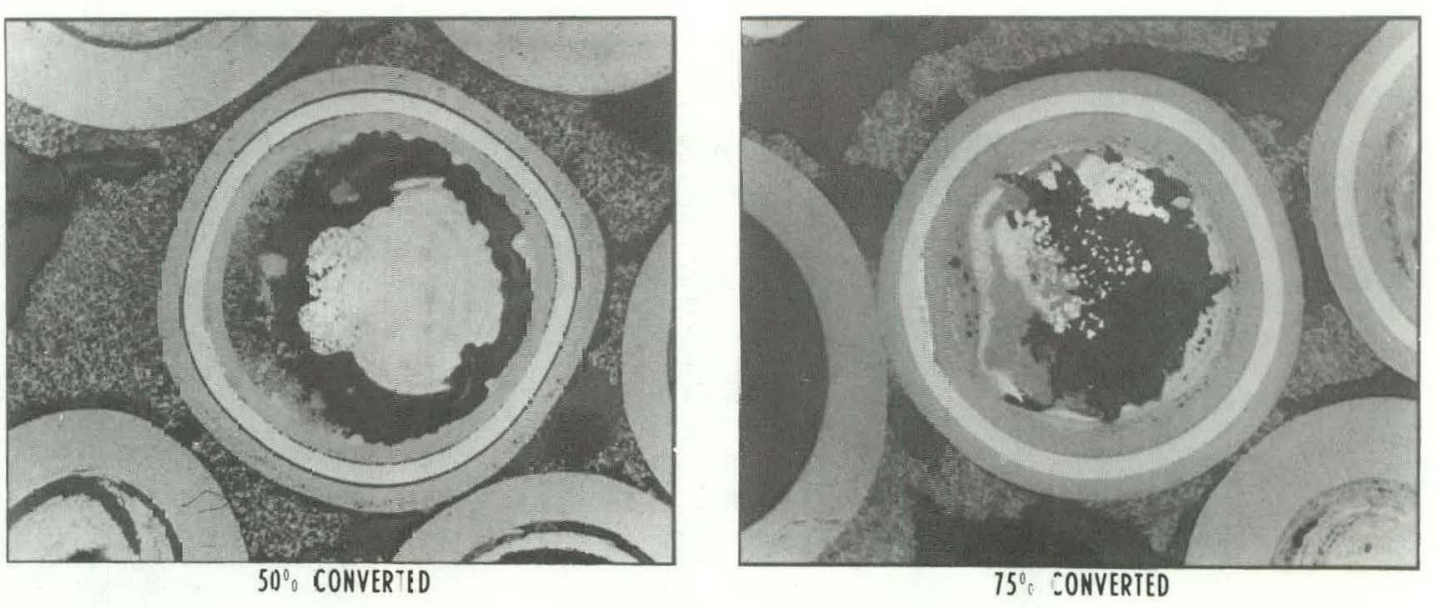

Fig. 19. Relative Performance of WAF Kernels Within the Range of $\mathrm{UO}_{2}\left(0 \%\right.$ Converted) to $\mathrm{UC}_{2}$ (100\% Converted). Irradiazed at a naximur fuel temperature of $1500^{\circ} \mathrm{C}$ to a burnup of $80 \%$ FIMA. Fast fluence ranged from $\dot{4} .3$ to $5.0 \times 10^{21} \mathrm{n} / \mathrm{cr}^{2}(>0.18 \mathrm{MeV})$. The hot side of the particles is on the right. 


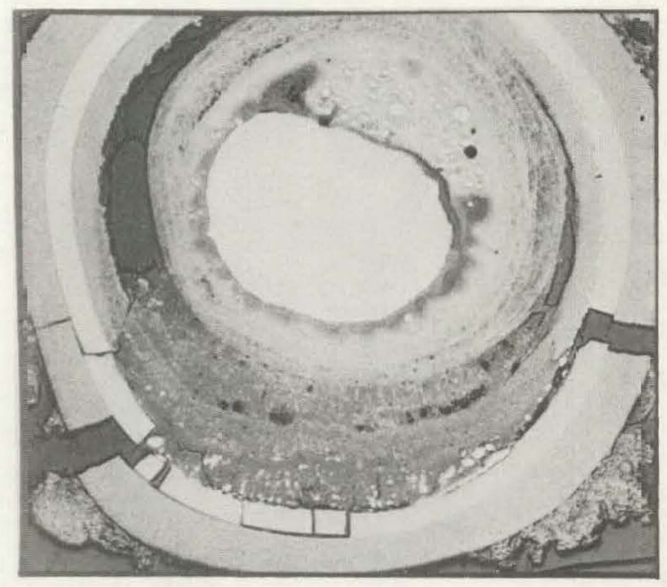

Optical Micrograph

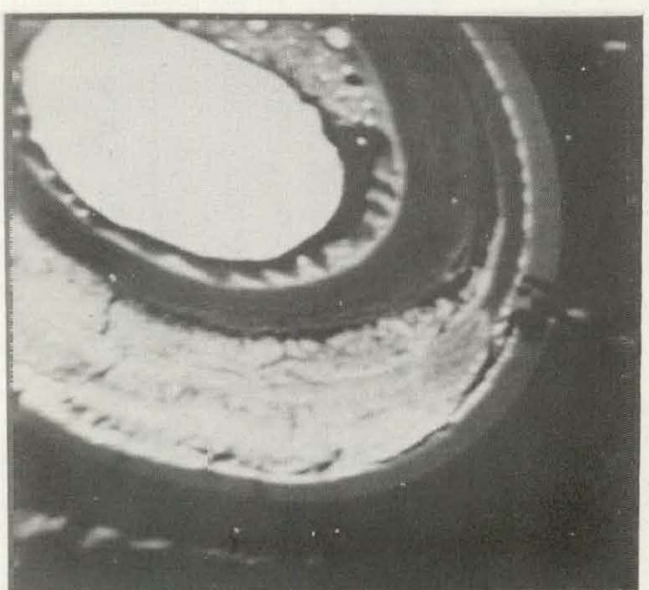

Backscattered Electron Image

Fig. 20

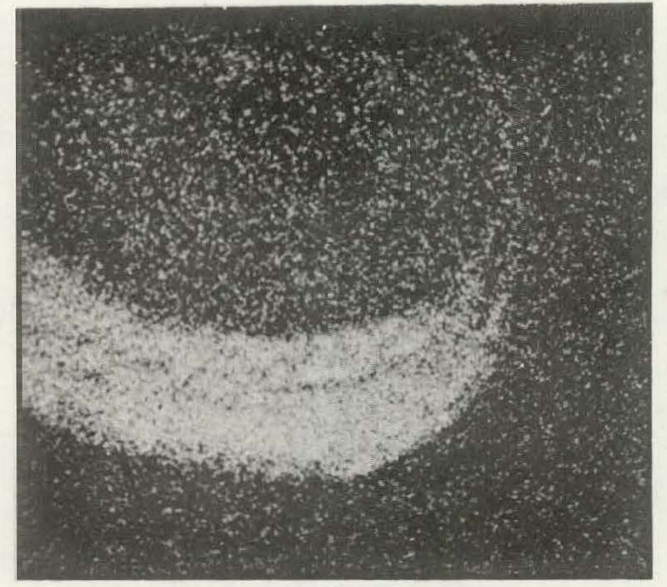

La La

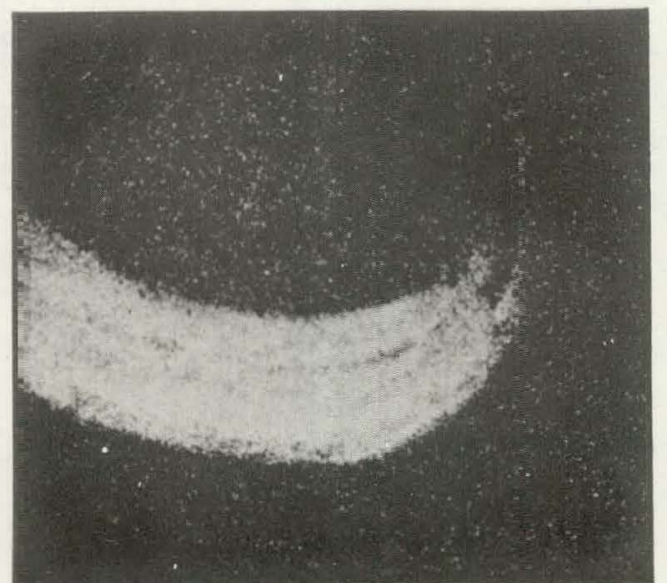

Ce La

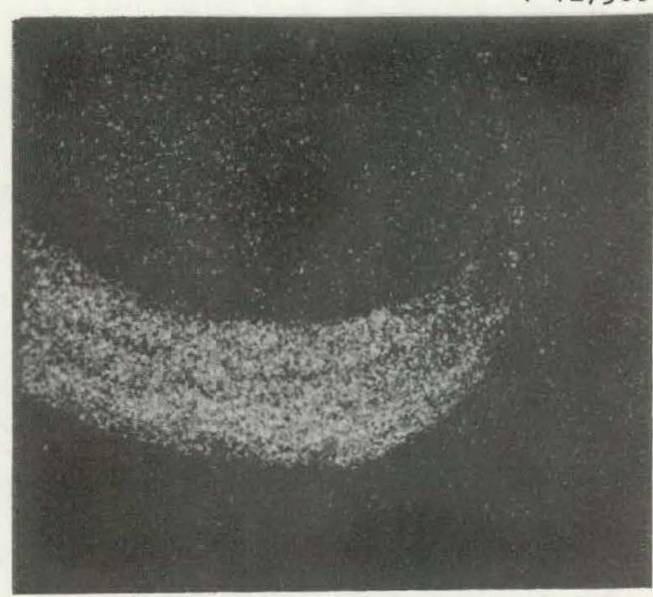

Pr La

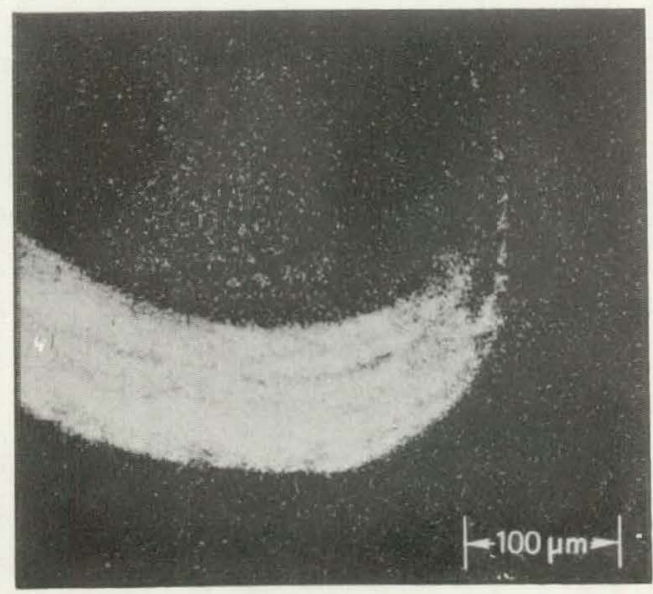

$\mathrm{Nd} \mathrm{L}_{a}$ 作 and $990^{\circ} \mathrm{C} / \mathrm{cm}$. Note that rare earths have left the kernel and collected at the inner surface of the SiC layer, causing extensive damage to both the inner LTI and SiC layers. 
We calculated (see following section) the amount of $\mathrm{UO}_{2}$ necessary to retain the rare earth fission products in the form of oxides in WAR fuels irradiated to full burnup (about 75\% FIMA*). The irradiation results from $\mathrm{HRB}-7$ through -10 support the conclusions reached in these calculations. The $\mathrm{UO}_{2}$ fuel retains all the rare earth fission products in the kernel since the oxides are stable (Fig. 21). The $15 \%$-converted WAR fuel (Figs. 13 and 14 ) also retained most of the rare earth fission products within the kernel. As the amount of $\mathrm{UC}_{2}$ in the kernel is increased, the capacity to hold the rare earth fission products within the kernel is reduced (Figs. 22 and 23). Neodymium accumulates slightly at the inner surface of the SiC layer for the $50 \%$-converted fuel (Fig. 22). However, most of the neodymium has been retained in the kernel. The neodymium display represents the rare earth fission products. In Fig. 23 higher magnification views of the cold side of coatings for the 15, 50, and 75\%-converted fuels shown in Fig. 19 are shown. Slight accumulations of fission products, believed to be rare earths, can be seen at the silicon carbide inner low-temperature isotropic-layer interface for the particles with 50 and 75\%-converted kernels. As noted above, the amount of fission product accumulation at the inner surface of the SiC layer increases with the percentage of $\mathrm{UC}_{2}$ present in the kernel.

The optimum kernel composition for WAR fuels has not yet been determined. Experiments now in-reactor are designed to establish the optimum $\mathrm{UO}_{2}$ content. The results from $\mathrm{HRB}-7$ through -10 , and the thermodynamic calculations, suggest an optimum value of about $35 \%$ conversion, with a permissible range of $\pm 20 \%$.

The argument against high $\mathrm{UC}_{2}$ content is clear. Some problems in addition to amoeba have also been encountered with high $\mathrm{UO}_{2}$ content. While no fission product attack of the silicon carbide layer was noted with the WAR $\mathrm{UO}_{2}$ fuel, there was some evidence of oxidation of the inner surface of the silicon carbide layer (Fig. 24). The attack was moderate for fuel temperatures of about $1250^{\circ} \mathrm{C}$, but at about $1500^{\circ} \mathrm{C}$ the silicon carbide was completely penetrated. Very slight oxidation was noted when fuel of this same composition was irradiated in capsule $\mathrm{HRB}-9$ with a design centerline temperature of $1250^{\circ} \mathrm{C}$.

From the processing standpoint, it is desirable to maximize the $\mathrm{UO}_{2}$ content in the two-phase WAR kernels. Therefore, considerable effort has been made to understand the behavior of the $15 \%$-converted fuel, which is currently thought to be the lower limit for the conversion specification. Phase segregation (Figs. 13 and 14) is apparent both from the optical examination and from microprobe work. The uranium-bearing phase is retained within the outer boundary of the buffer layer. The work done to date on $15 \%$-converted fuel indicates that the buffer layer is largely incorporated into the kernel.

$*_{\text {FIMA }}=$ Fissions per Initial Metal Atom. 


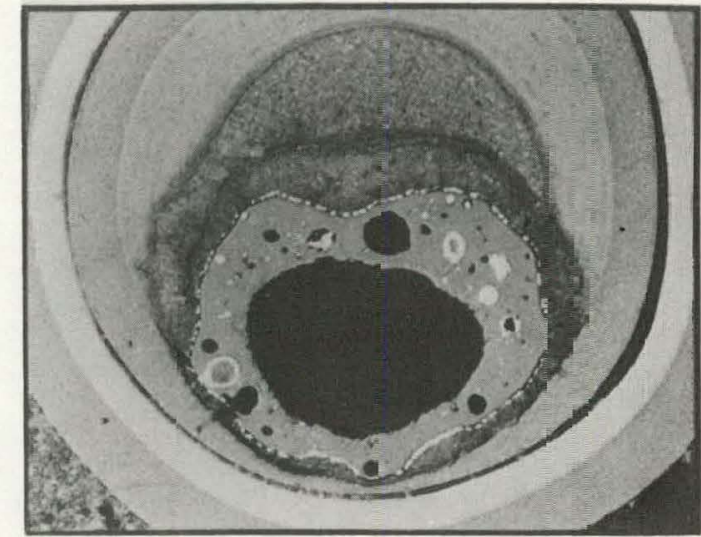

Optical Micrograph

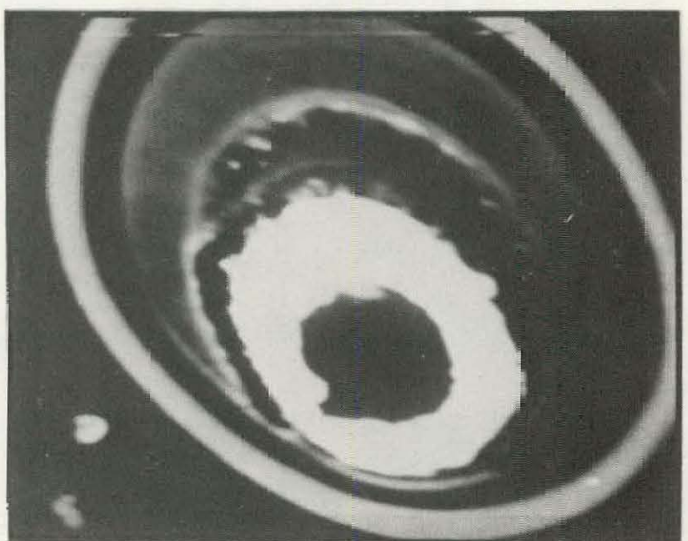

Sample Current Image

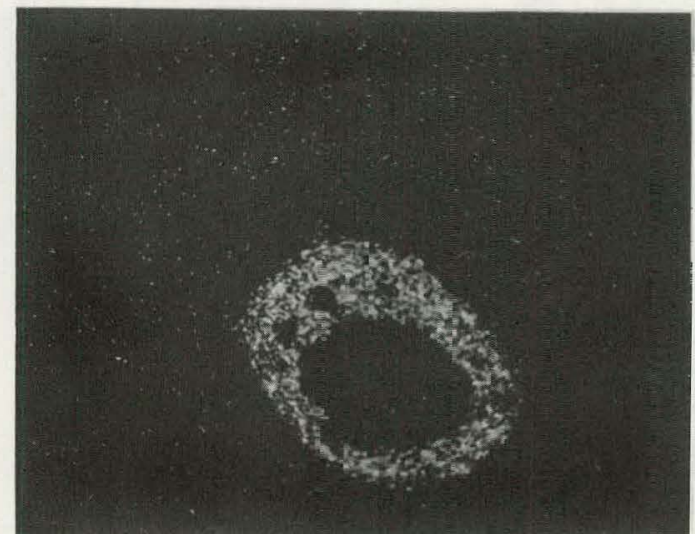

La La

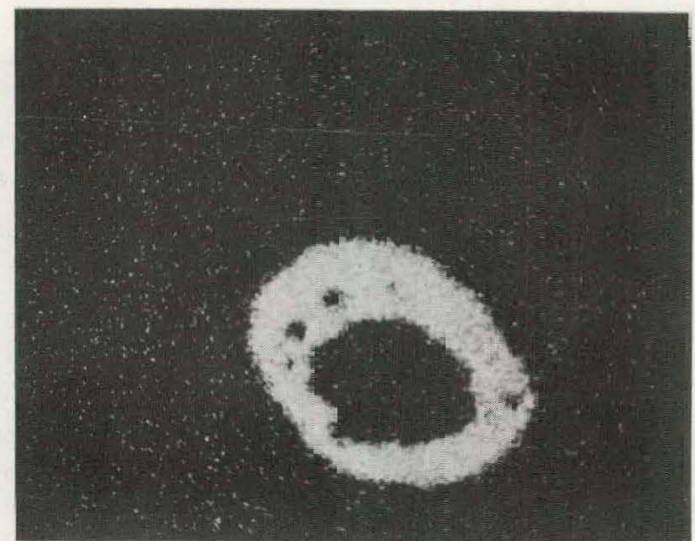

Ce La

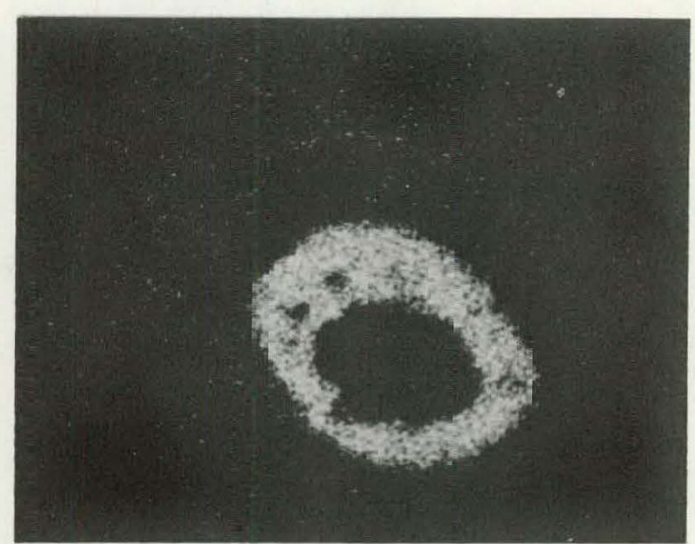

Pr La

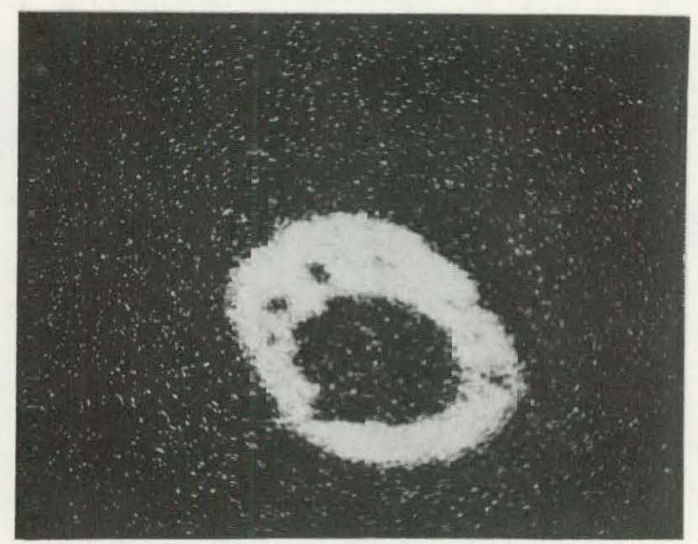

NdLa

Fig. 21. Retention of Rare-Earth Fission Products in the Kernel of a Sol-Gel $\mathrm{UO}_{2} \mathrm{Tr}_{-}$so-Coated Particle Irradiated in $\mathrm{HR} 3-8$. 


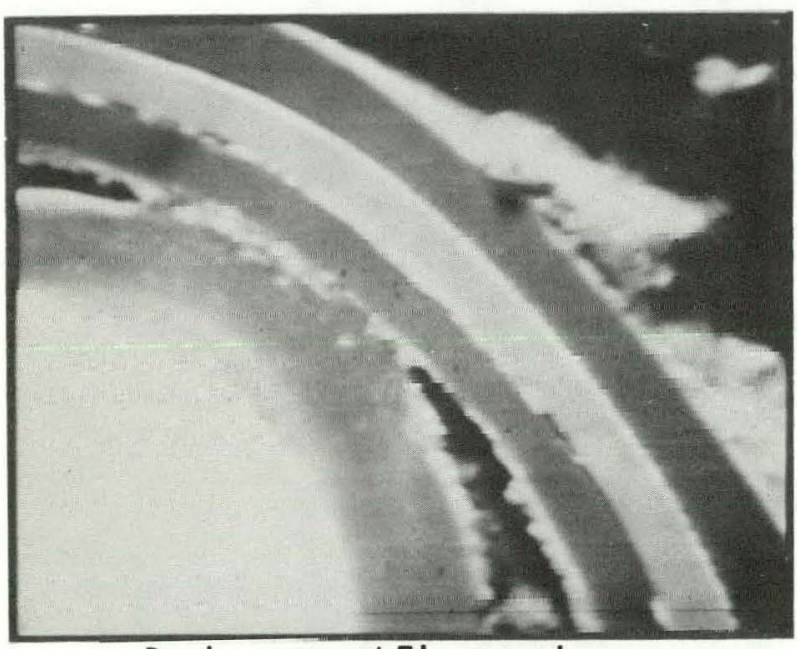

Backscattered Electron Image

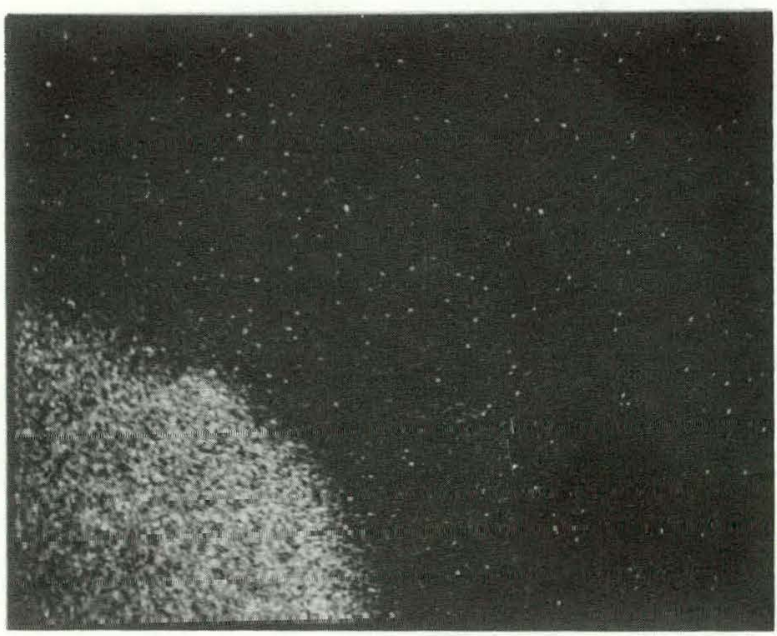

$\mathrm{U} M \beta$

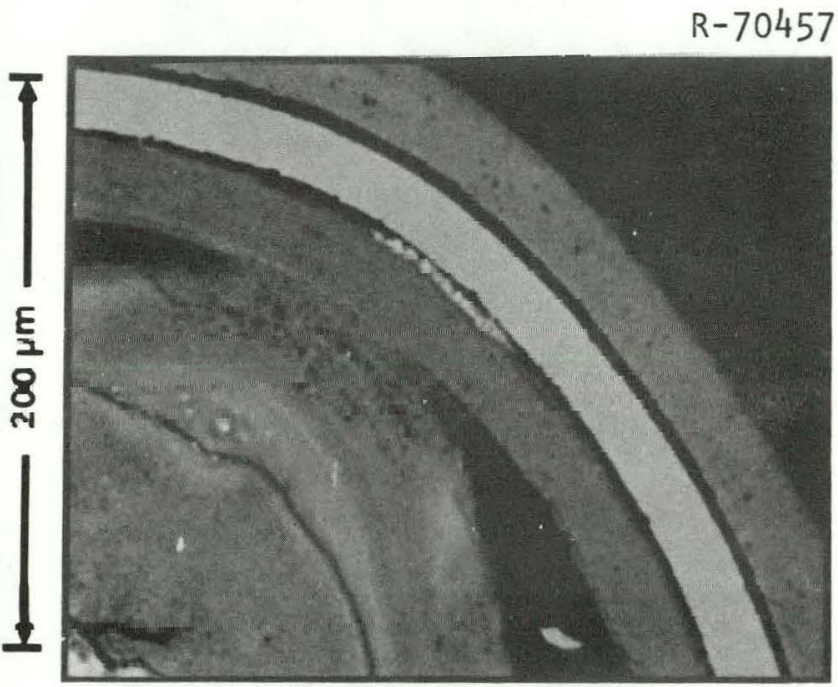

Optical Micrograph

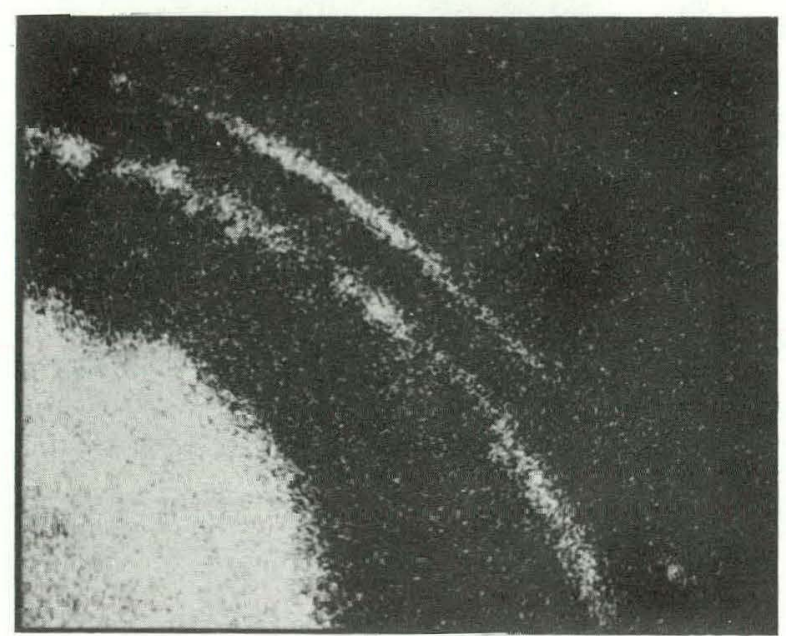

Nd La

Fig. 22. Distribution of Uranium and Rare-Earth Fission Products (Typified by Neodymium X-Ray Display) in a 50\%-Converted Weak-Acid-ResinDerived Particle. Note neodymium has reached the inner surface of the silicon carbide coating. The neodymium display is representative of the other products cesium, praseodymium, and lanthanum. 


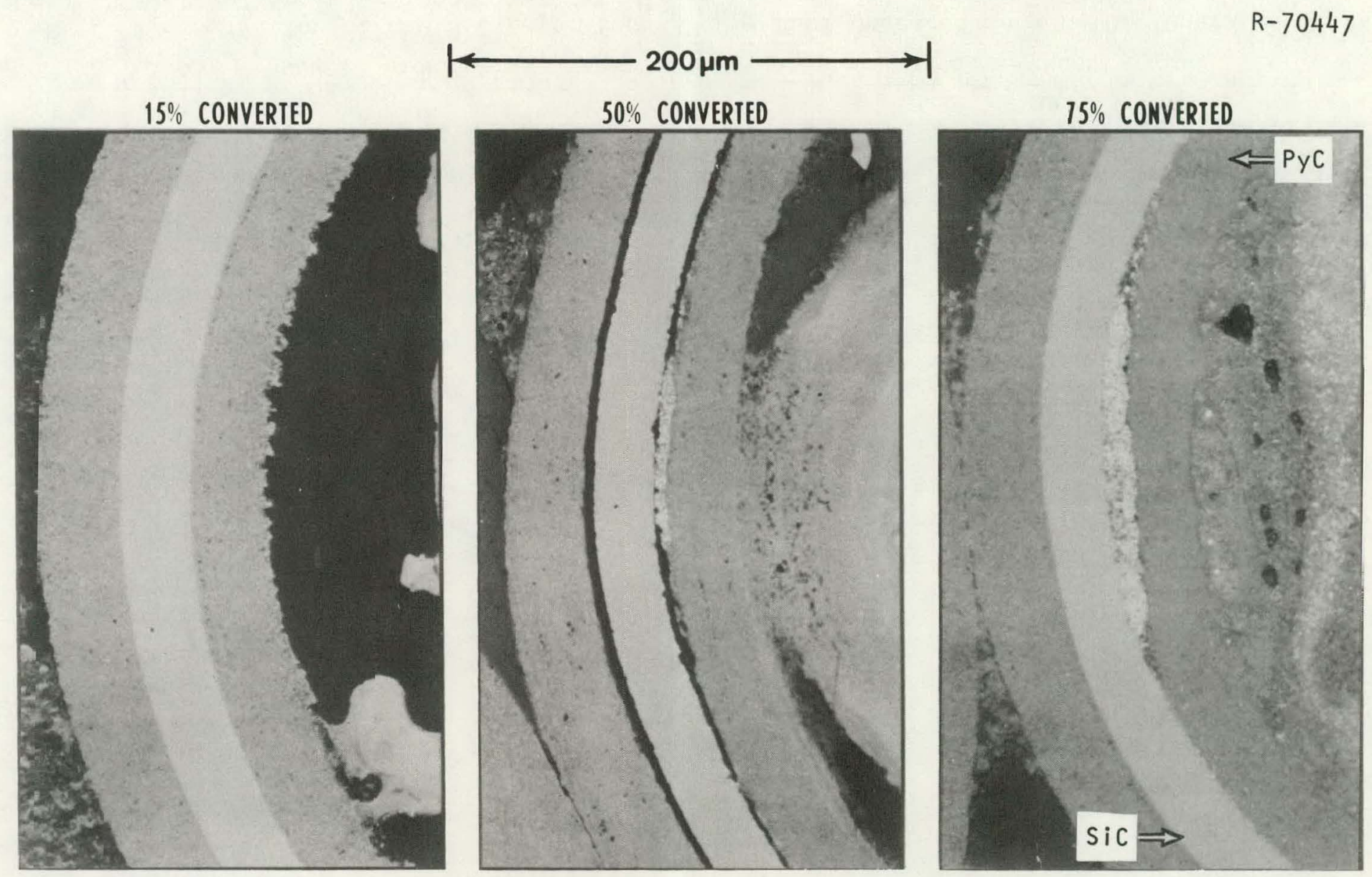

Fig. 23. Accumulation of Rare-Earth Fission Products at the Silicon Carbide Inner Pyrolytic Carbon Inter of fission products in the coating of the $15 \%$-converted kernel. 

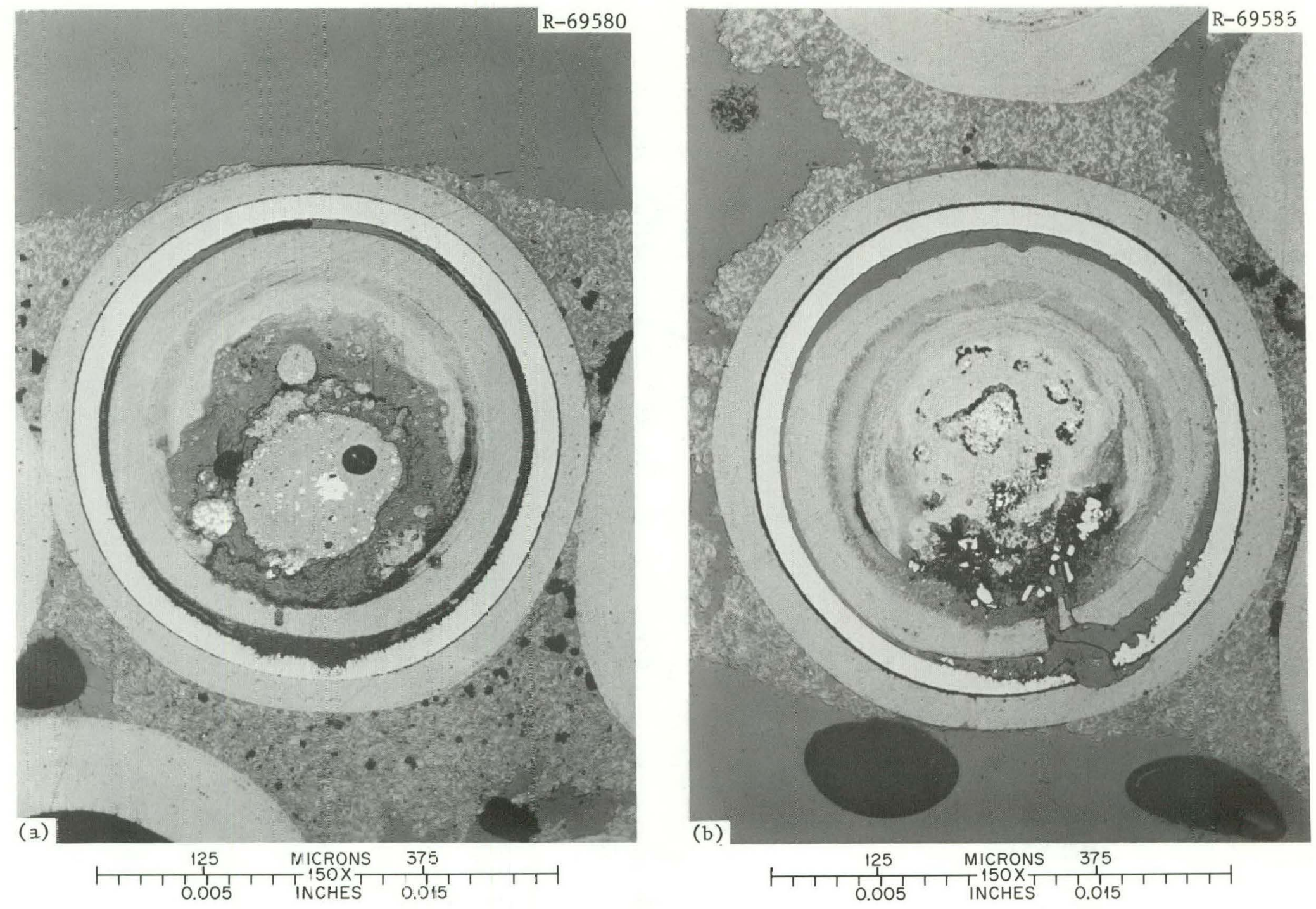

Fig. 24. Oxidation of the SiC Layer for WAR UO $\mathrm{U}_{2}$ Fuel Operated in HRB-10. Operated on (a) sirface of fuel rod at about $=250^{\circ} \mathrm{C}$ anc (b) center o fuel rod at about $1500^{\circ} \mathrm{C}$. 
By the current definition of failure developed for dense fissile kernels this fuel would be unacceptable; however, this definition of failure is not appropriate for WAR fuels. For fissile particles containing dense oxide kernels that are migrating up the temperature gradient, migration through the buffer layer means that the integrity of the pressure vessel has been compromised. Thus, failure is defined as migration through the buffer layer. However, for fissile particles containing WAR $\mathrm{UO}_{2}-\mathrm{UC}_{2}$ kernels with more than $15 \%$ carbide phase, temperature-gradient-dependent migration of the kernel has not been observed. The incorporation of the buffer layer into the kernel does not appear to influence the integrity of the outer coating layers. Irradiation testing is in progress to determine if the $15 \%$-converted WAR fuel meets the performance criteria for fissile particles (less tha $0.7 \%$ failure during irradiation to full large HTGR exposure). Quantitative electron microprobe results have shown that the $15 \%-$ converted kernels retain all but about $12 \%$ of the rare-earli fission products that form during irradiation. Quantitative work is in progress for kernels of 50 and $75 \%$ conversion; from the optical comparisons that have already been made, we believe that these fuels will release more fission products than the $15 \%$-converted fuel.

\section{THERMODYNAMIC ANALYSIS}

-

The previous section emphasized the importance of fission product attack of the inner low-temperature isotropic and silicon carbide layers, and the qualitative relationship between the amount of $\mathrm{UO}_{2}$ phase present in the WAR kernel and the extent of attack observed. For processing it is desirable to maximize the amount of $\mathrm{UO}_{2}$ present. Also, the manufacturer would like to have as much latitude as possible on the compositional requirements. Irradiation testing has suggested that WAR fuel between 15 and $75 \%$ converted from oxide to carbide will perform successfully, although there is some concern over the extent of fission product attack observed for the $75 \%$-converted fuel. Thermodynamic analysis of the chemical system present in WAR fissile kernels suggests a lower limit of $15 \%$ conversion and an upper limit of about $70 \%$.

The thermodynamic explanation of the observed irradiation phenomena is based on the chemical potential of oxygen $\left(\mu_{2}\right)$ for the fuel and fission-product equilibria. Here $\mu_{\mathrm{O}_{2}}$ is defined as $R T \ln P_{\mathrm{O}_{2}}$, in which $R=8.314 \mathrm{~J} \mathrm{~mole}^{-1} \mathrm{~K}^{-1}\left(1.987 \mathrm{cal} \mathrm{mole} \mathrm{K}^{-1}\right), T$ is temperature in $\mathrm{K}$, and $P_{\mathrm{O}_{2}}$ is in atmospheres, with $P_{\mathrm{O}_{2}}$ in the standard state at 1 atm (1 atm $=0.1013 \mathrm{MPa}$ ).

The $\mu_{\mathrm{O}_{2}}$ values have been calculated as a function of temperature for the probable oxide-carbide equilibria for uranium and each fission product. Typical equilibria are $\mathrm{UO}_{2}+1.86 \mathrm{C} \rightarrow \mathrm{UC}_{1.86}+\mathrm{O}_{2}, 2 \mathrm{SrO}+4 \mathrm{C} \rightarrow$ $2 \mathrm{SrC}_{2}+\mathrm{O}_{2}$, and $1.33 \mathrm{LaO}_{1.5}+2.66 \mathrm{C} \rightarrow 1.33 \mathrm{LaC}_{2}+\mathrm{O}_{2}$. Activity effects resulting from solution of fission-product oxides (primarily in $\mathrm{UO}_{2}$ ) 
were not considered because quantitative activity data are not available. The results of these calculations are given in $\mathrm{Fig} .25$; the $\mathrm{SiO}_{2}-\mathrm{C}-\mathrm{SiC}-\mathrm{O}_{2}$ equilibrium is also shown because of the silicon carbide presence in Triso coatings. The $\mu_{\mathrm{O}_{2}}$ values of the various equilibria below $800 \mathrm{~K}$ establishes the following ranking in terms of increasing stability of the oxide versus the carbide: $\mathrm{Ba}, \mathrm{Zr}, \mathrm{Eu}, \mathrm{Sr}, \mathrm{U}, \mathrm{Sm}, \mathrm{La}, \mathrm{Pr}, \mathrm{Nd}$, Ce, and $\mathrm{Y}$. In other words, as $\mu_{\mathrm{O}_{2}}$ is made more negative, the first to form will be $\mathrm{BaC}_{2}$ instead of $\mathrm{BaO}$, followed by $\mathrm{ZrC}$ instead of $\mathrm{ZrO}$, and so on.

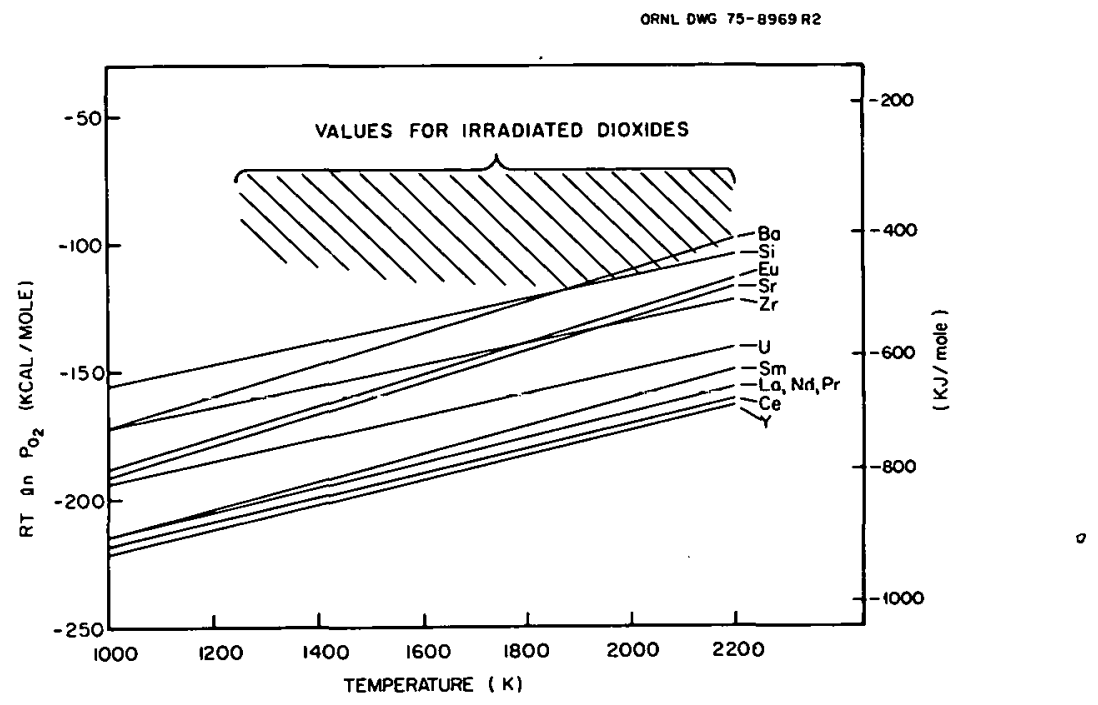

Fig. 25. Oxygen Potential vs Temperature for Various Oxide-Carbide Equilibria in the WAR $\mathrm{UO}_{2}-\mathrm{UC}_{2}$ System. Also shown are experimental $\mathrm{UO}_{2}$ values for irradiated HTGR oxide fuels.

This report is concerned primarily with the effect of the $\mathrm{UC}_{2}-\mathrm{UO}_{2}-$ $\mathrm{C}-\mathrm{O}_{2}$ equilibrium on the thermodynamics of the WAR HTGR fuel. As long as both $\mathrm{UC}_{2}$ and $\mathrm{UO}_{2}$ are present, then Fig. 25 demonstrates that $\mathrm{Ba}, \mathrm{Zr}$, $\mathrm{Eu}, \mathrm{Sr}$, and $\mathrm{Si}$ will be present as carbides, while Y, La, and all the rareearth fission products except for europium will be present as oxides; europium is present as $\mathrm{EuC}_{2}$. Another important effect of the $\mathrm{UC}_{2}-\mathrm{UO}_{2}-$ $\mathrm{C}-\mathrm{O}_{2}$ equilibrium is the reaction of the $\mathrm{UC}_{2}$ with oxygen that is released by the fissioning of ${ }^{235} \mathrm{UO}_{2}$ and that is not combined with oxide-forming fission products. At the $\mu_{\mathrm{O}_{2}}$ of the $\mathrm{UO}_{2}-\mathrm{UC}_{2}$ system there is no interaction of the lanthanum, yttrium, or rare-earth sesquioxides [ $\left.(\mathrm{RE}) \mathrm{O}_{\frac{1}{5}} 5\right]$
with $\mathrm{UO}_{2}$ that would increase the oxygen/uranium ratio above two. $21,2{ }^{2}$ with $\mathrm{UO}_{2}$ that would increase the oxygen/uranium ratio above two.
Then the usual mass-balance calculations ${ }^{23}, 24,25$ demonstrate that each ${ }^{235} \mathrm{UO}_{2}$ fission leads to fission-product oxides that combine with only about 1.62 oxygen atoms even if one temporarily assumes that $\mathrm{Ba}, \mathrm{Zr}$, $\mathrm{Eu}$, and $\mathrm{Sr}$ were to form oxides; this leaves 0.38 oxygen atom per fission that would combine with unfissioned $\mathrm{UC}_{2}$ to form $\mathrm{UO}_{2}$. It should also be noted that cesium and rubidium will not be present as oxides; the $\mu_{O_{2}}$ values of the $\mathrm{UO}_{2}-\mathrm{UC}_{2}$ system are much lower than those necessary for the stability of the uranates and molybdates of cesium and rubidium. ${ }^{26}$ 
Now consider a fuel particle at $75 \%$ FIMA in view of the above information and the fission-product yields for ${ }^{235} \mathrm{U}$ in a thermal flux. ${ }^{27}$ For example, for the reaction (not an equilibrium) $2 \mathrm{C}+2 \mathrm{BaO}+\mathrm{UC}_{2} \rightarrow$ $\mathrm{UO}_{2}+2 \mathrm{BaC}_{2}$, the initial amount of $\mathrm{UC}_{2}$ required to maintain all barium as $\mathrm{BaC}_{2}$ instead of $\mathrm{BaO}$ at $75 \%$ FIMA is ( $7.0 \% \mathrm{Ba} / \mathrm{fission}$ ) (0.75 fission) $\left(\mathrm{UC}_{2} / 2 \mathrm{BaO}\right)=2.6 \% \mathrm{UC}_{2}$. Such calculations lead to the $\mathrm{UC}_{2}$ requirements shown in Table 4. Thus, for an initial $\mathrm{UC}_{2}$ content of $39.9<\mathrm{UC}_{2}<16.9$ in the $\mathrm{UO}_{2}-\mathrm{UC}_{2}$ kernel, at $75 \%$ FIMA no $\mathrm{UC}_{2}$ would be present, barium would be present as $\mathrm{BaC}_{2}$ and zirconium would be present as $\mathrm{ZrO}_{2}$ and $\mathrm{ZrC}$. $\mathrm{All}$ other fission products listed in Table 4 would be present as oxides along with the residual $25 \% \mathrm{UO}_{2}$ that did not fission.

Table 4. Calculated Initial $\mathrm{UC}_{2}$ Amounts for Indicated Results at $75 \%$ FIMA

\begin{tabular}{|c|c|c|}
\hline \multirow{2}{*}{ Purpose of $\mathrm{UC}_{2}$ Addition } & \multicolumn{2}{|c|}{ Initial $\mathrm{UC}_{2}$ Required, \% } \\
\hline & For Each & Cumulative \\
\hline $\mathrm{UO}_{2}$ instead of high $P_{\mathrm{CO}}$ & 14.3 & 14.3 \\
\hline $\mathrm{BaC}_{2}$ instead of $\mathrm{BaO}$ & 2.6 & 16.9 \\
\hline $\mathrm{ZrC}$ instead of $\mathrm{ZrO}_{2}$ & 23 & 39.9 \\
\hline $\mathrm{EuC}_{2}$ instead of $\mathrm{EuO}_{1.5}$ & 0.4 & 40.3 \\
\hline $\mathrm{SrC}_{2}$ instead of Sro & 3.3 & 43.6 \\
\hline $\mathrm{UC}_{2}$ instead of $\mathrm{UO}_{2}$ & 25 & 68.6 \\
\hline $\mathrm{SmC}_{2}$ instead of $\mathrm{SmO}_{1.5}$ & 1.7 & 70.3 \\
\hline$(\mathrm{La}, \mathrm{Nd}, \mathrm{Pr}) \mathrm{C}_{2}$ instead of $(\mathrm{La}, \mathrm{Nd}, \mathrm{Pr}) \mathrm{O}_{1,5}$ & 18 & 88.3 \\
\hline $\mathrm{CeC}_{2}$ instead of $\mathrm{CeO}_{1.5}$ & 9.2 & 97.5 \\
\hline $\mathrm{YC}_{2}$ instead of $\mathrm{YO}_{1.5}$ & 2.3 & $99.8(\sim 100 \%)$ \\
\hline
\end{tabular}

It is important to note that the phases present depend on the extent of burnup as well as on the initial $\mathrm{UC}_{2}$ content (Fig. 26). The results at an initial $20 \% \mathrm{UC}_{2}$ content exemplify this relationship. Both $\mathrm{UC}_{2}$ and $\mathrm{UO}_{2}$ are initially present, and these phases establish the $\mathrm{H}_{2}$ up to about 34\% FIMA. Fission-product systems at the more negative $\mu_{\mathrm{O}_{2}}$ values (Fig. 25) are oxides, while those at more positive values are carbides. During fission to $34 \% \mathrm{FIMA}$, the $\mathrm{UC}_{2}$ content is decreasing because it is reacting with oxygen that is released by the fissioning of the $\mathrm{UO}_{2}$; this released oxygen would otherwise form $\mathrm{ZrO}_{2}, \mathrm{SrO}, \mathrm{BaO}$, and $\mathrm{EuO}_{1}, 5$, as well as $0.38 \mathrm{CO}$ per fission. Once burnup exceeds about $34 \%$ FIMA, $\mathrm{UC}_{2}$ has disappeared and the next oxide-carbide equilibrium, $\mathrm{SrO}-\mathrm{SrC}_{2}-\mathrm{C}-\mathrm{O}_{2}$, establishes the $\mu_{\mathrm{O}_{2}}$ for the system up to about $38 \%$ FIMA. 


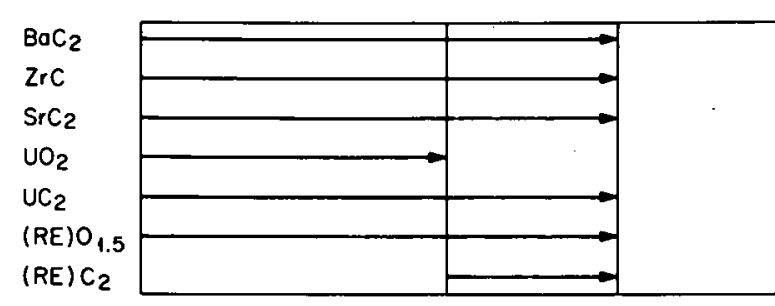

ORNL DWG 75-5356

INITIAL KERNEL

COMPOSITION (\%)

\begin{tabular}{ll}
$\mathrm{UO}_{2}$ & $\mathrm{UC}_{2}$ \\
\hline 20 & 80
\end{tabular}

4060
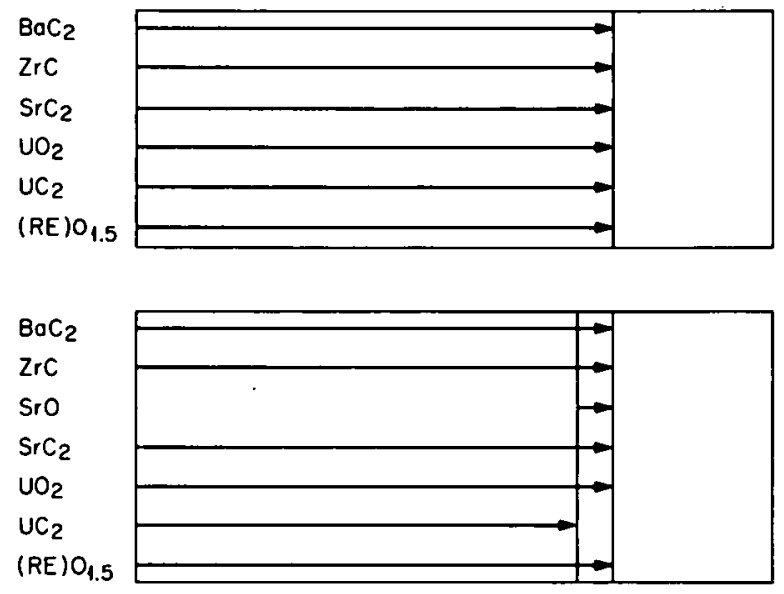

$60 \quad 40$

8020
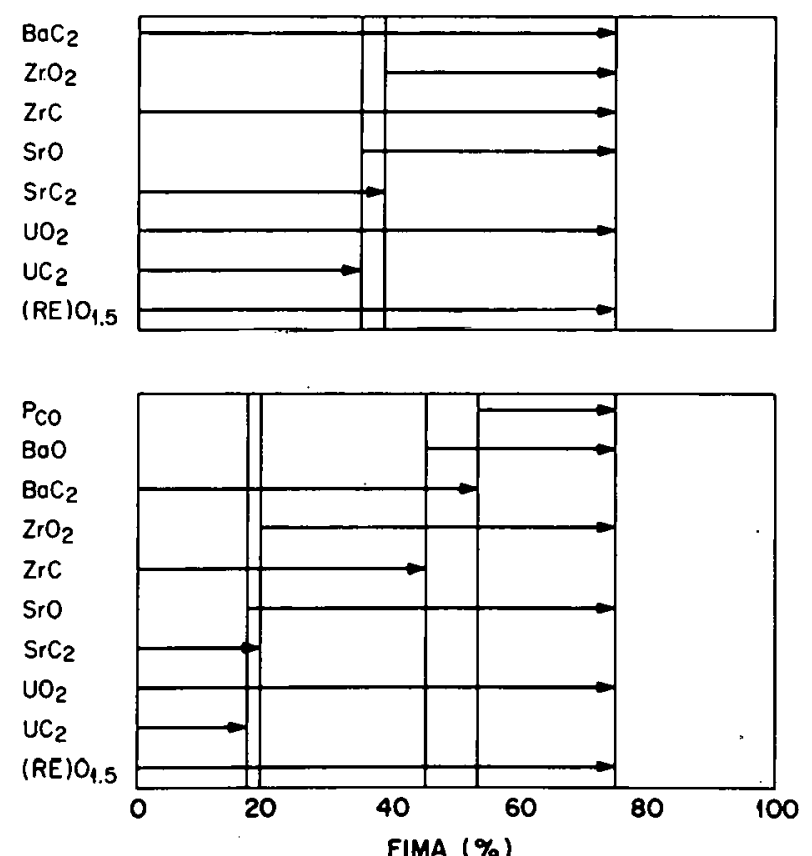

$90 \quad 10$

Fig. 26. Phases Present in a Fully Enriched $\mathrm{UO}_{2}-\mathrm{UC}_{2}$ Kernel as a Function of ${ }^{235} \mathrm{U}$ Burnup and Initial $\mathrm{UC}_{2}$ Content. The $\mathrm{EuO}_{1.5}-\mathrm{EuC}_{2}$ system is not shown because it has a small ( $<1 \%)$ yield. However, its chemical behavior is different from the other lanthanides and it converts from the carbide to the oxide at about the same burnup as does the strontium. 
The $\mathrm{SrC}_{2}$ is completely converted to Sro at about 38\% FIMA. After the trace of $\mathrm{EuC}_{2}$ is converted to $\mathrm{EuO}_{1.5}$ the $\mathrm{ZrO}_{2}-\mathrm{ZrC}-\mathrm{C}-\mathrm{O}_{2}$ equilibrium is then established and maintained to $75 \%$ FIMA.

Consideration of the data in Table 4 and Fig. 25 leads to a thermodynamic rationalization of the observed rare-earth behavior in the WAR $\mathrm{UO}_{2}-\mathrm{UC}_{2}$ fuel system. As long as the initial $\mathrm{UC}_{2}$ percentage is less than $68.6 \%$, al1 rare-earth elements (RE) except europium will be present as sesquioxides. These oxides remain in the kernel as illustrated above. When the initial $\mathrm{UC}_{2}$ percentage exceeds $68.6 \%$, then the rare-earth elements form dicarbides and the highest possible pressures of rareearth neutral gases $\left(P_{\mathrm{RE}}\right)$; the presence of these dicarbides and $P_{\mathrm{RE}}$ are apparently associated with the silicon carbide interactions described. earlier. The decreasing amount of rare-earth elements (RE) at the silicon carbide interface with the initial $\mathrm{UO}_{2}$ amount of more than $68.6 \%$ may result from the equilibrium

$$
(\mathrm{RE}) \mathrm{O}_{1.5} \rightarrow(\mathrm{RE})_{g}+0.75 \mathrm{O}_{2}
$$

As the $\mathrm{UO}_{2}$ content is increased, the $\mu_{\mathrm{O}_{2}}$ and thus the $P_{\mathrm{O}_{2}}$ is increased, with a decrease in $P_{\mathrm{RE}}$.

Initial $\mathrm{UC}_{2}$ contents from 14.3 to $68.6 \%$ are apparently acceptable since no silicon carbide-degrading reactions have yet been observed in the irradiations.

Other potentially damaging effects occur for initial $\mathrm{UC}_{2}$ percentages below 14.3\%. The fission-released oxygen - as much as the 0.38 oxygen atom per fission mentioned earlier - reacts with a minor amount of the carbon in the particle to form carbon monoxide. [The carbon monoxide amounts are equivalent to the maximum of $0.31(\mathrm{Kr}+\mathrm{Xe})$ per ${ }^{235} \mathrm{U}$ fission.] If the inner LTI layer fails, the carbon monoxide will react with silicon carbide to form $\mathrm{SiO}_{2}$, maintain the carbon monoxide pressure at that for the $\mathrm{SiC}-\mathrm{SiO}_{2}-\mathrm{C}-\mathrm{CO}$ equilibrium (Fig. 25) and lead to failure of the silicon carbide layer. Thus, from thermodynamic considerations, the $14.3 \%$ initial $\mathrm{UC}_{2}$ addition appears to be the minimum desirable amount.

\section{DISCUSSION AND SUMMARY}

Two important fuel failure mechanisms have been identified and appear to be directly related to fuel kernel chemical composition. These mechanisms are thermal migration (amoeba) of the fuel kernels up the temperature gradient and through the coatings and chemical interaction of fission products with the silicon carbide layer of Triso particles. Amoeba, which is a severe problem with dense oxide kernels, has not been a performance limiting problem with carbide fuels 
in the temperature and temperature gradient regions of interest for the HTGR. Amoeba has not been observed in the WAR fuels containing more than $15 \% \mathrm{UC}_{2}$ in $\mathrm{UO}_{2}$. Also, chemical interaction, a severe problem for dense carbide fuels, has been controlled in WAR fuels by controlling their composition.

Thermodynamic considerations suggest that kernel compositions ranging from 15 to $70 \%$ conversion from oxide to carbide should perform well. In kernels with less than $15 \%$ carbide the fission released oxygen, will react with carbon to form carbon monoxide, which will raise the internal gas pressure and perhaps contribute to thermal migration. Should the carbon monoxide reach the silicon carbide layer, because of the failure of the inner LTI or because of a permeable inner LTI, the carbon monoxide will react with the silicon carbide to form $\mathrm{SiO}_{2}$, and ultimately cause the silicon carbide layer to fail. In kernels with more than $70 \%$ carbide, insufficient oxygen is present to oxidize and thus stabilize the chemically active rare earth fission products, which will distill out of the kernel as carbides and attack the silicon carbide and inner LTI layers. Irradiation testing to date supports the conclusions of the thermodynamic studies. Compositions of $0,15,50$, 75 , and $100 \%$ carbide (the remainder oxide) have been tested. The WAR $\mathrm{UO}_{2}$ fuel exhibited excessive thermal migration. The WAR $\mathrm{UC}_{2}$ fuel exhibited excessive fission product attack of the silicon carbide layer, causing a high failure fraction in these particles. The 15, 50, and $75 \%$ carbide kernels performed well with increasing fission product attack of the silicon carbide evident with increasing carbide content.

The kernel process development work done so far indicates that the flexibility expected of WAR fuel, with repsect to kernel density and composition, is indeed possible in laboratory-scale equipment. The technology appears to be capable of extrapnlation to production scale equipment with no difficulty. Additional work on process development will continue to determine process latitudes.

The importance of this work is that a fissile fuel has been developed suitable for any HTGR application currently under consideration, up to irradiation temperatures of $1400^{\circ} \mathrm{C}$. Probably, additional irradiation testing of optimum compositions will. push this temperature limit still higher. Further, the processes required to produce these particles are readily adaptable to remote operation, which is essential for a recycle fuel. Direct comparisons of the WAR fuel with the current reference fresh fuel (dense $\mathrm{UC}_{2}$ ) suggest superior performance by the WAR fuel, which further suggests that the WAR fuel could eventually become the reference fresh fissile fuel as well as the reference recycle fuel.

Future work should be directed at optimizing the WAR particle design and developing a product specification for manufacture. The fuel rod and fuel element designs need improvement to take advantage of the performance capabilities of the coated particles. Design modifications 
that minimize the temperature difference between kernels and coolant will permit higher coolant temperatures and higher thermal efficiency to permit the HTGR to satisfy the needs for steam-cycle power production and process heat applications.

\section{ACKNOWLEDGMENTS}

The authors wish to acknowledge the contributions of many people in the areas of planning, execution, and evaluation of the numerous irradiation experiments that have been cited in this report. In particular, the authors wish to acknowledge W. P. Eatherly of the Metals and Ceramics Division and B. H. Montgomery of the Engineering Technology Division for their participation in the planning and design of the experiments; R. L. Hamner, J M Robbins, W. J. Lackey, G. W. Weber, W. H. Miller, Jr., C. Hamby, D. E. Rosson, J. B. Flynn, M. D. Allen, and C. E. DeVore of the Metals and Ceramics Division for fabrication and characterization of the fuel specimens; and H. T. Kerr of the Engineering Technology Division and R. L. Shepard of the Instrumentation and Controls Division for dosimetry and instrumentation, respectively. Postirradiation examination was conducted by E. L. Ryan, N. M. Atchley, L. G. Shrader, and T. J. Henson of the Metals and Ceramics Division. The authors also acknowledge the assistance of G. W. Griffith for technical editing and Julia Bishop for typing and makeup of the manuscript. We are particularly indebted to G. W. Weber and A. R. Olsen for their excellent technical reviews and many helpful comments.

\section{REFERENCES}

1. B. H. Montgomery, J M Robbins, and R. L. Hamner, "Irradiation Tests in HFIR Removable Beryllium Facility," Gas-Cooled Reactor Programs Annu. Prog. Rep. Dec. 31, 1973, ORNL-4975, pp. 89-127.

2. Preliminary Safety Analysis Report for Fulton Generating Station, Chapter 4.

3. T. B. Lindemer and R. L. Pearson, Kermel Migration for HTGR Fuels from the Th-U-C-O-N System, ORNL/TM-5207 (April 1976).

4. 0. M. Stansfield, C. B. Scott, and J. Chin, "Kernel Migration in Coated Carbide Fuel Particles," Nucl. Technol. 25: 517-30 (1975).

5. Oak Ridge National Laboratory and Gulf General Atomic, National HTGR Fuel. Recycle Development Progron Plan, ORNL-4702 (August 1971) p. 16 .

6. J. L. Scott et al., An Irradiation Test of Bonded HTGR Coated Particle Fuels in an Instrumented Capsule in HFIR, ORNL-TM-3460 (March 1972). 
7. R. A. Olstad et al., An Irradiation Test of Candidate HTGR Recycle Fuels in the H-1 and H-2 Capsules, ORNL-TM-4397 (July 1974, Addendum April 1975).

8. K. H. Valentine et al., Irradiation Performance of HTGR Fuel Rods in HFIR Experiments $H R B-7$ and -8 , report in preparation.

9. F. E. Clark, "Ion Exchange Resin Fuel Beads," Nerva Fuel Element Dev. Prog. Sum. Rep. July 1966-June 1972, Y-1852 (1973) part 5.

10. M. D. Silverman and C. B. Pollock, "Resin Fuel Particles for HighTemperature Gas-Cooled Reactors," pp. 245-46 in 11th Bienn. Conf. Carbon, Gatlinburg, Tenn., June 4-6, 1973, CONF. 730601.

11. P. A. Haas, HTGR Fuel Development: Use of $\mathrm{UO}_{3}$ to Load Cation Exchange Resin for Microsphere Preparation, ORNL-TM-3817 (1972).

12. K. J. Notz et a1., BuZZ. Am. Cercm. Soc. 53(8): 621 (1974).

13. R. L. Beatty (abstract), BuZZ. Am. Ceram. Soc. 53(4): 363 (1974).

14. R. L. Beatty and E. L. Long, Jr., "Preparation and Performance of Coated Particle Nuclear Fuels Having $\mathrm{UC}_{x} \mathrm{O}_{y}$ Kernels," pp. 315-16 in 12th Bienn. Conf. Carbon Extended Abstracts and Program, July 28August 1, 1975, Pittsburgh, Pennsylvania. Cosponsored by the American Carbon Society and the School of Engineering, University of Pittsburgh.

15. T. B. Lindemer, "Rate-Controlling Factors in the Carbothermic Synthesis of Advanced Fuels," Nucl. Appl. Technol. 9(5): 711-15 (November 1970).

16. F. J. Homan et al., Trradiation Performance of HTGR Fuel Rods in HFIR Experiments HRB-4 and -5, ORNL-5115 (June 1976).

17. K. H. Valentine et al., Irradiation Performance of HTGR Fuel Rods in HFIR Experiments $H R B-7$ and -8 , report in preparation.

18. F. J. Homan et al., Irradiation Performance of HTGR Fuel Rods in $H F I R$ Experiments $H R B-9$ and -10 , report in preparation.

19. E. L. Long, Jr., et a1, Fabrication of ORNL Fuel Irradiated in the Peach Bottom Reactor and Postirradiation Examination of Recycle Test Elements 7 and 4, ORNL-TM-4477 (September 1974).

20. R. A. Bradley et al., "Fuel Stick Fabrication," Gas-Cooled Reactor and Thorium Utilization Programs Annu. Prog. Rep. Sept. 30, 1971, ORNL-4760, pp. 52-55.

21. T. L. Markin and E. C. Crouch, "Thermodynamic Data for U-Ce Oxides," J. Inorg. Nucl. Chem. 32: 77-82 (1970). 
22. J. F. Wadier, Phase Diagram and Thermodynamic Properties of the Uranium-Neodymium-Oxygen System, CEA-R-4507 (November 1973), p. 59.

23. R. H. Flowers and G. W. Horsley, The Influence of Oxide Kernels on the Manufacture and Performance of Coated Particle Fuel, AERE-R5949, (1968).

24. J. M. Leitnaker, "Applications of Thermodynamics for Predicting and Understanding the Performance of Fast Breeder Reactor Oxide Fuels," J. Nucl. Mater. 51: 95-105 (1974).

25. T. B. Lindemer and H. J. de Nordwa11, An Analysis of Chemical Failure of Coated $\mathrm{UO}_{2}$ and Other Oxide Fuels in the High-Temperature Gas-Cooled Reactor, ORNL-4926 (1974).

26. M. J. Kania et al., Irradiation Performance of HTGR Fertile Fuel in HFIR Target Capsules HT-12 to 15: Part I - Experiment Description and Fission Product Behavior, ORNL/TM-5305 (in press).

27. M. E. Meek and B. F. Rider, Compilation of Fission Product Yields, NEDO-12154 (1972). 
THIS PAGE

WAS INTENTIONALLY LEFT BLANK 
ORNL/TM-5602

Distribution

Category UC-77.

\section{INTERNAL DISTRIBUTION}

1-3. Central Research Library

4. Document Reference Section

5-14. Laboratory Records Department

15. Laboratory Records, ORNL RC

16. ORNL Patent office

17. R. L. Beatty

18. R. A. Bradley

19. A. .T. Caputo

20. J. A. Conlin

21. J. H. Coobs

22. D. Costanzo

23. F. L. Culler

24. W. P. Eatherly

25. R. B. Evans III

26. R. L. Hamner

27. R. F. Hibbs

28-30. M. R. Hill

31-34. F. J. Homan

35. D. R. Johnson
36. M. J. Kania

37-38. P. R. Kasten

39. H. T. Kerr

40. W. J. Lackey

41. T. B. Lindemer

42-44. E. L. Long, Jr.

45. R. K. Kibbe

46. A. L. Lotts

47. C. S. Morgan

48. M. T. Morgan

49. K. J. Notz

50. R. L. Pearson

51. W. H. Pechin

52. H. Postma

53. J M Robbins

54. R. L. Shepard

55. T. N. Tiegs

56. K. R. Thoms

57. J. R. Weir, Jr.

EXTERNAL DISTRIBUTION

58-65. ERDA DIVISION OF NUCLEAR FUEL CYCLE AND PRODUCTION, Washington, DC 20545
Director (2)
R. G. Bradley (1)
W. S. Schieb (5)

66-67. ERDA DIVISION OF REACTOR NUCLEAR RESEARCH AND APPLICATIONS,

Washington, DC 20545

Director

68-69. ERDA IDAHO OPERATIONS OFFICE, P.0. Box 2108, Idaho Falls, ID 83401

C. E. Williams, Manager

Rarry Smith

70. ERDA OFFICE OF PROGRAM MANAGEMENT, RESEARCH AND SPACE PROGRAMS, P.0. Box 81325, San Diego, CA 92138

J. B. Radcliffe 
EXTERNAL DISTRIBUTION (Continued)

71. ERDA SAN FRANCISCO OPERATIONS OFFICE, 1333 Broadway, Wells Fargo Building, Oakland, CA 94612

R. D. Thorne, Manager

72-74. ERDA OAK RIDGE OPERATIONS OFFICE, P.O. Box E, Oak Ridge, TN 37830

Director, Research and Technical Support Division

Director, Reactor Division

F. E. Dearing, Reactor Division

75-245. ERDA TECHNICAL INFORMATION CENTER, P.0. Box 62, Oak Ridge, TN 37830

For distribution as shown in TID-4500 Distribution Category, UC-77 (Gas-Cooled Reactor Technology).

246-253. ERDA Exchange Agreements with Germany and Dragon Project. 